\title{
Bibliografia historii wychowania, szkolnictwa i myśli pedagogicznej w Polsce za rok 2004
}

W bibliografii zarejestrowano druki zwarte oraz artykuły z czasopism i prac zbiorowych opublikowanych w 2004 r. Zamieszczono w niej także pozycje $z$ lat wcześniejszych, które nie znalazły się w bibliografii za poprzednie lata. W przypadkach koniecznych opis uzupełniono adnotacjami. Pozycje w bibliografii ułożono wedhug podanego niżej schematu.

I. Opracowania ogólne. Bibliografie

II. Rozwój oświaty, wychowania i myśli pedagogicznej

1. Opracowania ogólne

2. Okres do 1795 roku

3. Okres $1795-1918$

4. Okres 1918-1939

5. Okres $1939-1945$

6. Okres $1945-1989$

7. Okres 1989-2004

8. Oświata polonijna

III. Dzieje szkół różnych stopni

9. Szkoły podstawowe i zakłady wychowawcze

10. Szkoły średnie ogólnokształcące

11. Szkoły zawodowe

12. Zakłady kształcenia nauczycieli (z wyjątkiem szkół wyższych)

13. Szkoły wyższe

IV. Biografie

14. Zbiory życiorysów

15. Poszczególne biografie

V. Dzieje oświaty pozaszkolnej

16. Oświata dorosłych

17. Biblioteki

VI. Dzieje ruchu nauczycielskiego

18. Opracowania ogólne

19. Pamiętniki nauczycieli

VII. Z życia i dzialalności organizacji młodzieżowych 


\section{WYKAZ SKRÓTÓW CZASOPISM}

Acta UNC - Acta Universitatis Nicolai Copernici

Acta Univ. Wr. - Acta Universitatis Wratislaviensis

Arch. Bibl. i Muzea Kośc. - Archiwa, Biblioteki i Muzea Kościelne

Arch. Hist. i Filoz. Med. - Archiwum Historii i Filozofii Medycyny

Białorus. Zesz. Hist. - Białoruskie Zeszyty Historyczne

Biul. Hist. Szt. - Biuletyn Historii Sztuki

Biul. Hist. Wych. - Biuletyn Historii Wychowania

Biul. Ukr. - Biuletyn Ukrainoznawczy

Czasop. Prawno-Hist. - Czasopismo Prawno-Historyczne

Częst. Studia Teol. - Częstochowskie Studia Teologiczne

Fol. Hist. Crac. - Folia Historica Cracoviensia

Kom. Inst. Bałt. - Komunikaty Instytutu Bałtyckiego

Kom. Mazur.-Warm. - Komunikaty Mazursko-Warmińskie

Krak. Rocz. Archiw. - Krakowski Rocznik Archiwalny

Kutn. Zesz. Reg. - Kutnowskie Zeszyty Regionalne

Kwart. Hist. Nauki i Tech. - Kwartalnik Historii Nauki i Techniki

Kwart. Hist. Żydów - Kwartalnik Historii Żydów

Kwart. Pedag. - Kwartalnik Pedagogiczny

Lub. Rocz. Pedag. - Lubelski Rocznik Pedagogiczny

Misc. Hist.-Iur. - Miscellanea Historico-Iuridica

Nauki Hum. - Nauki Humanistyczne

Pam. Ciesz. - Pamiętnik Cieszyński

Pam. TMZK - Pamiętnik Towarzystwa Miłośników Ziemi Kościańskiej

Pr. Hist.-Archiw. - Prace Historyczno-Archiwalne

Prz. Hist. - Przegląd Historyczny

Prz. Hist.-Ośw. - Przegląd Historyczno-Oświatowy

Prz. Morski - Przegląd Morski

Prz. Pol. - Przegląd Polonijny

Przyj. Ludu - Przyjaciel Ludu

Rocz. Bibl. Nauk. PAU i PAN - Rocznik Biblioteki Nuakowej PAU i PAN w Krakowie

Rocz. Hum. - Roczniki Humanistyczne

Rocz. Kom. Nauk Pedag. - Rocznik Komisji Nauk Pedagogicznych

Rocz. Lub. - Rocznik Lubelski

Rocz. Łódz. - Rocznik Łódzki

Rocz. Maz. - Rocznik Mazowiecki

Rocz. Muz. - Rocznik Muzealny

Rocz. Nauk. AWF - Roczniki Naukowe AWF w Poznaniu

Rocz. Nauk Praw. - Roczniki Nauk Prawnych

Rocz. Nauk Społ. - Roczniki Nauk Społecznych

Rocz. Pedag. - Rocznik Pedagogiczny

Rocz. Pol.-Niem. - Rocznik Polsko-Niemiecki

Rocz. SMJ - Rocznik Stowarzyszenia Miłośników Jarosławia

Rocz. Tar. - Rocznik Tamowski

Rocz. Wrock. - Rocznik Wrocławski

Rocz. Wsch. - Rocznik Wschodni

Stud. Teki Hist. - Studenckie Teki Historyczne 
Studia Bibl. AS - Studia Bibliologiczne Akademii Świętokrzyskiej Śl. Kwart. Hist. Sobótka - Śląski Kwartalnik Historyczny Sobótka Śl. Studia Hist.-Teol. - Śląskie Studia Historyczno-Teologiczne Teka Kom. Hist. - Teka Komisji Historycznej Wiad. Num. - Wiadomości Numizmatyczne Zap. Kuj.-Dobrz. - Zapiski Kujawsko-Dobrzyńskie Zesz. Hist. WiN-u - Zeszyty Historyczne WiN-u Zesz. Nauk. UJ - Zeszyty Naukowej Uniwersytetu Jagiellońskiego Zesz. Sand. - Zeszyty Sandomierskie

Zesz. Staszycowskie - Zeszyty Staszicowskie 


\section{OPRACOWANIA OGÓLNE. BIBLIOGRAFIE}

1. AKADEMICKA kultura fizyczna wczoraj i dziś. Praca zbiorowa. Na 95-lecie sportu akademickiego w Polsce (1908-2003). In memoriam prof. Mikołaj Tarasiewicz [1931-2001] et mgr Edward Sądecki [1949-2003]. Pod red. Andrzeja Nowakowskiego i Stanisława Zaborniaka. Rzeszów 2004 Podkarpackie Tow. Nauk. Kultury Fizycznej ss. 145, il., sum. (Studia i Szkice z Historii Kultury Fizycznej. Nr 2).

Z treści: Działalność dydaktyczna Studium Wychowania Fizycznego i Sportu Politechniki Rzeszowskiej w latach 1964-1984 s. 19-29; Rejman Aneta: Wychowanie fizyczne z uwzględnieniem roli AZS w Wyższej Szkole Pedagogicznej w Rzeszowie w latach 1965-2001 s. 31-38; Ponczek Mirosław, Ponczek Marcin: Olimpijczycy - członkowie AZS i absolwenci katowickiej AWF (1976-2002) (zarys problematyki) s. 39-47; Wełpa Konrad: Działalność Klubu Uczelnianego Akademickiego Związku Sportowego Uniwersytetu Jagiellońskiego w latach $1993-2003$ s. 53-60.

2. ALEKSANDER Kamiński [1903-1978] i jego twórczość pedagogiczna. Dyskusja o przeszłości wobec teraźniejszości i przyszłości. Pod red. Ewy Marynowicz-Hetki, Hanny Kubickiej, Mariusza Granosika. Łódź 2004 Wydaw. Uniw. Lódzkiego ss. 461, il. Pod patronatem Kom. Nauk Pedagog. PAN. (Stała Konferencja Pedagogiki Społecznej. [T.] 3).

Z treści: Theiss Wiesław: Aleksander Kamiński - kartki z życiorysu (w świetle korespondencji z Heleną Radlińską oraz Ryszardem Wroczyńskim) s. 12-19; Kamiński Aleksander: List-pamiętnik s. 20-28; Czerniawska Olga: Mój Profesor s. 29-32; Skalska Zofia: Wspólna aktywność. Ludzie znaczący i praca z patronem s. 33-39; Michalski Grzegorz: Teoria stowarzyszeń społecznych Aleksandra Kamińskiego a badania historyczno-edukacyjne s. 133-140; Kukołowicz Teresa: Polskie zwiazki młodzieży do połowy XIX w. w ujęciu Aleksandra Kamińskiego i aktualność koncepcji teoretycznej s. 141-145; Zbierski Andrzej: Skauting, harcerstwo, „Szare Szeregi” w myśli pedagogicznej Aleksandra Kamińskiego „Na dziś, jutro, pojutrze” s. 336-341; Czarnota Wanda: Twórczość pedagogiczna Aleksandra Kamińskiego jako twórcy i redaktora naczelnego „Biuletynu Informacyjnego" Armii Krajowej s. 393-398.

3. BIBLIOGRAFIA historii wychowania, szkolnictwa i myśli pedagogicznej w Polsce za rok 2002 (z uzupetnieniami za lata poprzednie). Oprac. Anna Gruca. Biul. Hist. Wych. 2004 nr 1/2 s. 81-122.

4. GRZELAKOWSKA Elżbieta, Pietras Tomasz: Dwadzieścia lat działalności Muzeum Oświaty Ziemi Łódzkiej. Rocz. Lódzki. T. 51: 2004 s. 262-270.

Od 1983.

5. GUMUŁA Teresa: Czterdzieści pięć lat „Przeglądu Historyczno-Oświatowego”. Prz. Hist.-Ośw. R. 46: 2003 nr 3/4 s. 5-10.

Od 1947 r.

6. KONTEKSTY i metody w badaniach historyczno-pedagogicznych. Pod red. Tadeusz Jałmużna, Iwonna Michalska, Grzegorz Michalski. Kraków 2004 Impuls ss. 259.

Treść: Jałmużna T., Michalska I., Michalski G.: Wstęp s. 9-10; Cz. 1: Interdyscypliname odniesienia badań naukowych historii wychowania: Palka Stanisław: Pedagogika teoretycznie i praktycznie zorientowana a badania historii wychowania i myśli pedagogicznej s. 13-20; Śliwerski Bogusław: Metateoretyczne badania teorii wychowania s. 21-47; Gajdamowicz Halina: Paradygmaty badań historycznych i ich znaczenie w rozwoju humanistyki s. 49-55; Miksza Małgorzata: Utopia i jej rola w tworzeniu teorii pedagogicznych (wprowadzenie do badań) s. 57-65; Cz. 2: Z dyskursów metodologicznych historii wychowania: Hellwig Jan: Dzieje historii wychowania i jej metodologii w Polsce s. 69-86; Jakubiak Krzysztof: Dyskusje o statusie metodologicznym oraz zadaniach dydaktycznych historii wychowania w okresie II Rzeczypospolitej s. 87-93; Drynda Danuta: Poglądy na przedmiot badań historii wychowania w Polsce w latach 1945-1987. Zbieżność czy kontrowersje? s. 95-104; Jamrożek Wiesław: Z założeń metodologicznych historii wychowania Stanisława Michalskiego s. 96-113; Zalewska-Pawlak Mirosława: Badania porównawcze nad historią myśli pedagogicznej. Problemy metodologiczne s. 115-122; Stopińska-Pająk Agnieszka: Metodologiczne aspekty badań nad rozwojem polskiej 
myśli andragogicznej s. 123-133; Poznański Karol: Młodzież szkół średnich epoki oświecenia jako przedmiot badań s. 135-148: Cz. 3: Źródła i metody badań historyezno-pedagogicznych: Mokrzecki Lech: Źródła do dziejów nauczania historii w szkolnictwie epoki wczesnonowożytnej s. 151-159; Żołądź-Strzelczyk Dorota: Instrukcje rodzicielskie jako źródło do badań dziejów wychowania XVI i XVII wieku s. 161-170; Michalski G.: Źródla do badań biograficznych w historii wychowania s. 171-181; Podgórska Eugenia: Autobiografia jako źródło do historii wychowania s. 173-191; Kicowska Alicja: Prasa jako źródło w badaniach historyczno-edukacyjnych (wybrane problemy) s. 193-199; Michalska I.: Możliwości wykorzystania czasopisma dla dzieci jako źródła wiedzy o wychowaniu s. 201-207; Koźmian Danuta: Czasopisma uczniowskie jako cenne źródło do badań dziejów wychowania i szkolnictwa w Drugiej Rzeczypospolitej s. 209-221; Jałmużna T.: Twórczość literacka źródłem do historii wychowania s. 223-229; Sztobryn Sławomir: Historia doktryn pedagogicznych - niepokoje interpretacyjne s. 225-238; Leżańska Wiesława: Wyjaśnianie w badaniach nad ideałami wychowawczymi Drugiej Rzeczypospolitej s. 239-248; Cyrański Bohdan: Cenzura jako przesłanka stosowalności hermeneutycznej metody interpretacji tekstu s. 249-254; Latacz Ewa: Modele naukomoteryczne w badaniach nad recepcja metody Marii Montressori w Polsce jako przykład przechodzenia od badań ilościowych do jakościowych s. 255-259.

7. MÓłKA Janusz: Koncepcja wychowawcza księdza Mieczysława Kuznowicza SJ (1874-1945). Przedm. Tadeusz Aleksander. Kraków 2004 Wyższa Szkoła Filoz.-Pedagog. „Ignatianum"; Wydaw. WAM ss. 314, nlb. 1, tabl. 16, sum.

8. PIOTROWSKA Ewa, Zając Renata: Bibliografia prac Profesora Czesława Majorka za lata 1967-2002. [W:] W służbie szkoły i nauki. Księga poświęcona Profesorowi Czesławowi Majorkowi. Kraków 2003 s. 18-37.

9. SPOŁECZEŃSTWO, opieka, wychowanie. Prace dedykowane Irenie Jundzilł w osiemdziesięciolecie urodzin. Pod red. Jana Żebrowskiego. Gdańsk 2004 Wydaw. Uniw. Gdańskiego ss. 307, nlb. 1 , il.

Z treści: Żebrowski J.: Słowo wstępne s. 7-10; Segit Roman: Z pedagogiką przez życie. Z życia i działalności zawodowej i naukowej profesor Ireny Jundziłł s. 13-27; Wywiad z profesor Ireną Jundziłł. s. 28-32; Żebrowska Danuta: Wychowawczy aspekt współczesnych polskich czasopism dziecięcych s. 75-88; Żebrowski J.: Pedagogiczne aspekty czasopisma „Mały Przegląd” Janusza Korczaka s. 199-204.

10. SZULAKIEWICZ Władysława: Biografistyka i jej miejsce w historiografii edukacyjnej po II wojnie światowej. Biul. Hist.i Wych. 2004 nr 1/2 s. 5-14.

11. SZULAKIEWICZ W.: Historia wychowania 1995-2004. Środowisko - kierunki badań perspektywy rozwoju. Rocz. Pedag, T. 27: 2004 s. 59-76.

12. SZULAKIEWICZ W.: Instytucjonalizacja lwowskiej historii oświaty i kultury. [W:] Wielokulturowe środowisko historyczne Lwowa w XIX i XX w. T. 2. Pod red. Jerzego Maternickiego, Leonida Zaszkilniaka. Rzeszów 2004 s. 329-350.

13. SZULAKIEWICZ W.: „Rozprawy z Dziejów Oświaty” (1958-2003). Studium z historii czasopisma. Toruń 2004 Wydaw. UMK ss. 178, il., sum., Zsfg.

14. SZYMCZAK Kinga: Powiązania rodzinne wśród twórców polskiej teorii i praktyki edukacyjnej, konferencja naukowa, Gniezno 28-30.11.2004 r. Biul. Hist. Wych. 2004 nr 1/2 s. 133-136.

15. SLIWERSKI Bogusław: Wspólnota badań porównawczych w naukach o wychowaniu Polski i Niemiec po II wojnie światowej. Lub. Rocz. Pedag. T. 24: 2004 s. 23-34.

16. WIKOWSKI Lech: Dwoistość w pedagogice Bogdana Suchodolskiego [1903-1992] (z aneksem o Sergiuszu Hessenie). Kraków-Toruń 2001 WIT-GRAF ss. 227. UJ. Inst. Spraw Publicznych. Katedra Teorii Edukacji i Kultury. 
17. WYBRANE problemy oświaty i szkolnictwa Lubelszczyzny. Bibiiografia adnotowana za lata 1995-1998. Oprac. zespół pod red. Grażyny Bownik-Zawadzkiej, Haliny Kołodziejczyk, Grażyny Stomy. Lublin 2002 Pedagog. Bibl. Woj. im. Komisji Edukacji Nar. ss. 86, nlb. 1.

\section{ROZWóJ OŚWIATY, WYCHOWANIA I MYŚLI PEDAGOGICZNEJ}

\section{Opracowania ogólne}

18. ADAMCZYK Mieczysław: Szkolnictwo Spiszu od XVI do początku XX wieku. [W:] Terra Scepusiensis. Stav bádania o dejinách Spiša. Vedec. red. Ryszard Gładkiewicz a Martin Homza. Levoča-Wrocław 2003 s. 681-695.

19. BEDNARSKA-RUSZAJOWA Krystyna: Uczyć, bawić, wychowywać. Książka i jej funkcja społeczna w Polsce w okresie Oświecenia. Kraków 2004 Impuls ss. 253, il., sum.

20. EDUKACJA w społeczeństwie wielokulturowym. Rocz. Lub. T. 30: 2004 cz. 1 s. 13-223, Zsfg.

Z treści: Drozd Roman: Szkolnictwo ukraińskie w Polsce w latach 1944-1989 - próba periodyzacji s. 25-37; Dudra Stefan: Nauczanie religii prawosławnej jako element wielokulturowości Środkowego Nadodrza s. 39-50; Mironowicz Eugeniusz: Szkolnictwo białoruskie w Polsce po II wojnic światowej s. 89-101; Nitschke Bernadetta: Szkolnictwo dla mniejszości niemieckiej w Polsce w latach 1945-1989 s. 103-111; Pecuch Mirosław: Wpływ szkolnictwa na procesy akulturacji, asymilacji i rekulturacji Łemków s. 131-139; Skobelski Robert: „Polski październik” 1956 roku a polityka władz Czechosłowacji wobec polskiego szkolnictwa mniejszościowego na Zaolziu w latach 1957-1959 s. 155-164; Symyk Marek: Nauczanie języka ukraińskiego w Polsce po roku 1989 s. 179-187; Strutyński Władysław: Polska oświata na Ukrainie s. 207-211; Ślusar Oleg: Nauczanie języka polskiego na Uniwersytecie Czerniowieckim im. J. Fedkowycza s. 213-215; Wojecki Mieczysław: Szkolnictwo uchodźców politycznych z Grecji w Polsce po roku 1950 s. 217-223.

21. GAJOWNICZEK Janusz: Dzieje oświaty w Dolicach. Stargardia. T. 3: 2003 s. 345-352.

Lata 1535-1947.

22. GOLĄB Krzysztof: Historia orzegowskiego szkolnictwa w latach 1856-1945. Rudzki Rocz. Muz. [R. 6]: 2003 [druk.:] 2004 s. 115-140.

23. GÓRSKI Jan: Zarys dziejów hołdunowskiego szkolnictwa. Lędziny-Katowice 2004 Infomax ss. 144 , il.

W Lędzinach, XVIII-XXI w.

24. GRABIŃSKA Joanna: Zarys rozwoju oświaty rolniczej w Polsce do 1939 roku. Szkice Podlaskie. Z. 12: 2004 s. 81-96.

25. GRADKOWSKI Henryk: Szkolna recepcja Słowackiego w XIX i pierwszej połowie XX wieku. Częstochowa 2004 Wydaw. Akad. im. Jana Długosza ss. 235, nlb. 3. Akad. im. Jana Długosza w Częstochowie.

26. GULCZYŃSKA Justyna: Społeczno-edukacyjna działalność sióstr Marii, Lucyny i Zofii Sokolnickich. Biul. Hist. Wych. 2004 nr 1/2 s. 41-47.

W szkołach dla dziewcząt w Poznaniu w 1. 1909-1939.

27. KAZANÓW nad Ilżanką. Pod red. Marcina Sołtysiaka. Sycyna 2004 Stow. Oświatowe „Sycyna" ss. 230, nlb. 1, tabl. 16, mapy. (Biblioteka Sycyńska. T. 17).

Z treści: Gajdzińska Krystyna: Publiczne Przedszkole w Kazanowie s. 129-131; Sołtysiak M., Oleksiewicz Jadwiga: Publiczna Szkoła Podstawowa w Kazanowie s. 131-137; Rusin Beata: Publiczne Gimnazjum w Kaza- 
nowie s. 138-141; Pietrzyk Stanisław: Zasadnicza Szkoła Rolnicza w Kazanowie s. 141-145; Pietrzyk S.: Wieczorowe Technikum Rolnicze w Kazanowie s. 146-147; Jasińska Liliana: Publiczna Szkoła Podstawowa w Kowalkowie s. 147-150; Oleksiewicz-Mężyk Joanna: Publiczna Szkoła Podstawowa w Niedarczowie s. 151-152; Modrzejewska-Genca Monika, Posłuszna Zofia: Publiczna Szkoła Podstawowa w Zakrzówku s. 153-155; Sołtysiak M.: Nauczyciele s. 156-171.

28. KORDEK Agnieszka: Dokształcanie lekarzy pracujących na ziemiach polskich w oświacie do roku 1939. Arch. Hist. i Filoz. Med. T. 67: 2004 z. 1 s. 79-83, sum.

Od $1900 \mathrm{r}$.

29. KUSTRA Czesław: Rozwój teorii opieki nad dzieckiem na ziemiach polskich w XIX i w pierwszej połowie XX wieku. Prz. Hist.-Ośw. R. 46: $2003 \mathrm{nr} 3 / 4$ s. 45-60.

30. LEŚNIOWSKA-ŚCIGALSKA Wiesława: Higiena i medycyna szkolna w Polsce wczoraj, dziś, jutro. Mysłowice 2004 Gómośląska Wyższa Szkoła Pedagog. im. Kard. Augusta Hlonda w Mysłowicach ss. 368, il.

31. MAKOWSKI Mariusz: Macierz Ziemi Cieszyńskiej - 120 lat. Kalendarz Cieszyński. [T. 21]: 2005 [druk.:] 2004 s. 25-28.

Dzieje stowarzyszenia w 1. 1885-2004.

32. MALKO Wanda: 100 lat szkolnictwa muzycznego w Częstochowie 1904-2004. Częstochowa 2004 Częstochowskie Zakłady Graf. ss. 333, il.

33. MAŁE miasta. Kultura i oświata. Pod red. Mariusza Zemło. Supraśl 2004 Stow. „Collegium Suprasliense" ss. 439, tabl. 2, mapy.

Z treści: Romaniuk Zbigniew: Studenci z miast podlaskich na Akademii Krakowskiej od XV do XVIII w. s. 265-281; Szot Adam: Ustawa Fryderyka Wilhelma II z 1805 r. o szkolnictwie w Prusach Nowowschodnich s. 283-307; Radecki Sławomir: Szkolnictwo parafialne w Knyszynie w I poł. XIX w. s. 309-316; Czajkowski Mieczysław: Działalność opiekuńczo-wychowawcza księży salezjanów w Różanymstoku i w Supraślu s. 317-330; Wróblewska Urszula: Edukacja religijna Tatarów polskich (zarys problemu) s. 359-367.

34. MĄCZYŃSKI Ryszard: Edukacja z zakresu sztuk plastycznych w warszawskich szkołach pijarów (1740-1833). Analecta. R. 13: 2004 z. 1/2 s. 25-65, sum.

35. NAUCZANIE domowe dzieci polskich od XVIII do XX wieku. Zbiór studiów. Pod red. Krzysztofa Jakubiaka i Adama Winiarza. Bydgoszcz 2004 Wydaw. Akad. Bydgoskiej im. Kazimierza Wielkiego ss. 368 , il., sum.

Z treści: Jakubiak K., Winiarz A.: Wprowadzenie s. 7-10; Jakubiak K.: Stan i potrzeby badań nad nauczaniem domowym dzieci polskich od XVIII do początków XX wieku s. 11-18; Fijałkowski Adam: Nauczanie domowe przedoświeceniowe s. 28-34; Szybiak Irena: O rodzicielskich zaletach i wadach w oświeceniowej polskiej publicystyce edukacyjnej s. 35-45; Waksmund Ryszard: Pokój dziadunia. Wzory edukacji domowej w XIX-wiecznej literaturze dla dzieci i młodzieży s. 49-59; Michalska Iwonna: Przyczynki Teofila Nowosielskiego do edukacji domowej s. 60-69; Jałmużna Tadeusz: Henryk Wernic o nauczaniu domowym s. 70-72; Kabzińska Łucja: Teoretyczne przesłanki nauczania domowego w Królestwie Polskim $w$ drugiej połowie XIX i poczatkach XX wieku s. 73-90; Michalski Grzegorz: Wskazania dla edukacji domowej w wybranym czasopiśmiennictwie polskim drugiej połowy XIX i w pierwszych latach XX wieku s. 91-99; Drynda Danuta: Praca domowa uczniów w poglądach i praktyce szkolnej Drugiej Rzeczypospolitej (1918-1939) s. 100-107; Winiarz A.: Nauczanie domowe dzieci polskich w dobie niewoli narodowej (1795-1918) s. 111-151; Wróbel-Lipowa Krystyna: Nauka domowa możnowładztwa i ziemiaństwa polskiego w XIX wieku s. 152-165; Bartnicka Kalina: Pensja żeńska jako substytut wychowania domowego w początkach XIX wieku w Polsce s. 166-190; Nawrot Monika: Organizacja, dobór przedmiotów i treści oraz metody nauczania domowego w Królestwie Polskim w świetle relacji pamiętnikarskich z XIX i początków XX wieku s. 191-211; Adamczyk Kazimierz: Na obczyźnie i w kraju. Nauczanie domowe Wladysława Zamoyskiego s. 212-220; Ryś Jan, Ślęczak Ryszard: Polskie elementarze do nauki domowej w XIX wieku s. 221-228; Szarkowska Agnieszka: Rola wychowania religijnego 
w nauczaniu domowym dzieci w okresie zaborów s. 229-237; Wojtkiewicz Aneta: Rola „Śpiewnika domowego" Stanisława Moniuszki w nauczaniu domowym s. 238-242; Epsztein Tadeusz: Wpływ zainteresowań intelektualnych rodziców na edukację domową dzieci w polskich domach ziemiańskich na Ukrainie w drugiej połowie XIX wieku s. 243-252; Stopińska-Pajak Agnieszka: Kalendarz w rodzinnym nauczaniu domowym na Gómym Śląsku (od połowy XIX wieku do II wojny światowej) s. 253-266; Sapia-Drewniak Eleonora: Wspieranie edukacji rodzinnej przez Kościół katolicki na Śląsku na przełomie XIX i XX wieku s. 267-274; Grzybowski Romuald: Udział prasy w nauczaniu domowym dzieci polskich na Pomorzu Nadwiślańskim w drugiej połowie XIX i w pierwszych latach XX wieku s. 275-287; Suchmiel Jadwiga: Udzial kobiet w nauczaniu domowym na przełomie XIX i XX stulecia s. 288-294; Stolińska-Pobralska Nella: Nauczanie domowe w katolickich placówkach opiekuńczo-wychowawczych dla dzieci w okresie międzywojennym s. 295-301; Szulakiewicz Whadysława: Istota i swoistość zawodu nauczyciela domowego (Bronisława Ferdynanda Trentowskiego pedeutologia utylitarna) s. 305-314; Kabacińska Katarzyna: Nauczyciel domowy - ideał a rzeczywistość s. 315-323; Leżańska Wiesława: Bony i freblanki w polskim systemie wychowania domowego s. 324-330; Karłowska Grażyna: Specyfika zawodu nauczyciela domowego $w$ świetle czasopism pedagogicznych i rodzinnych na przykładzje „Przeglądu Pedagogicznego” (1882-1905) i „Kroniki Rodzinnej” (1867-1915) s. 331-345.

36. PAWLAK Marian: Studia młodzieży wileńskiej w protestanckich uczelniach środkowej i zachodniej Europy. [W:] W kręgu badań profesora Wacława Odyńca. Materiały z sesji naukowej poświęconej pamięci profesora Wacława Odyńca. Red. nauk Józef Włodarski. Gdańsk 2002 s. $235-251$.

37. POLICZNA. By czas nie zaćmił i niepamięć. Pod red. Eugenii Januszewicz. Sycyna-Radom 2004 Stow. Oświatowe „Sycyna”; Inst. Technologii Eksploatacji ss. 205, tabl. 24, mapa. (Biblioteka Sycyńska. T. 15).

Z treści: Adamiec Maria: Publiczne Gimnazjum im. Stefana Żeromskiego w Policznie s. 101-106; Ziemka Barbara: Zespół Placówek Oświatowo-Wychowawczych w Policznie s. 107-114; Mierzejewska-Figura Justyna: Zespół Szkolno-Przedszkolny w Czarnolesie s. 114-118; Piątkowska Marianna: Publiczna Szkoła Podstawowa w Wilczowoli - dawniej i dziś s. 118-122; Maciejczyk Dorota: Publiczna Szkola Podstawowa w Chechłach s. $122-125$.

38. PORONIN dawniej i dziś. Praca zbiorowa. Pod red. Anieli Bafii i Teresy Nocoń; przy współudz. Franciszka Lojasa-Kośli i Bronisława Chowańca-Lejczyka. Poronin 2004 Zw. Podhalan. Oddz.; Urząd Gminy ss. 797, il., mapy.

Z treści: Bobak Alicja, Borgosz Barbara, Tokarczyk Dorota: Z dziejów przedszkola w Poroninie s. 351-355; Chowaniec Zofia: Rys historyczny szkoly s. 356-378; Bafia A.: Tajne nauczanie i samorządowe gimnazjum w Poroninie s. 379-386.

39. REDZIK Adam: Organizacja i funkcjonowanie szkolnictwa elementarnego w drugiej połowie XIX wieku i w II Rzeczypospolitej na przykładzie Rejonu Tuchowicko-Stanińskiego w Ziemi Łukowskiej. Kościół, społeczeństwo, kultura. Prace ofiarowane profesorowi Wiesławowi Mũllerowi z okazji pięćdziesięciolecia pracy naukowej i dydaktycznej. Pod red. Janusza A. Droba. Lublin 2004 s. $441-456$.

40. ROMANOWSKA Ewa, Dąbrowska Joanna: Jubileusz prof. dr hab. Józefa Miąso. Seminarium „Atlas historyczny szkół na ziemiach polskich: Problemy sieci szkolnej Okręgu Naukowego Wileńskiego", Pułtusk 3-4.06.2004 r. Biul. Hist. Wych. 2004 nr 1/2 s. 128-129.

41. RONDOMIŃSKA Zenona: Wychowanie przez muzykę w szkołach na polskiej Warmii w XX wieku. Olsztyn 2003 OBN im. W. Kętrzyńskiego ss. 150, tabl. 3, Zsfg. ( Rozprawy i Materiały Ośrodka Badań Naukowych im. Wojciecha Kętrzyńskiego w Olsztynie. Nr 209).

42. SEJKO Natalia: Polskie Škilnictvo na Volyni-Žitomirščini u XIX-pieršij polovini XX st. Žitomir 2003 Žitomirs'kij dieržavnyj piedagogičnij universitet im. Ivana Franka ss. 158. 
43. SKŁADANOWSKI Henryk: Stosunki polsko-sowieckie w programach nauczania i podręcznikach historii w szkole powszechnej (podstawowej) w Polsce w latach 1932-1956. Toruń 2004 Wydaw. Adam Marszałek ss. 345, rez., sum.

44. SURDACKI Marian: Edukacja i opieka społeczna w Urzędowie XV-XVIII w. Lublin 2004 Tow. Nauk. KUL ss. 364, nlb. 4, tabl. 4, sum. (Prace z Historii Szkolnictwa w Polsce. T. 11) (Źródła i Monografie. [T.] 272).

45. SZYMCZAK Alicja: Sprawozdanie z sesji popularnonaukowej „650 lat szkolnictwa w Rawie Mazowieckiej”. Rocz. Lódz. T. 51: 2004 s. 279-281.

Rawa Mazowiecka, 22 X 2004 r.

46. SZYSZKA Bogdan: Związki kulturalno-oświatowe Lwowa i Zamościa. Prz. Hist.-Ośw. R. 47: $2004 \mathrm{nr} 1 / 2$ s. 75-84.

XVI-XX w.

47. ŚLĄSKA republika uczonych. Schlesische Gelehrtenrepublik. Slezká védecka obec. Vol. 1. Red. Marek Hałub i Anna Mańko-Matysiak. Wroclaw 2004 Oficyna Wydawnicza ATUT Wrocławskie Wydaw. Oświatowe ss. 766, nlb. 1, il., shrnutí, streszcz., Zsfg.

Z treści: Zonta Claudia A.: Schlesische Studenten an italienischen Universitäten der frühen Neuzeit s. 217-237; Lenz Rudolf: Christoph Hackner und die Jesuitenuniversität zu Breslau. Materialien zu Planung und Bau der „Universitas Leopoldina” s. 238-263; Garber Klaus: Schlesiens Bildungslandschaft zwischen Barock und Aufklärung im Kontext des Späthumanismus s. 288-301; Dąbrowska Anna: Podręcznik do nauki języka polskiego autorstwa nauczyciela ze Wschowy Andreasa Polsfusa s. 381-397; Joachimsthaler Jürgen: „Bildung” für die Polen. Anschaulichkeit, Ganzwortmethode und „Realismus” als Instrumente der wilhelminischen Germanisierungspolitik in Oberschlesien s. 513-528; Herzig Arno: Die schlesische Friedrich-Wilhelms-Universität in Breslau. Von ihrer Gründung bis zur Gleichschaltung unter dem Nationalsozialismus (1933/34) s. 529-554.

48. ŚWIEŻY Artur, Żurek Waldemar Witold: Salezjańska działalność wychowawczo-dydaktyczna w Przemyślu na Zasaniu w latach 1907-1945. Arch. Bibl. i Muzea Kośc. T. 82: 2004 s. 305-378, Zsfg.

49. TYLIŃSKA Ewelina: „Atlas historyczny szkół na ziemiach polskich. Problemy sieci szkolnej okręgu naukowego wileńskiego" - seminarium 4 czerwca 2004 r. w Pułtusku. Kwart. Hist. Nauki i Techn. R. 49: $2004 \mathrm{nr} 3 / 4$ s. 276-278.

50. W SŁUŻBIE szkoły i nauki. Księga poświęcona Profesorowi Czesławowi Majorkowi. Pod red. Zygmunta Ruty i Ryszarda Ślęczki. Kraków 2003 Wydaw. Nauk. Akad. Pedagog. ss. 329, nlb. 7, tabl. 2.

Z treści: Ruta Z.: In memoriam s. 5-17; Urban Wayne J.: The United States of America, Poland and International Educational Understanding, 1945-1948 s. 46-52; Jalmużna Tadeusz: Czasopisma źródłem do badań historyczno-pedagogicznych s. 53-57; Ryś Jan: Zasoby internetowe we współczesnych badaniach historyczno-oświatowych s. 58-64; Maternicki Jerzy: Instytucjonalizacja i profesjonalizacja polskiej dydaktyki historii w XX w. s. 72-79; Nowarski Czesław: Dydaktyka historii w rozumieniu Czesława Majorka s. 80-85; Szmyd Kazimierz: W wielokulturowej rzeczywistości oświatowo-pedagogicznej Lwowa. Problematyka badań i poglądy Czesława Majorka s. 86-97; Drynda Danuta: Wychowanie ku wartościom w twórczości pedagogów Drugiej Rzeczypospolitej - ofertą dla wspólczesności s. 98-104; Brynkus Józef: Świadomość historyczna w perspektywie postmodernistycznej s. 105-108; Miąso Józef: Początki wyższych szkół technicznych w zaborze rosyjskim s. 111-122; Poznański Karol: Trudne narodziny Instytutu Szlacheckiego w Warszawie s. 123-139; Możdżeń Stefan: Egzamin maturalny w galicyjskich szkołach średnich 1849-1914 s. 151-156; Massalski Adam: Nauczyciele śpiewu w męskich szkołach średnich rządowych Królestwa Polskiego w latach 1833-1862 s. 157-165; Meissner Andrzej: Szkoła i nauczyciel na łamach „Gazety Nauczycielskiej” 1899-1904 s. 166-173; Jamrożek Wiesław: Uniwersytet Ludowy im. Adama Mickiewicza w ruchu oświatowym Galicji 
s. 174-184; Potoczny Jerzy: Powszechne Wykłady Uniwersyteckie we Lwowie (1899-1918) s. 185-199; Kucha Ryszard: Badania naukowe Zakładu Historii Wychowania i Pedagogiki Porównawczej UMCS w Lublinie w latach 1957-2003 s. 218-228; Krukowski Jan: O Wszechnicy, Wszechni i Wszechniku. Polemika o nowe nazwy i o prawie drukowania ,wet za wet szyderstw za szyderstwa" s. 231-240; Dybiec Julian: Problem jezykowy w Uniwersytecie Jagiellońskim w XVIII-XX w. s. 241-252; Banach Andrzej Kazimierz: Młodzież chłopska z powiatu tarnowskiego na Uniwersytecie Jagiellońskim w latach 1860/61-1917/18 s. 253-259; Gawlik Stanislaw: Uczeń w poglądach pedagogicznych Grzegorza Piramowicza s. 263-271; Szybiak Irena: Jędrzej Śniadecki o wychowaniu dzieci chorych i upośledzonych s. 272-277; Szulakiewicz Władysława: Lwowski okres w życiu i działalności naukowej Antoniego Knota s. 294-303; Kliś Andrzej: Rola rodziny w wychowaniu dziecka w galicyjskiej refleksji pedagogicznej s. 307-314; Jakubiak Krzysztof: Wzorzec rodziny i idee wychowania rodzinnego dziecka wypracowane i propagowane na łamach „Kroniki Rodzinnej” i „Opiekuna Domowego" w drugiej połowie XIX wieku s. 315-324; Ślęczka R.: Ogólnopolski konkurs prac magisterskich z historii edukacji im. Profesora Czesława Majorka s. 325-329.

Rec.: Kucha Ryszard, Lub. Rocz. Pedag. T. 24: 2004 s. 351-354.

51. WYSZCZELSKI Lech: Oświata, propaganda, kultura w Wojsku Polskim w latach 1918-1945. Warszawa 2004 Neriton ss. 317, nlb. 1, sum.

52. Z NAJNOWSZEJ historii kultury fizyczej w Polsce. T. 6: Prace naukowe Letniej Szkoły Historyków Kultury Fizycznej. Pod red. Leonarda Nowaka. Gorzów Wielkopolski 2004 ZWKFP AWF ss. 604, il. Zamiejscowy Wydz. Kultury Fizycznej Poznańskiej AWF W Gorzowie Wlkp., Pol. Tow. Nauk. Kultury Fizycznej. Oddz. w Gorzowie Wlkp.

$Z$ treści: Nowak L.: Znaczenie instytucji państwowych $w$ rozwoju bazy materialnej wychowania fizycznego i sportu szkolnego w Polsce w latach 1918-1939 s. 125-131; Małolepszy Eligiusz: Kultura fizyczna w działalności Wołyńskiego Związku Młodzieży Wiejskiej w latach 1922-1939 s. 155-164; Huzarski Maciej: Wychowanie fizyczne w szkołach ogólnokształcących Rzeszowa w latach 1949-1956 s. 395-405; Malinowska Irmina: Działalność Akademickiego Związu Sportowego przy Uniwersytecie Wileńskim w latach 1921-1939 s. 525-536.

\section{Okres do 1795 roku}

53. AUSZ Mariusz: Realizacja programu nauczania Komisji Edukacji Narodowej w szkole chełmskiej księży pijarów. Res Historica. Z. 18: 2004 s. 13-30.

Lata $1773-1793$.

54. BIALUSZ Waldemar: Kulturotwórcza rola Kolegium Jezuickiego w Sandomierzu (XVII-XVIII w.). Zesz. Sand. R. 9: $2002 \mathrm{nr} 16$ s. 9-15.

55. BICZ na akademików krakowskich. Antologia. Oprac. Roman Dąbrowski. Kraków 2003 Universitas ss. 141.

Rec.: Kostkiewiczowa Teresa, Wiek Oświecenia. T. 20: 2004 s. 185-186.

56. BOGDAN Danuta: Pobyt Johanna Gottfrieda Herdera na uniwersytecie w Królewcu w latach 1762-1764. Kom. Mazur.-Warm. [R. 47]: 2003 nr 4 [druk.:] 2004 s. 451-465, Zsfg.

57. BORKOWSKA Urszula: Edukacja i mecenat artystyczny Władysława Jagiellończyka, króla Czech i Wegier. [W:] Polacy w Czechach, Czesi w Polsce X-XVIII wiek. Pod red. Henryka Gmiterka, Wojciecha Iwańczaka. Lublin 2004 s. 193-207.

58. BORODA Krzysztof: Książka w życiu studentów Uniwersytetu Krakowskiego w XV i początkach XVI stulecia. [W:] Cała historia to dzieje ludzi. 
Studia $\mathrm{z}$ historii społecznej ofiarowane profesorowi Andrzejowi Wyczańskiemu w 80-tą rocznicę urodzin i 55-lecie pracy naukowej. Pod red. Cezarego Kukli; przy współudz. Piotra Guzowskiego. Białystok 2004 s. $39-54$.

59. BUDZYŃSKI Józef: Paideia humanistyczna, czyli wychowanie do kultury. Studium z dziejów klasycznej edukacji w gimnazjach XVI-XVIII wieku (na przykładzie Śląska). Częstochowa 2003 Wydaw. WSP ss. 602, nlb. 2, il. Wyższa Szkoła Pedagog. w Częstochowie.

60. CHACHAJ Marian: Edukacja lubelskiego lekarza Piotra Kliszewskiego (zm. w 1625 r.). Res Historica. Z. 17: 2004 s. 133-144.

61. CHACHAJ M.: Prawnicze promocje doktorskie profesorów zamojskich na Uniwersytecie Bolońskim. Res Historica. Z. 17: 2004 s. 121-131.

XVII w.

62. CZYŻYK Marta: Studia uniwersyteckie kanoników gnieźnieńskich w I połowie XV wieku w świetle metryki kapitulnej. [W:] Księga, nauka, wiara w średniowiecznej Europie. Pod red. Tomasza Ratajczaka. Poznań 2004 s. 103-113.

63. ĆWIKŁA Leszek: Działalność edukacyjna prawosławnych bractw cerkiewnych w Rzeczypospolitej w XVI-XVII wieku. Rocz. Nauk. Spot. T. 32: 2004 z. 2 s. 95-111, sum.

64. DELIMA Małgorzata: Dziecko w Polsce średniowiecznej. Poznań 2004 Wydaw. Poznańskie ss. 259.

Rec.: Wojciechowska Beata, Prz. Hist. T. 95: 2004 z. 3 s. 407-409.

65. DZIĘGIELEWSKI Roman: Henryk Milich - tajemniczy lektor języka polskiego w Gdańsku z 1655 roku. Libri Gedanenses. T. 21: 2003 [dr.:] 2004 s. 55-77, sum., Zsfg.

66. GRZEBIEŃ Ludwik: Nauczyciele i wychowawcy cieszyńskiego gimnazjum jezuickiego 1678-1773. Analiza katalogów zakonnych. [W:] Studia historycznoprawne. Prace dedykowane profesorowi Janowi Seredyce w siedemdziesiąta piątą rocznicę urodzin i czterdziestopięciolecie pracy naukowej. Pod red. Janusza Dorobisza, Włodzimierza Kaczorowskiego. Opole 2004 s. $89-96$.

67. KACZMAREK Hieronim: Starożytny Egipt w podręcznikach szkolnych czasów Komisji Edukacji Narodowej. Kwart. Hist. Nauki i Techn. R. 49: 2004 nr 3/4 s. 39-70, sum.

68. KAMLER Anna: Uwagi o wykształceniu małopolskiej elity władzy w szesnastym wieku. [W:] Cała historia to dzieje ludzi. Studia $z$ historii społecznej ofiarowane profesorowi Andrzejowi Wyczańskiemu w 80-tą rocznicę urodzin i 55-lecie pracy naukowej. Pod red. Cezarego Kukli; przy współudz. Piotra Guzowskiego. Białystok 2004 s. 143-148.

69. KUCZ Anna: Rola teatru szkolnego na Sląsku w okresie poreformacyjnym. Śl. Studia Hist.-Teol. T. 37: 2004 z. 2 s. 191-199, somm.

XVI-XVIII w.

70. KUPISZ Anna: Działalność pisarska nauczycieli kolegium jezuickiego w Lublinie w XVI-XVII wieku. [W:] W służbie Bogu i społeczeństwu. Zakony na ziemiach polskich w XVI-XIX wieku. Pod red. Dariusza Kupisza. Radom 2004 s. 7-18.

71. MULARCZYK Jerzy: Nauczyciela węgierskiego podróż po Polsce. Ślqsk. R. 8: $2002 \mathrm{nr} 10$ s. $50-52$.

Peregrynacje Węgra Mortona Csombora w 1. 1616-1618. 
72. PELCZAR Roman, Lorens Beata: Cerkiewne szkoły brackie w eparchii przemyskiej w XVI-XVIII wieku. Rocz. Kom. Nauk Pedag. T. 57: 2004 s. 5-21, sum.

73. PRZYBYSZEWSKA-JARMIŃSKA Barbara: Muzyka w szkołach ogólnokształcących i zawodowe kształcenie muzyków w Rzeczypospolitej XVII i XVIII w. Kronika Zamkowa. Nr 46: 2003 [druk.:] 2004 s. 29-40, sum.

74. PUCHOWSKI Kazimierz: „Collegium Nobilium” Stanisława Konarskiego a elitarne instytucje wychowawcze zakonów nauczających w Europie. Wiek Oświecenia. T. 20: 2004 s. 11-70, rés.

75. PUCHOWSKI K.: Edukacja „losem urodzenia wyznaczonych" w warszawskim kolegium teatynów (1737-1785). [W:] Między barokiem a oświeceniem. Sarmacki konterfekt. Praca zbiorowa pod red. Stanisława Achremczyka. Olsztyn 2002 s. 79-94.

76. RATAJCZAK Krzysztof: Miracula z „Żywota świętej Jadwigi”, księżnej Śląska jako źródło do dziejów wychowania. Biul. Hist. Wych. $2004 \mathrm{nr}$ 1/2 s. 14-22.

77. RÓŻAŃSKI Mieczysław: Sieć szkół parafialnych w archidiakonacie uniejowskim w XVIII wieku do czasów Komisji Edukacji Narodowej. [W:] Kościół i historia. Drogi i wzajemne powiązania. Księga pamiątkowa ku czci księdza profesora Anzelma Weissa. Pod red. Stanisław Tylus, Jan Walkusz. Lublin 2001 s. 247-262.

78. SERWAŃSKI Maciej: Na marginesie badań nad edukacją szlachcianek w Polsce XVI-XVII wieku. [W:] Cała historia to dzieje ludzi. Studia z historii społecznej ofiarowane profesorowi Andrzejowi Wyczańskiemu w 80-tą rocznicę urodzin i 55-lecie pracy naukowej. Pod red. Cezarego Kukli; przy współudz. Piotra Guzowskiego. Białystok 2004 s. 149-155.

79. STOPKA Krzysztof: Uniwersytet w rzeczywistości politycznej późnośredniowiecznej Europy. [W:] Kolory i struktury średniowiecza. Pod red. Wojciecha Falkowskiego. Warszawa 2004 s. $43-56$.

80. SZYMAŃSKI Kamila: Popisy uczniów wschowskiej szkoły katolickiej z lat 1787 i 1789. Prz. Hist.-Ośw. R. 46: 2003 nr 3/4 s. 175-185.

81. SZYMAŃSKI Kamila: Teatr luterańskiej szkoły miejskiej w Lesznie w XVII i XVIII wieku. Odrodzenie i Reformacja w Polsce. T. 48: 2004 s. 171-182, sum.

82. TREGER Bronisław: Edukacja i satyra. Przyczynek do analizy koncepcji wychowawczych i działalności oświatowej Franciszka Salezego Jezierskiego. Napis. Ser. 8: 2002 s. 51-72.

Uzup.: Jezierski Franciszek Salezy: Życie domowe Piasta podczas panowania i rozmowa jego w Gnieźnie $z$ żoną o wychowaniu młodzieży $z$ okazyi syna swego Semowita. Opr. B. Treger. Tamże s. 73-77.

83. WESOŁOWSKA Sylwia: Szkolnictwo wiejskie na Pomorzu w XVIII wieku. [W:] Dzieje wsi pomorskiej. III międzynarodowa konferencja naukowa, Włościbórz, gmina Dygowo, powiat kołobrzeski, 14-16 maja 2004. Materiały. Pod red. Radosława Gazińskiego i Andrzeja Chludzińskiego. Dygowo-Szczecin 2004 s. 27-36.

84. WŁODAREK Andrzej: Przestrzeń architektoniczna średniowiecznych uniwersytetów na przykładzie burs i kolegiów Uniwersytetu Krakowskiego. [W:] Kolory i struktury średniowiecza. Pod red. Wojciecha Fałkowskiego. Warszawa 2004 s. 86-103.

85. WOLOSZYŃSKI Ryszard W.: Między tradycją a reformą. Nauczyciele w Polsce XVIII wieku. Piotrków Trybunalski 2000 Wydaw. Filii Kieleckiej WSP ss. 280, nlb. 1. Wyższa Szkoła Pedagog. im. Jana Kochanowskiego w Kielcach. Filia w Piotrkowie Trybunalskim. Inst. Historii. 
86. ŻOŁĄDŹ-STRZELCZYK Dorota: „Edukacja dam świeckich” w klasztorze w Ołobucku w XVIII w. [W:] Cysterki w dziejach i kulturze ziem polskich, dawnej Rzeczypospolitej i Europy Środkowej. Materiały z siódmej Międzynarodowej Konferencji Cystersologów odbytej z okazji 800. rocznicy fundacji opactwa cysterek w Trzebnicy. Trzebnica, 18-21 września 2002 r. Red. Andrzej M. Wyrwa, Antoni Kiełbasa, Józef Swastek. Poznań 2004 s. 747-756.

\section{Okres 1795-1918}

87. ALBINIAK Monika Elżbieta: Działalność opiekuńczo-wychowawcza Zgromadzenia Sióstr Opatrzności Bożej w latach 1857-1905. Lublin 2004 TNKUL ss. 352, nlb. 2, tabl. 2. Tow. Nauk. KUL. (Prace z Historii Szkolnictwa w Polsce. T. 8) (Źródła i Monografie. [Nr] 253).

88. AUSZ Mariusz: Edukacja w świetle „Urządzenia tymczasowego szkół pijarskich” z $1808 \mathrm{r}$. Res Historica. Z. 18: 2004 s. 31-41.

89. AUSZ Mariusz: Szkoły pijarskie w Radomiu, Lukowie, Chelmie i Opolu Lubelskim w latach 1809-1815. [W:] W shużbie Bogu i społeczeństwu. Zakony na ziemiach polskich w XVI-XIX wieku. Pod red. Dariusza Kupisza. Radom 2004 s. 113-123.

90. BARON Roman: Współpraca Macierzy Szkolnej dla Księstwa Cieszyńskiego z galicyjskim Towarzystwem Szkoły Ludowej. Pam. Cieszyński. T. 19: 2004 s. 47-70.

91. CHẸTNIK Adam: Tajne nauczanie w regionie łomżyńskim pod zaborem rosyjskim. Ziemia Lomżyńska. [R.] 8: 2004 s. 153-160.

92. CZARNIECKI Stanisław: Jan Kasprowicz - kontynuator myśli wychowawczej Stanisława Staszica. Zesz. Staszicowskie. Z. 4: 2004 s. 225-240.

93. CZERWIEŃ Henryk, Kapuśniak Magdalena: Elementarze szkolne wydawane w jasnogórskiej drukarni. Studia Claromontana. [T.] 22: 2004 s. 391-404, sum.

W aneksie wykaz elementarzy wydanych w l. 1802-1863.

94. DOBROWOLSKI Stanisław: Towarzystwo Szkoły Ludowej w Wiedniu w latach 1904-1914. Pr. Hist.-Archiw. T. 14: 2004 s. 83-102.

95. FRANKOWICZ Józef: Wychowanie fizyczne w szkołach i kluby sportowe w Przemyślu w dobie autonomii Galicji. Przemyśl 2004 Regionalny Ośr. Kultury, Edukacji i Nauki; Józef Frankiewicz ss. 208, il., mapy.

96. FRANKOWSKA Ewa: Początki kariery nauczycielskiej ks. J[ana] Schindlera na Uniwersytecie Jagiellońskim w latach 1832-1836. Folia Hist. Crac. Vol. 10: 2004 s. 81-90, sum.

97. FRĄCKIEWICZ Joanna: Patriotyczne przesłanie do młodzieży pedagoga Jana Nepomucena Leszczyńskiego [1806-1886]. Prz. Hist.-Ośw. R. 46: 2003 nr 3/4 s. 131-142.

98. GONDEK Elżbieta: Kultura i oświata. [W:] Zagłębie Dąbrowskie w czasach zaborów i walk o niepodleglość. (Do 1918 roku). Praca zbiorowa. Pod red. Jana Walczaka. Sosnowiec 2004 s. 147-179.

99. GÓRCZYŃSKI Wit: Podręcznikowe zarysy dziejów Polski Henryka Schmitta. [W:] Wielokulturowe środowisko historyczne Lwowa w XIX i XX w. T. 2. Pod red. Jerzego Maternickiego, Leonida Zaszkilniaka. Rzeszów 2004 s. 70-81. 
100. GRADKOWSKI Henryk: Z dziejów szkolnej recepcji Słowackiego w wieku XIX (rekonesans). [W:] Od oświecenia ku romantyzmowi i dalej... Autorzy, ich dzieła, czytelnicy. Pod red. Marka Piechoty i Janusza Ryby. Katowice 2004 s. 199-220.

101. GRUCA Anna: Profesorowie Uniwersytetu Jagiellońskiego jako nakładcy swoich prac w dobie autonomii galicyjskiej. Rocz. Bibl. Nauk. PAU i PAN w Krakowie. R. 49: 2004 s. 231-244, sum.

102. HARATYK Anna: Udział społeczeństwa krakowskiego w niesieniu pomocy dzieciom w drugiej połowie XIX i na początku XX wieku. Prz. Hist.-Ośw. R. 47: 2004 nr 1/2 s. 85-101.

103. JAGŁA-TOKARSKA Kinga: Życie teatralne w nowotarskim Gimnazjum w latach 1905-1914. Almanach Nowotarski. Nr 8: 2004 s. 52-58.

104. KAREOWICZ Grażyna: Edukacja domowa dziewcząt w rodzinie polskiej XIX i na początku XX wieku w świetle pamiętników. Biul. Hist. Wych. 2004 nr 1/2 s. 23-38.

105. KEMPA Andrzej: Oni budowali inteligencką Łódź. Łódzkie kariery wychowanków warszawskiej Szkoły Głównej (1862-1869). Kronika M. Lodzi. 2004 nr 1 s. 112-119.

106. KITOWSKA Małgorzata: Tradycje ruchu turystyczno-krajoznawczego w polskim szkolnictwie pod zaborami (do 1914 roku). [W:] Pokolenia spełnionego obowiązku. Studia z dziejów Polski i Polaków w kraju i na obczyźnie w XX wieku, dedykowane Profesorowi Józefowi Garlińskiemu. Pod red. Janusza Farysia, Romana Nira i Marka Szczerbińskiego. Gorzów Wlkp. 2004 s. $399-406$.

107. KOREDCZUK Józef: Przyczynek do sprawy habilitacji Ignacego Koschembahr-Łyskowskiego we Wrocławiu. Acta Uniw. Wr. No 2616: Prawo. [T.] 288: Studia historycznoprawne: 2004 s. 191-207, Zsfg.

Autor odrzuca twierdzenia o habilitacji we Wrocławiu w 1894 lub 1904 r.; umiejscawiając ją we Fryburgu pod koniec XIX w.

108. KORZENIOWSKA Wiesława: Edukacja i wychowanie różnych warstw społecznych na ziemiach polskich - od drugiej połowy wieku XIX do roku 1918. Kraków 2004 Impuls ss. 244, sum.

109. KOZŁOWSKI Jerzy: Z życia studentów polskich w Würzburgu w XIX wieku. Prz. Pol. R. 30: 2004 z. 4 s. 103-110, sum. 192.

110. KRUSZEWSKI Tomasz: Początki prowincjonalnej opieki nad dziećmi ghuchoniemymi i ociemniałymi na Śląsku w I połowie XIX wieku. Acta Uniw. Wr. No 2616: Prawo. [T.] 288: Studia historycznoprawne: 2004 s. 145-166, Zsfg.

111. LENORT Feliks: Przypomnienie otwarcia nowego seminarium duchownego w Poznaniu w roku 1896. Ecclesia. T. 1: 2003 s. 231-260.

112. ŁUKASIEWICZ Dariusz: Między Kościołem i Państwem. Szkolnictwo w Prusach Południowych (1793-1806). Studia Historica Slavo-Germanica. T. 25: 2003 [druk.:] 2004 s. 45-58, abstr., Zsfg.

113. ŁUKASIEWICZ D.: Szkolnictwo w Prusach Południowych (1793-1806) w okresie reform oświeceniowych. Poznań-Warszawa 2004 Wydaw. PTPN ss. 360, tabl. 1, mapa, sum. Poznańskie Tow. Przyj. Nauk. Wydz. Nauk Hist.; Inst. Historii PAN. (Prace Komisji Historycznej. T. 63). 
114. MALANOWSKA Aniela: Żeńskie pensje prywatne w Łomży. Ziemia Lomżyńska. [R.] 8: 2004 s. 161-174.

W XIX-XX w.

115. MALARA Aleksandra: Popularyzacja oświaty zdrowotnej i problematyki higienicznej na podstawie czasopisma dla ludu „Zorza” z lat 1866-1905. Wrocław 2004 Arboretum ss. 144.

116. MASSALSKI Adam: Zwierzchnicy rządowych, męskich szkół średnich w Królestwie Polskim w latach 1833-1862. Kielce 2004 Wydaw. Akad. Świętokrzyskiej im. Jana Kochanowskiego ss. 239 , nlb. 1 , tabl. 15 .

117. MATUS Irena: Powiatowy Oddział Diecezjalnej Rady Szkolnej w Bielsku w latach 1890-1915 - działalność i skład personalny. Bialorus. Zesz. Hist. $\mathrm{Nr} 21: 2004$ s. 70-82, rez.

118. MEISSNER Andrzej: Nauczycielski nurt badań nad historią wychowania we Lwowie w XIX i na początku wieku XX (do I wojny światowej). [W:] Wielokulturowe środowisko historyczne Lwowa w XIX i XX w. T. 2. Pod red. Jerzego Maternickiego, Leonida Zaszkilniaka. Rzeszów 2004 s. $160-171$.

119. OLSZEWSKA Maria Jolanta: Studenci z Królestwa Polskiego przed powstaniem styczniowym. (Glosa do „Lalki” Bolesława Prusa). Warszawa 2004 Wydz. Polonistyki Uniw. Warszawskiego ss. 230, il. (Z Publikacji Zakładu Pozytywizmu i Młodej Polski).

120. OMILANOWSKA Malgorzata: Polscy architekci w petersburskiej Akademii Sztuk Pięknych w latach 1814-1918. Biul. Hist. Szt. R. 66: 2004 nr 3/4 s. 351-373, sum.

121. PACHOCKA Anna: Efemeryczny świat wspomnień - zabawy i zabawki dzieci możnych rodziców w I połowie XIX wieku. Teka Kom. Hist. Vol. 1: 2004 s. 161-175, sum.

122. PAWLIK Marta: Opieka medyczna nad niemowlęciem na ziemiach polskich przełomu XVIII i XIX wieku w świetle poradników medycznych. Stud. Teki Hist. Z. 2: 2004 s. 40-50.

123. POZNAŃSKI Karol: Obraz gimnazjów i szkół powiatowych w guberni lubelskiej, augustowskiej i płockiej w oczach wizytatora szkól Józefa Korzeniowskiego w 1853 r. Prz. Hist.-Ośw. R. 47: $2004 \mathrm{nr} 3 / 4$ s. 107-130.

124. POZNAŃSKI K.: Oświata i szkolnictwo w Królestwie Polskim 1831-1869. Lata zmagań i nadziei. [T.] 3: Polityka oświatowa caratu w latach 1834-1861. Warszawa 2004 Akad. Pedagogiki Specjalnej im. Marii Grzegorzewskiej ss. 303, il.

125. POZNAŃSKI K.: Wychowanie fizyczne w programach szkół prywatnych i rządowych w Warszawie w XIX wieku. [W:] Wkład nauk humanistycznych do wiedzy o kulturze fizycznej. T. 1: Historia kultury fizycznej. (Studia i szkice). Red. nauk. Tadeusz Rychta, Jerzy Chełmecki. Warszawa 2003 s. $58-64$.

126. ROGALA Agata: Czynniki rozwoju szkolnictwa średniego Łodzi przemysłowej (1885-1914). [W:] Studia z historii społeczno-gospodarczej XIX i XX wieku. T. 2. Pod red. Wiesława Pusia. Łódź 2003 s. 35-50.

127. SCHRÖDER Christoph: Planung und Gürndung der Königlichen Akademie zu Posen 1897-1903. Studia Historica Slavo-Germanica. T. 25: 2003 [druk.:] 2004 s. 73-99, abstr.

128. SKOWRON Andrzej: Dzieje szkolnictwa ziemi dąbrowskiej w okresie porozbiorowym. Szkolnictwo galicyjskie w latach 1772-1918. Rocz. Tar. [T.] 9: 2003/2004 [dr.:] 2004 s. 87-109. 
129. SŁAWIŃSKI Piotr: Absolwentki i grono pedagogiczne Szkoły Maryjskiej z 1907 roku [w Sandomierzu]. Zesz. Sand. R. 9: 2002 nr 16 s. 55-57.

130. SOCHA Irena: „Für die Jugend nicht geeignete - dla młodzieży niewłaściwe...” O cenzurowaniu książek szkolnych w drugiej połowie XIX wieku na Śląsku austriackim. [W:] W kręgu książki, biblioteki i informacji naukowej. Księga jubileuszowa dedykowana profesorowi Zbigniewowi Żmigrodzkiemu. Pod red. Krystyny Heskiej-Kwaśniewicz; przy współpr. Diany Pietruch-Reizes. Katowice 2004 s. 250-261.

131. SROKA Stanisław T[adeusz], Turczyńska Ewa: Dzieje oświaty i postępu rolniczego w Małopolsce do uzyskania niepodległości w roku 1918. Kwart. Hist. Nauki i Techn. R. 48: 2003 nr 3/4 s. 139-148.

132. STINIA Maria: Państwowe szkolnictwo gimnazjalne w Krakowie w okresie autonomii galicyjskiej. Kraków 2004 Historia Iagellonica ss. 268, tabl. 4.

133. SZEWCZUK Dariusz: Ochronki w guberni lubelskiej w latach 1853-1914. Res Historica. Z. 18: 2004 s. $43-55$.

134. SZYNKIEWICZ Ewa: Podręcznik „Geografia dla klasy pierwszej szkół średnich” i „Atlas geograficzny" Eugeniusza Romera na tle nauczania geografii w Galicji. [W:] Eugeniusz Romer geograf i kartograf trzech epok. Materiały sesji naukowej, Warszawa, 16 kwietnia 2004 rok. Red. nauk. t. Jerzy Ostrowski, Jacek Pasławski, Lucyna Szaniawska. Warszawa 2004 s. 77-87.

135. SLIZ Małgorzata: „Fundacja na stypendia dla biednych uczniów Wydziału Lekarskiego Akademii Jagiellońskiej bł. Leona Szancera" [1802-1879] i jej twórca. Arch. Hist. i Filoz. Med. T. $67: 2004$ z. $2 / 4$ s. $139-149$, sum.

136. ŚMIECHOWSKA Elżbieta: System wychowania w polskiej szkole drugiej polowy XIX wieku; ujęcie krytyczno-projektujące w twórczości beletrystycznej Adolfa Dygasińskiego. Prz. Hist.-Ośw. R. 46: 2003 nr 3/4 s. 159-166.

137. TYLIŃSKA Ewelina: Drogi do kariery akademickiej kobiet na ziemiach polskich na przełomie XIX i XX wieku. Kwart. Hist. Nauki i Techn. R. 48: $2003 \mathrm{nr}$ 3/4 s. 155-161.

138. WÓJCIK Zbigniew J[erzy]: O humanistach polskich, wychowankach uniwersytetu i innych uczelni w Dorpacie (Juriewie). Acta Uniw. Wr. No 2606: Wrocławskie Studia Wschodnie. [T.] 7: 2003 s. 85-108, rez., sum.

Lata 1802-1918.

139. WRÓBLEWSKI Maciej: Wybrane problemy genologiczne w XIX-wiecznych podręcznikach szkolnych do nauki teorii literatury. Acta UNC. Nauki Hum.-Społ. Z. 366: Filologia polska. [Nr] 60: Literatura. 2004 s. 199-219, sum.

140. ZABORNIAK Stanisław: Elementy lekkoatletyki w programach szkolnego wychowania fizycznego w szkolach polskich na przełomie XIX i XX wieku. [W:] Wkład nauk humanistycznych do wiedzy o kulturze fizycznej. T. 1: Historia kultury fizycznej. (Studia i szkice). Red. nauk. Tadeusz Rychta, Jerzy Chełmecki. Warszawa 2003 s. 65-72.

141. ZAWADZKA Danuta: Retoryka i historyka - wykład inauguracyjny Joachima Lelewela na Uniwersytecie Wileńskim (styczeń 1822). [W:] Teatr wymowy. Formy i przemiany retoryki użytkowej. Pod red. Jolanty Sztachelskiej oraz Janusza Maciejewskiego i Elżbiety Dąbrowicz. Białystok 2004 s. 265-280. 
142. ZWIĄZEK Jan: Obrońcy języka polskiego w progimnazjum częstochowskim w XIX wieku. Almanach Częstochowy. [T. 17]: 2004 s. 73-85.

143. ZWIAZZEK J.: Przeciwko rusyfikacji polskich uczniów w progimnazjum częstochowskim (1880-1894). Częst. Studia Teol. [T.] 31: 2003 [druk.:] 2004 s. 293-313.

\section{Okres $1918-1939$}

144. BOGUSZEWSKA Anna: Pracownie i gabinety rysunkowe w polskich seminariach nauczycielskich oraz pedagogiach w okresie międzywojennym. Prz. Hist.-Ośw. R. 46: 2003 nr 3/4 s. 187-197.

145. CHWASTYK-KOWALCZYK Jolanta: Oświata i wychowanie na łamach „Bluszczu” w latach 1918-1939. Studia. Bibl. AŚ. T. 7: 2003 s. 31-61, sum.

146. CIĄŻELA Andrzej: Pedagogika Bogdana Suchodolskiego w dwudziestoleciu międzywojennym - próba periodyzacji. Kwart. Pedag. R. 49: 2004 nr 3 s. 145-161.

147. CIMAŁA Bogdan: Emanuel Konstanty Imiela [1887-1953] - organizator szkolnictwa na Śląsku. Rocz. Świętoch. T. 6: 2004 s. 23-40, Zsfg.

148. CIMAŁA B.: Szkolnictwo mniejszościowe na Górnym Śląsku w okresie międzywojennym. [W:] Doświadczenia polityki mniejszościowej okresu międzywojennego na górnośląskim obszarze plebiscytowym. Pod red. nauk. Michała Lisa. Opole 2004 s. 123-138.

149. DOROSZEWSKI Jerzy: Dążenia oświatowe ludności ukraińskiej na Lubelszczyźnie w latach 1918-1939. Prz. Hist.-Ośw. R. 47: 2004 nr 1/2 s. 5-23.

150. DOROSZEWSKI Jerzy: Szkolnictwo miasta Lublina w latach 1918-1939. Szkolnictwo powszechne, zakłady kształcenia nauczycieli, szkolnictwo artystyczne. Lublin 2004 Lubelskie Tow. Nauk. ss. 174, il., sum., Zsfg.

151. FUNKACJA prywatnych szkół średnich w II Rzeczypospolitej 1918-1939. Pod red. Elwiry Jolanty Kryńskiej. Białystok 2004 Trans Humana ss. 356, tabl. 8.

Z treści: Kryńska E. J.: Wstęp s. 9-12; Polskie tradycje szkolnictwa prywatnego: Wróbel-Lipowa Krystyna: Kształcenie dzieci Stanisława Zamoyskiego XII ordynata na Zamościu s. 15-20; Stinia Maria: Nauczyciele prywatnych klasycznych gimnazjów żeńskich w Krakowie w okresie autonomii galicyjskiej s. 21-29; Ausz Mariusz: Rola szkolnictwa pijarskiego w okresie zaborów s. 30-38; Haratyk Anna: Zakład Wychowawczy św. Jadwigi dla ubogich dziewcząt rozpoczynających pracę (Galicja XIX/XX w.) s. 39-47; Szarkowska Agnieszka: Szkolnictwo w gubernii grodzieńskiej i w obwodzie białostockim w zaborze rosyjskim (1831-1905) s. 48-57; Polityka oświatowa władz szkolnych wobec szkolnictwa prywatnego w II Rzeczypospolitej: Wyszczelski Lech: Polityka oświatowo-wychowawcza władz II Rzeczypospolitej w latach 1918-1926 w odniesieniu do młodzieży szkół średnich s. 61-69; Osiński Zbigniew: Szkolnictwo prywatne w koncepcjch Janusza Jędrzejewicza s. 70-79; Sadowska Joanna: Wpływ ustawodawstwa jędrzejowiczowskiego na szkolnictwo prywatne w II Rzeczypospolitej s. 80-89; Gumuła Teresa: Prywatne szkoły żeńskie w systemie oświatowym II Rzeczypospolitej - stan badań, postulaty badawcze s. 90-100; Samsel Agata: Koedukacja w II Rzeczypospolitej - teoria i praktyka s. 101-111; Mauersberg Stanisław: Uwagi dotyczące prywatnych szkół średnich ogólnokształcących w Polsce Niepodległej (1918-1939) s. 112-115; Szkolnictwo prywatne w różnych regionach II Rzeczypospolitej: Majewski Stanisław: Rozmieszczenie prywatnych szkół średnich ogólnokształcących w II Rzeczypospolitej 1918-1939 s. 119-127; Gulczyńska Justyna: Funkcja społeczna niepublicznego szkolnictwa średniego ogólnokształcącego na przykładzie szkół poznańskich w okresie międzywojennym s. 128-136; Piwowarczyk Mirosław: Rola szkół prywatnych w aktywizowaniu małych społeczności lokalnych w Wielkopolsce w okresie II Rzeczypospolitej (na przykładzie Gostynia) s. 137-150; Glimos-Nadgórska Anna: Specyfika prywatnego szkolnictwa średniego, ogólnokształcącego funkcjonującego w międzywojennym województwie śląskim 
(1922-1939) s. 151-161; Kempa Grażyna: Wychowawczo-społeczne i zawodowe wyznaczniki prywatnego żeńskiego szkolnictwa rzemieślniczo-przemysłowego na Gómym Śląsku w latach 1922-1939 s. 162-168; Gąsiorowski Andrzej: Z dziejów walki o prywatną szkołę średnią na Warmii, Mazurach i Powiślu (1920-1939) s. 169-181; Kozaczyńska Beata: Niepaństwowe szkoły średnie w Siedlcach w latach 1918-1939 s. 182-187; Kryńska E. J.: Prywatne szkoły średnie ogólnokształcące w województwie białostockim (1918-1939) s. 188-196; Walasek Stefania: Prywatne szkolnictwo na ziemiach Nowogródzkiego i Wileńskiego KOS [Kuratorium Okręgu Szkolnego] w II Rzeczypospolitej s. 197-210; Markiewiczowa Hanna: Szkolnictwo średnie Polskiej Macierzy Szkolnej na Kresach Wschodnich w II Rzeczypospolitej s. 211-221; Sanojca Karol: Prywatne szkoły średnie Lwowa w okresie międzywojennym i ich dzialalność wychowawcza s. 222-231; Szkoły prywatne II Rzeczypospolitej we wspomnianiach i pamiętnikach: Walczak Marian: Moja prywatna szkoła zawodowa w latach 1936-1939 s. 235-239; Kubis Barbara: Szkolnictwo prywatne II Rzeczypospolitej w świetle literatury wspomnieniowej s. 240-254; Kula Ewa, Pękowska Marzena: Rękopiśmienne pamiętniki i wspomnienia uczniów jako źródło wiedzy o polskim średnim szkolnictwie niepublicznym w II Rzeczypospolitej s. 255-262; Jaroszuk Teresa: Prywatna szkoła średnia II Rzeczypospolitej w ujęciu Stanisława Lukasiewicza s. 263-270; Pozalekcyjna działalność wychowawcza w II Rzeczypospolitej: Walewander Edward: Rola Kościoła w realizacji funkcji społecznej prywatnych szkół s. 273-274; Puschowska Małgorzata: Teatr Konwiktu Chyrowskiego (1886-1939) i jego rola w edukacji teatralnej elit s. 275-283; Wegierski Zbigniew: Funkcja społeczna i pedagogiczna internatów szkolnych w II Rzeczypospolitej s. 284-297; Jakubiak Krzysztof: Wiejskie osiedla szkolne prywatne gimnazjów w II Rzeczypospolitej s. 298-305; Grądzki Władysław: Internaty edukacyjną szansą młodzieży wiejskiej w latach 1933-1939 i 1949-1951 s. 306-311; Kryńska E. J.: Słowo końcowe s. 351-353.

152. GULCZYŃSKA Justyna: Sprawozdanie z Konferencji Naukowej w Augustowie (26-27. 05.2003). Biul. Hist. Wych. 2004 nr 1/2 s. 123-124.

Nt.: Funkcja społeczna prywatnych szkół średnich Drugiej Rzeczypospolitej.

153. GUZEK Mariusz: Bydgoskie kina oświatowe w II Rzeczypospolitej. I. T. $25: 2003$ [dr.:] 2004 s. $144-153$.

154. JAROSZUK Teresa: Szkolna osnowa pamiętnikarskiej powieści Stanisława Łukasiewicza „Nauczyciele" (1936). Prz. Hist.-Ośw. R. 46: 2003 nr 3/4 s. 143-157.

155. JOMIEC Grzegorz: Szkolnictwo żydowskie w powiecie tomaszowskim w latach 1918-1939. Prz. Hist.-Ośw. R. 46: 2003 nr 3/4 s. 117-125.

156. JUSKO Edmund: Działalność wychowawczo-opiekuńcza szkół powszechnych w powiecie tamowskim w latach 1918-1939. Rocz. Hum. T. 52: 2004 z. 2 s. 145-179, sum.

157. JUŚKO E.: Struktura organizacyjna szkół powszechnych w powiecie tarnowskim $\hat{w}$ latach 1918-1939. Rocz. Nauk. Spol. T. 32: 2004 z. 2 s. 113-143, sum.

158. KAROLEWICZ Grażyna: Więzy nauczycieli akademickich Katolickiego Uniwersytetu Lubelskiego z Wielkopolską w okresie międzywojennym. [W:] Kościół i historia. Drogi i wzajemne powiązania. Ksiega pamiątkowa ku czci księdza profesora Anzelma Weissa. Red. Stanisław Tylus, Jan Walkusz. Lublin 2001 s. 185-193.

159. KITOWSKA Małgorzata: Opieka władz państwowych nad turystyką i krajoznawstwem w szkolnictwie polskim w latach 1919-1939. [W:] Studia z dziejów Polski i Europy w XIX i XX wieku. Ksiega dedykowana Profesorowi Piotrowi Stefanowi Wandyczowi. Pod red. Janusza Farysia, Romana Nira i Marka Szczerbińskiego. Gorzów Wlkp. 2004 s. 549-560.

160. KOSTRZEWA-MAJOCH Agnieszka: Między Poznaniem a Wilnem. Archiwum fonograficzne Uniwersytetu Stefana Batorego w świetle korespondencji Romana Padlewskiego z Marią Znamierowską-Prtfferowa. Muzyka. R. 49: 2004 nr 4 s. 133-153, sum.

W aneksie fragmenty korespondencji z 1. 1933-1937. 
161. KOWALSKI GRZEGORZ M.: O miejsce historii prawa w programie studiów uniwersyteckich. Polemika między Oswaldem Balzerem a Juliuszem Makarewiczem (1919-1923). Czasop. Prawno-Hist. T. 56: 2004 z. 2 s. 345-362.

162. KOZACZYŃSKA Beata: Sprawozdanie z konferencji naukowej na temat: „Funkcja społeczna prywatnych szkół średnich w Drugiej Rzeczypospolitej Polskiej (1918-1939)”, Augustów, 26-27 maja 2003 roku. Prz. Hist.-Ośw. R. 47: 2004 nr 1/2 s. 145-148.

163. KRAŚKO Nina: Szkoła w teoriach wychowawczych i publicystyce Kościoła katolickiego w II Rzeczypospolitej. Kultura i Spoleczeństwo. T. 47: 2003 nr 1 s. 179-190.

164. KRZEMIŃSKI Kamil: Szkoły ponadpodstawowe Naddźwinia 1919-1939. Toruń 2004 Mado ss. 520, il., mapy.

165. KULAK Teresa: Problem nauczania historii regionalnej i lokalnej w szkołach średnich w świetle obrad Powszechnych Zjazdów Historyków Polskich w latach 1925-1935. [W:] Wokół historii i polityki. Studia z dziejów XIX i XX wieku dedykowane profesorowi Wojciechowi Wrzesińskiemu w siedemdziesiątą rocznicę urodzin. Pod red. Stanisława Ciesielskiego, Teresy Kulak, Krzysztofa Ruchniewicza i Jakuba Tyszkiewicza. Toruń 2004 s. 463-473.

166. KULAK T.: Profesor Ewa Maleczyńska [1900-1972] wśród prekursorów edukacji regionalnej i lokalnej w polskim szkolnictwie średnim w latach 1931-1939. Sl. Kwart. Hist. Sobótka. R. 59: 2004 nr 3 s. $423-433$.

167. MAJEWSKI Stanisław: Organizacja szkolnictwa w II Rzeczypospolitej w dobie realizacji reformy lat 1932-1939. [W:] W kręgu historii, gospodarki i kultury. Studia dedykowane profesorowi Jerzemu Piwkowi w siedemdziesiątą rocznicę urodzin. Pod red. Sebastian Piątkowski. Ostrowiec Swiętokrzyski 2004 s. 155-161.

168. MALISZEWSKI Krzysztof: Teoria wychowania moralnego w pedagogice kultury II Rzeczypospolitej. Katowice 2004 Wydaw. UŚ ss. 189, nlb. 3, sum., Zsfg. ( Prace Naukowe Uniwersytetu Śląskiego w Katowicach. Nr 2270).

169. MAŠČUK Anatolij: Działalność kulturalno-oświatowa organizacji bundowskich na terytorium Zachodniej Białorusi w okresie międzywojennym. [W:] Polsko-białoruskie związki językowe, literackie, historyczne i kulturowe. T. 6: Materiały XI Międzynarodowej Konferencji Naukowej „Droga ku wzajemności” Białystok 18-20 VII 2003. Pod red. Michała Kondratiuka, Bazylego Siegienia. Białystok 2004 s. 569-580.

170. MAZUR Piotr: Szkolnictwo na Lubelszczyźnie w świetle prasy lokalnej 1918-1939. Lublin 2004 Liber ss. nlb. 4, 237, nlb. 5, tabl. 10, mapy. (Biblioteka Pedagogiczna Instytutu Pedagogiki Wydziału Nauk Społecznych Katolickiego Uniwersytetu Lubelskiego. Ser. A: Studia. T. 7).

Rec.: Walewander Edward, Rocz. Nauk. Spol. T. 32: 2004 z. 2 s. 165-167; Wróbel-Lipowa Krystyna, Lub. Rocz. Pedag. T. 24: 2004 s. 363-367.

171. MIĄSO Józef: Szkoły techniczne w Drugiej Rzeczypospolitej. Prz. Hist.-Ośw. R. 47: 2004 nr $3 / 4$ s. 5-19.

172. MISZEWSKI Dariusz: Polityka władz czechosłowackich wobec szkolnictwa polskiego na Śląsku Zaolziańskim w latach 1920-1938. Prz. Hist.-Ośw. R. 46: $2003 \mathrm{nr}$ 3/4 s. 25-43.

173. NAWROT Dariusz: Kadra dydaktyczna uczelni polskiej Marynarki Wojennej w latach 1922-1939. Pr. Morski. R. 67: 2002 z. 9 s. 17-30. 
174. NITECKI Piotr: Formacja intelektualna ks. Stefana Wyszyńskiego podczas studiów na Katolickim Uniwersytecie Lubelskim w latach 1925-1929. [W:] Filozofia pochylona nad człowiekiem. Studia dedykowane księdzu profesorowi Stanisławowi Kowalczykowi. Pod red. Edward Balawajder, Arkadiusz Jabłoński, Jan Szymczyk. Lublin 2004 s. 709-722.

175. NOWAK Leonard: Model szkolnego wychowania fizycznego w II Rzeczypospolitej na tle głównych systemów wychowania fizycznego w Europie. [W:] Przełomy w historii. XVI Powszechny Zjazd Historyków Polskich, Wrocław 15-18 września 1999 roku. Pamiętnik. T. 3 cz. 3. Rada nauk. Krzysztof Ruchniewicz, Jakub Tyszkiewicz, Wojciech Wrzesiński. Toruń 2004 s. 441-445.

176. OLCZAK-KARDAS Monika: Wydawnictwa „Naszej Księgarni” na łamach „Glosu Nauczycielskiego" w latach 1921-1939. Studia. Bibl. AŚ. T. 8: 2004 s. 65-77, sum.

177. PAWŁOWICZOWA Maria: „Księga Pamiątkowa I-go Państwowego Gimnazjum w Stanisławowie" z 1929 roku jako druk zabytkowy oraz dokument. [W:] W kręgu książki, biblioteki i informacji naukowej. Księga jubileuszowa dedykowana profesorowi Zbigniewowi Żmigrodzkiemu. Pod red. Krystyny Heskiej-Kwaśniewicz; przy współpr. Diany Pietruch-Reizes. Katowice 2004 s. 262-274.

178. PELCZARSKI Kazimierz: Ojciec Marian Pirożyński jako propagator wychowania katolickiego w okresie II Rzeczypospolitej. Rocz. Nauk. Spol. T. 31: 2003 z. 2 s. 71-100, sum.

179. PERZANOWSKA Agnieszka: Wzór osobowy katechety-wychowawcy w ujęciu Sługi Bożego ks. Wincentego Granata. Studia Sandomierskie. T. 11: 2004 z. 2 s. 93-114, res.

Katecheza szkolna w 1. 1928-1933.

180. PIĘTKA-LUBOWICKA Anna: Zaopatrywanie szkół w pomoce szkolne w Okręgu Szkolnym Brzeskim. Studia Łomżyńskie. T. 15: 2004 s. 147-159.

W l. 1934-1939.

181. PILCH Andrzej: Studenci Krakowa w Drugiej Rzeczypospolitej. Ich ideowe, polityczne i społeczne zaangażowanie. Kraków 2004 Księg. Akademicka ss. 423, nlb. 5.

182. PISULIŃSKI Jan: Rozmowy na temat powołania uniwersytetu ukraińskiego w 1924 roku. Biul. Ukr. [Nr] 9: 2003 [druk.:] 2004 s. 58-66.

183. PIWOŃ Aleksander: Spór o budynek szkolny w Lesznie w 1937 r. Przyj. Ludu. [R. 18]: 2003 z. 1 s. $25-28$.

184. PYTER Magdalena: Miejsce dyscyplin historycznoprawnych w wykształceniu jurysdycznym w okresie międzywojennym. Rocz. Nauk. Praw. T. 14: 2004 z. 1 s. 105-128, sum.

185. RATAJCZAK Zbigniew: Jak nauczyciele powiatu kościańskiego przyjęli wolność w roku 1918. Pam. TMZK. T. 11: 2001/2004 [dr.:] 2004 s. 107-111,

186. SADOWSKA Joanna: Wychowanie państwowe i jego odbicie w programach szkolnych doby sanacji. Res Historica. Z. 16: 2004 s. 83-93, sum.

187. SAMSEL Agata: Koedukacja w szkołach średnich w Polsce $\mathrm{i}$ na świecie w latach 1918-1939 - świadomy wybór czy zło konieczne. Prz. Hist.-Ośw. R. 47: 2004 nr 3/4 s. 79-87.

188. SANOJCA Karol: Lwowskie władze oświatowe w okresie Drugiej Rzeczypospolitej. [W:] Wokół historii i polityki. Studia z dziejów XIX i XX wieku dedykowane profesorowi Wojciechowi Wrzesińskiemu w siedemdziesiątą rocznicę urodzin. Pod red. Stanisława Ciesielskiego, Teresy Kulak, Krzysztofa Ruchniewicza i Jakuba Tyszkiewicza. Toruń 2004 s. 761-766. 
189. STAŃCZYK Elżbieta: Analfabetyzm w Polsce w okresie dwudziestolecia międzywojennego. Acta Uniw. Wr. No 2664: Prz. Prawa i Admin. T. 63: 2004 s. 197-212.

190. ŠVAJKO Valjancina: Gimnazjum rosyjskie - centrum działalności kulturalno-oświatowej ludności rosyjskiej miasta Brześcia w latach 1921-1939. [W:] Polsko-białoruskie związki językowe, literackie, historyczne i kulturowe. T. 6: Materiały XI Międzynarodowej Konferencji Naukowej „Droga ku wzajemności” Białystok 18-20 VII 2003. Pod red. Michała Kondratiuka, Bazylego Siegienia. Białystok 2004 s. 517-530.

191. SZMYD Kazimierz: Z dziejów Narodowego (Tajnego) Uniwersytetu Ukraińskiego we Lwowie (1919-1926). [W:] Polska i jej wschodni sąsiedzi. T. 5. Pod red. Andrzeja Andrusiewicza. Rzeszów 2004 s. 134-153.

192. SZMYD K.: Z tradycji polskiej pedagogiki wielokulturowej. Kwart. Pedag. R. 48: 2003 nr 4 [druk.:] 2004 s. 25-40, sum.

Środowisko naukowe Uniwersytetu Lwowskiego.

193. SZULAKIEWICZ Wladysława: Zainteresowania badawcze lwowskich historyków oświaty i wychowania lat międzywojennych. [W:] Wielokulturowe środowisko historyczne Lwowa w XIX i XX w. T. 2. Pod red. Jerzego Maternickiego, Leonida Zaszkilniaka. Rzeszów 2004 s. 222-232.

194. SZYMAŃSKI Mirosław S.: „Ruch nowej szkoły” w Drugiej Rzeczypospolitej (1918-1939). Kwart. Pedag. R. 49: 2004 nr 3 s. 7-63, sum.

195. SZYMAŃSKI M. S.: „Ruch przyjaciół dzieci” w Drugiej Rzeczypospolitej (1918-1939). Kwart. Pedag. R. 46: 2001 nr 1 s. 3-30, sum.

196. SZYMAŃSKI M. S.: „Ruch samorządów uczniowskich” w Drugiej Rzeczypospolitej (1918-1939). Kwart. Pedag. R. 48: 2003 nr 3 s. 5-49, sum.

197. WALBURG Mirosława: Problem organizacji szkół powszechnych w Kutnie i w powiecie w latach 1918-1939. Kutn. Zesz. Reg. T. 8: 2004 s. 99-116.

198. WOJTAS Jacek: Szkoły i kursy organizowane na terenie Małopolski Środkowej przez Towarzystwo Szkoły Handlowej i Gimnazjum Kupieckie w Jarosławiu w latach 1936-1939. Rocz. SMJ. T. 15: 2002/2004 [druk.:] 2004 s. 231-236.

199. WYSZCZELSKI Lech: Oświata i propaganda w Wojsku Polskim w latach 1935-1939. Prz. Hist.-Ośw. R. 47: 2004 nr 1/2 s. 25-40.

\section{Okres 1939-1945}

200. BABSZCZYN Piotr: Sprawozdanie $\mathrm{z}$ tajnego nauczania $\mathrm{w}$ Klimontowie $\mathrm{w}$ latach 1940-1944. Do dr. podał, wstępem i przypisami opatrzył Eugeniusz Niebelski. Zesz. Sand. R. 8: $2001 \mathrm{nr} 14$ s. $51-57$.

201. BANDURA Ludwik: Wpływ wojny na psychikę dzieci i młodzieży. (Fragmenty z rozprawy doktorskiej z 1950 roku). Wstęp i oprac. Zbigniew Kwieciński. Toruń 2004 Wydaw. UMK ss. 118 , nlb. 1 , il. 
202. CHMIELEWSKI Witold: Niektóre aspekty koncepcji oświatowych rządu polskiego w czasie drugiej wojny światowej. Prz. Hist.-Ośw. R. 47: 2004 nr 1/2 s. 41-58.

203. CHROBACZYŃSKI Jacek, Kruczek Władysław: Nauczyciele małopolscy. Portret zbiorowy 1939-1945. Kraków 2004 Wydaw. Nauk. AP ss. 352, nlb. 1, tabl. 16, mapy. Akad. Pedagog. im. Komisji Edukacji Nar. w Krakowie. (Prace Monograficzne. Nr 389).

204. GRZELAK Czesław: Wojenna edukacja kadr Wojska Polskiego na froncie wschodnim 1943-1945. Warszawa 2004 Neriton ss. 303, tabl. 32.

205. JAKUBIEC Danuta: Boglarczycy. Krak. Rocz. Archiw. T. 10: 2004 s. 257-262.

Polskie szkoły na Węgrzech w Zamárdi i Balatonboglár oraz stowarzyszenie byłych uczniów; W aneksie: Jelonek-Litewka Krystyna: Informacja o przekazaniu akt Stowarzyszenia „Boglarczycy” do Archiwum Państwowego w Krakowie s. 261.

206. KORNEĆ Grażyna: Oświata powojenna w programach podlaskich ugrupowań konspiracyjnych 1939-1945. Szkice Podlaskie. Z. 12: 2004 s. 31-69.

207. PERKOWSKA Urszula: Relacje o służbie kobiet w Armii Krajowej i Batalionach Chłopskich w świetle akt studenckich Uniwersytetu Jagiellońskiego 1945-1950. [W:] Wojenna służba Polek w II wojnie światowej. Materiały z sesji populamonaukowej w Toruniu w dniu 16 listopada 2002 roku. Pod red. Waldemara Rezmera. Toruń 2003 s. 271-280.

208. ROMANIUK Marek, Śmigiel Kazimierz, Alabrudzińska Elżbieta: Germanizacja oświaty i życia religijnego. [W:] Historia Bydgoszczy. T. 2 cz. 2: 1939-1945. Pod red. nauk. Mariana Biskupa. Bydgoszcz 2004 s. 289-368.

209. ROMANOWICZ Jerzy: Kształcenie oficerów Polskiej Marynarki Wojennej w brytyjskich uczelniach w latach 1939-1945. Prz. Morski. R. 67: 2002 z. 9 s. 31-38.

210. SAKOWSKA Ruta: Konspiracyjne seminarium Hechaluc-Dror w Warszawie (16 grudnia 1941 - 26 stycznia 1942). Notatki Icchaka Cukiermana. Kwart. Hist. Żydów. [R. 3]: 2003 nr 2 s. $209-226$, sum.

211. W SZKOŁACH których nie było - wypiski z kamiennego zeszytu. Wspomnienia uczniów tajnego nauczania. Kol. red. Krzysztof Baszczyński [i in.]. Łódź 2004 ZNP ss. 167, il. Zw. Nauczycielstwa Pol. Zarząd Okręgu Łódzkiego.

Antologia wspomnień.

212. WINCENCIAK Witold: Szkolnictwo polskie na kresach wschodnich w latach 1939-1941. Łomża-Olsztyn 2004 Łomżyńskie Tow. Nauk. im. Wagów; Uniw. Warmińsko-Mazurski ss. nlb. 2, 201, il.

Rec.: Grędzik Agnieszka, Rocz. Wsch. Nr 10: 2004 s. 387-390; Markiewiczowa Hanna, Prz. Hist.-Ośw. R. 47: $2004 \mathrm{nr} 3 / 4$ s. 263-266.

213. ZIÓLKOWSKA Bogdan: Walka o polską oświatę i kulturę na Kujawach wschodnich i w ziemi dobrzyńskiej w latach 1939-1945. Cz. 1: Włocławek. Zap. Kuj.-Dobrz. T. 19: 2004 s. 17-29.

\section{Okres 1945-1989}

214. BARAN Adam F.: Przemówienie gen. Nikodema Sulika do harcerek i harcerzy w kraju na falach RWE. Zesz. Hist. WiN-u. R. 13: $2004 \mathrm{nr} 21$ s. 313-324.

Zawiera też tekst przemówienia z przełomu 1953 i 1954 r. 
215. BIARDA Marek: Szkolnictwo podstawowe i średnie w Siedlcach w latach 1975-1989. Szkice Podlaskie. Z. 12: 2004 s. 11-30.

216. FUDALI Robert: Nauczyciele Dolnego Śląska w okresie tworzenia podstaw „nowego ładu" społecznego 1970-1975. Prz. Hist.-Ośw. R. 47: 2004 nr 1/2 s. 103-119.

217. FUDALI R.: Oświata Dolnego Śląska w okresie ,małej stabilizacji” 1956/57-1969/70 uwarunkowania społeczno-polityczne przemian lat 50. i 60. Prz. Hist.-Ośw. R. 46: 2003 nr 3/4 s. $61-83$.

218. GIESZCZYŃSKI Witold: Protesty studenckie w Olsztynie w 1981 roku. Pamięć i Sprawiedliwość. $2003[\mathrm{nr}] 2$ s. 213-226.

219. GLOWACKI Albin: Problem repatriacji wychowanków polskich domów dziecka z ZSRR (1945-1946). My, Sybiracy. Nr 15: 2004 s. 33-52.

220. GRUDNIK Krzysztof: Wychowanie ideologiczne w szkole polskiej w latach 1945-1953. Prz. Hist.-Ośw. R. 47: 2004 nr 3/4 s. 59-67.

221. HISTORIA szkolnictwa wyższego w Bydgoszczy. Praca zbiorowa. Pod red. Zygmunta Mackiewicza. Bydgoszcz 2004 Bydgoskie Tow. Nauk. ss. 127, il., sum.

Z treści: Tomasik Wojciech: Historia Akademii Bydgoskiej. Bardzo krótki kurs. [Od 1969 r.] s. 9-14; Domaniewski Jan: Powstawanie i rozwój Akademii Medycznej im. Ludwika Rydygjera w Bydgoszczy. [Od 1951 r.] s. 15-23; Nowak Anna: Historia Akademii Muzycznej w Bydgoszczy. [Od 1974 r.] s. 25-34; Topoliński Tomasz: 53 lata istnienia ATR [Akademii Techniczno-Rolniczej im. Jana i Jędrzeja Śniadeckich. Od 1951 r.] s. 35-46; Czakowska Helena: Historia powstania i rozwoju Kujawsko-Pomorskiej Szkoły Wyższej w Bydgoszczy. [Od 2000 r.] s. 47-56; Maciołek Ryszard: Przeszłość i perspektywy rozwoju Wyższej Pomorskiej Szkoły Turystyki i Hotelarstwa w Bydgoszczy. [Od 1999 r.] s. 57-71; Kowalkowska Barbara, Czukiewska Marta: Historia powstania i rozwoju Wyższej Szkoły Ochrony Środowiska w Bydgoszczy. [Od 1998 r.] s. 73-85; Meller Janusz: Historia i współczesność Wyższej Szkoły Zarządzania i Finansów w Bydgoszczy. [Od 1999 r.] s. 87-96; Pietrzykowska Marlena: Konrad Pałubicki [1919-1992] - założyciel Bydgoskiego Towarzystwa Naukowego. [Powstało w 1959 r.] s. 97-105.

222. JAWORSKI Wojciech: Szkolnictwo i nauka. [W:] Rok 1945 w województwie śląsko-dąbrowskim. Pod red. Andrzeja Topola. Katowice 2004 s. 209-220.

223. JELEMITY Witold: Punkty katechetyczne w diecezji lomżyńskiej po 1945 r. Prawo Kanoniczne. R. 47: 2004 [nr] 3/4 s. 147-191, sum.

224. JÓŹWIAK Iwona: Formy opicki państwowej nad dziećmi i młodzieżą w województwie olsztyńskim w latach 1950-1960. Prz. Hist.-Ośw. R. 47: 2004 nr 3/4 s. 147-168.

225. KOLAKOWSKI Andrzej: Stan i potrzeby badań nad rozwojem oświaty, wychowania i kultury fizycznej w okresie PRL - sprawozdanie z sesji naukowej w AWFiS w Gdańsku [8-9 IX 2003 r.]. Pr. Hist.-Ośw. R. 47: 2004 nr 3/4 s. 267-270.

226. KOMARNICKI Henryk: Zjawiska dwuwładzy w życiu uczelni wyższych Szczecina w latach 1980-1981. [W:] Wokół dwuwładzy politycznej w latach 1980-1981. Kraj i region. Materiały z sesji naukowej z 6 grudnia 2002 r. Praca zbiorowa. Pod red. Henryka Komamickiego i Kazimierza Kozłowskiego. Szczecin 2004 s. 115-121.

227. KONOPKA Hanna: Działania represyjne wladz oświatowych w Polsce wobec katechetów w okresie stalinizmu. [W:] Represje wobec duchowieństwa kościołów chrześcijańskich w okresie 
stalinowskim w krajach byłego bloku wschodniego. Pod red. Jerzego Myszora i Adama Dziuroka. Katowice 2004 s. 167-181.

228. KONOPKA H.: Szkolne nauczanie religii w Polsce Ludowej w świetle prawa (1944-1961). [W:] Wielokulturowość polskiego pogranicza. Ludzie, idee, prawo. Materiały ze Zjazdu Katedr Historycznoprawnych, Augustów 15-18 września 2002 roku. Pod red. Adama Lityńskiego i Piotra Fiedorczyka. Białystok 2003 s. 861-872.

229. KUŹMA Ewa: Likwidacja analfabetyzmu w powiecie tomaszowskim $w$ latach 1945-1953. Lub. Rocz. Pedag. T. 24: 2004 s. 303-314.

230. LESIAKOWSKI Krzysztof: Werbunek młodzieży do brygad Powszechnej Organizacji „Służba Polsce” (1948-1955). Dzieje Najnowsze. R. 36: 2004 [nr] 2 s. 155-175, sum.

231. MADAJCZYK Piotr: Opolskie środowisko akademickie na tle sytuacji regionu w $1968 \mathrm{r}$. (w świetle sprawozdań miejscowych Służby Bezpieczeństwa). Studia Ślqskie. T. 63: 2004 s. 225-247, sum., Zsfg.

232. MAUERSBERG Stanisław: Nauczyciel wobec indoktrynacji komunistycznej $w$ latach 1947-1956. Prz. Hist.-Ośw. R. 47: 2004 nr 3/4 s. 53-58.

233. MEZGLEWSKI Artur: Szkolnictwo wyznaniowe w Polsce w latach 1944-1980. Studium historycznoprawne. Lublin 2004 Wydaw. KUL ss. 432. KUL. Wydz. Prawa, Prawa Kanonicznego i Admin.

234. OSIŃSKI Zbigniew: Ideologiczne uwarunkowania pracy nauczycieli w szkołach podstawowych w Polsce w latach 1957-1970. Res Historica. Z. 18: 2004 s. 57-67.

235. PAWELEC Ewa: Wzorce ideowe propagowane na łamach czasopism dla dzieci i młodzieży w pierwszej połowie lat 70. XX w. Studia. Bibl. AŚ. T. 7: 2003 s. 165-184, sum.

236. PLESKOT Patryk: Życie codzienne zagranicznych studentów na polskich uczelniach w okresie stalinizmu. Prz. Pol. R. 30: 2004 z. 2 s. 71-96, sum. s. 162.

237. SCHABIEŃSKI Jarosław, Sychowicz Krzysztof: Marzenia o orle w koronie. Nauczyciele i młodzież Polski północno-wschodniej wobec władzy w latach 1980-1986. Białystok 2004 PTH. Oddz. ss. 116.

238. SKEADANOWSKI Henryk: Walka o utrzymanie narodowego (demokratycznego) ideahu wychowawczego w polskiej oświacie w latach 1944-1947. Rocz. Hum. T. 52: 2004 z. 2 s. 57-70, sum.

239. SYCHOWICZ Krzysztof: Oświata łomżyńska w świetle materiałów Urzędu Bezpieczeństwa Publicznego. Ziemia Łomżyńska. [R.] 7: 2003 s. 247-256.

240. TERROR i konspiracja. Młodzież wobec indoktrynacji komunistycznej 1945-1956. Pod red. Elwiry Jolanty Kryńskiej. Białystok 2004 Trans Humana ss. 95, il.

Treść: [Cz.] 1: Kryńska E. J.: Słowo wstępne s. 9-14; Niktorowicz Jerzy: Pamięć - Ojczyzna - Teraźniejszość s. 15-20; Szarkowska Agnieszka: Świadomość i pamięć historyczna s. 21-24; [Cz.] 2: Milewski Jan Jerzy: Podręczniki szkolne jako środek indoktrynacji młodzieży szkolnej w Republice Białoruś s. 27-32; Kryńska E. J.: Konspiracyjne organizacje młodzieży szkół średnich (1948-1956) s. 33-42; Pruszyński Jerzy: Wspomnienia $z$ pobytu w więzieniu w Jaworznie s. 43-47; Szwagrzyk Krzysztof: Wię́niowie polityczni w systemie komunistycznego więziennictwa w Polsce 1944-1956. Doświadczenia a teraźniejszość s. 48-57; Łapiński Piotr: Skazani na karę śmierci przez Wojskowe Sądy Rejonowe w latach 1946-1955 (zarys problematyki) s. 58-73; 
Zwolski Marcin: Sytuacja „Młodocianych więźniów” w latach 1945-1956 na przykładzie więzienia w Białymstoku s. 74-82; Wróblewska Urszula: Represje systemu komunistycznego w Polsce w świetle dokumentów i fotogramów - wystawa „Zbrodnie w majestacie prawa 1944-1956” s. 85-91; Kryńska E. J.: Zakończenie. Pożądane kierunki dalszych badań s. 92-94.

241. ZWIERNIK Przemysław: Opór i działalność opozycyjna młodzieży poznańskich szkół średnich w latach 1981-1984. [W:] Stan wojenny w Wielkopolsce. Pod red. Stanisława Jankowiaka i Jana Miłosza. Poznań 2004 s. 105-123.

242. ŻUKOWSKI Anna: Odczyty pedagogiczne jako forma doskonalenia i popularyzacji doświadczeń nauczycieli rysunku w Polsce po II wojnie światowej. Prz. Hist.-Ośw. R. 46: 2003 nr 3/4 s. $85-91$.

243. ŻUREK Jacek: Powtóma kasata placówek wychowawczych Kościoła katolickiego w Polsce (1958-1963). Nasza Przesztość. T. 102: 2004 s. 193-241, sum.

\section{Okres $1989-2004$}

244. BILICKA Beata: Katecheza w polskiej szkole po 1990 roku a kultura. [W:] Katolicyzm polski na przełomie wieków. Teologiczny, instytucjonalny i wspólnotowy wymiar Kościoła. Pod red. Józefa Baniaka. Poznań 2002 s. 275-289.

245. DROZDOWICZ Zbigniew: Uczelnie, uczenie, uczeni. Poznań 2003 Kurpisz ss. 150, tabl. 32.

246. DZIUBIŃSKI Zbigniew: Kultura fizyczna w wyższych seminariach duchownych Kościoła katolickiego w Polsce. Częstochowa 2004 Educator ss. 434, il. Akad. Polonijna.

247. KARDYŚ Piotr: Nowe ustalenia z zakresu historii oświaty w Polsce średniowiecznej i ich recepcja w podręcznikach szkolnych wydawanych od 1999 roku. Prz. Hist.-Ośw. R. 46: $2003 \mathrm{nr}$ 3/4 s. 11-23.

248. SZKOLNE maski i maseczki. Rada red. Teresa Hantke [i in.]. Chorzów 2004 III Liceum Ogólnokształcące im. Stefana Batorego 8ø ss. 237, nlb. 2, tabl. XVIII.

Szkolny teatr amatorski, działający w I. 1990-2004 w Chorzowie.

249. ŚLĘZAK Monika: Szkolnictwo ukraińskie w Polsce w latach 90. XX wieku. [W:] Polska i jej wschodni sąsiedzi. T. 5. Pod red. Andrzeja Andrusiewicza. Rzeszów 2004 s. 264-283.

\section{Oświata polonijna}

250. ANANCZUK Ludmiła: Działalność klas polskich w brzeskiej Szkole Średniej nr 9. [W:] Blisko, a tak daleko. Polacy w obwodzie brzeskim na Białorusi. Red. nacz. Adam Bobryk. Warszawa 2004 s. $125-128$.

251. BONUSIAK Andrzej: Szkolnictwo polskie w Stanach Zjednoczonych Ameryki w latach 1984-2003. Analiza funkcjonalno-instytucjonalna. Rzeszów 2004 Wydaw. Uniw. Rzeszowskiego ss. 251, il., mapy.

252. CZERNIAK Irena, Lawszuk Włodzimierz: Pielęgnacja kresowej polskości: misja i dzieje „Słowa Ojczystego" - pisma oświatowego Polskiej Macierzy Szkolnej na Białorusi. [W:] Kultura 
i świadomość etniczna Polaków na Wschodzie. Tradycja i współczesność. Pod red. nauk. Antoniego Kuczyńskiego i Małgorzaty Michalskiej. Wrocław 2004 s. 251-257.

253. GADOMSKI Aleksander: Szkolnictwo polskie na Krymie. Pod red. Edwarda Walewandra. Lublin 2004 s. 157-165.

254. GRĘDZIK Agnieszka: Działalność Komitetu Pomocy Polakom na Wschodzie Kongresu Polonii Amerykańskiej Wydziału Południowa Karolina w Los Angeles na rzecz oświaty polskiej na Białorusi w latach 1989-2001. Prz. Pol. R. 30: 2004 z. 2 s. 135-142, sum. s. 163.

255. GRĘDZIK A.: Oświata i szkolnictwo polskie na Białorusi 1989-2001. Dzieje Najnowsze. R. 36: 2004 [nr] 4 s. 221-225.

256. KRASOWSKA Helena: Nauka języka polskiego we wsiach góralskich na Bukowinie. Rocz. Wsch. Nr 10: 2004 s. 214-219.

Rumunia, XIX-XXI w.

257. KUKLA Wiesław, Miszczuk Marian: Emigracyjna i polonijna prasa harcerska 1914-2003. Materiały i źródla. Warszawa 2003 Tomiko; Światowa Rada Badań nad Polonią. Komisja ds. Dziejów Harcerstwa na Obczyźnie ss. 47, nlb. 1.

258. LUBONEWICZ Aleksandra: Szkolnictwo polskie w obwodzie lwowskim na Ukrainie w latach 1992-2002. [W:] Kultura i świadomość etniczna Polaków na Wschodzie. Tradycja i współczesność. Pod red. nauk. Antoniego Kuczyńskiego i Małgorzaty Michalskiej. Wrocław 2004 s. 357-367.

259. NIR Roman: A report on the work of the SS. Cyril and Methodius Seminary for the relief of European refugee and displaced priests. Seminarians, and studens (1939-1950). Yearb. Pol. American Archives. Vol. 2: 2004 s. 271-278.

W Orchard Lake.

260. NIR R.: Pomoc Seminarium Polskiego w Orchard Lake dla uchodźców i wysiedleńców księży, seminarzystów i studentów w latach 1939-1950. [W:] Studia z dziejów Polski i Europy w XIX i XX wieku. Księga dedykowana Profesorowi Piotrowi Stefanowi Wandyczowi. Pod red. Janusza Farysia, Romana Nira i Marka Szczerbińskiego. Gorzów Wlkp. 2004 s. 127-145.

261. POLEACEC Luciana: $Z$ dziejów szkoły polskiej im. Henryka Sienkiewicza w Nowym Sołońcu (Rumunia) w latach 1870-2003. Lub. Rocz. Pedag. T. 24: 2004 s. 335-344.

262. POLSKA szkoła na tułaczych szlakach. Oprac. red. Krystyna Kubalska-Sulkiewicz. Warszawa 2004 Fundacja Archiwum Fotograficzne Tułaczy ss. 484, il., mapy.

Szkolnictwo polonijne, XX w.; tekst równol. pol., ang.

263. PYZIK Stanisław: $Z$ dziejów szkolnictwa polskiego w Argentynie. [W:] Polonia argentyńska w piśmiennictwie polskim. Antologia. Wstęp, wybór i oprac. Marta Bryszewska, Janusz Gmitruk, Jerzy Mazurek. Buenos Aires-Warszawa 2004 s. 367-377.

264. SZYMAN̉SKI Józef: Z dziejów szkolnictwa polonijnego w Belgii w okresie międzywojennym. Studia Polonijne. T. 25: 2004 s. 103-125, sum.

265. ŚWIATŁO wśród burzy. Szkolnictwo i oświata polska na Zachodzie w czasie drugiej wojny światowej. Układ, oprac. i red. nauk. Teresa Zaniewska, Norbert Pospieszny, Zygmunt Stankiewicz. Białystok 2004 Trans Humana ss. 434, nlb. 1, tabl. 16.

Materiały II międzynarodowej konferencji „Szkolnictwo i oświata polska na Zachodzie w czasie drugiej wojny światowej". 
Z treści: Kaczorowski Ryszard: Wstęp s. 19-20; Szkuta Aleksander J.: Początek szkolnictwa średniego i powszechnego w Wielkiej Brytanii w latach 1940-1941 s. 21-25; Szkuta A. J., Narębski Wojciech: Kursy Maturalne dla Żołnierzy Armii Polskiej na Wschodzie w Barbarze (Palestyna) 1943-1944 s. 26-35; Narębski W., Szkuta A. J.: Gimnazjum i Liceum Nr 1 (Alessano, Cawthorne) s. 36-48; Lisowski Witold: Junacka Szkoła Kadetów (1942-1948) s. 49-69; Dobroński Adam: III Junacka Szkoła Mechaniczna s. 70-86; Skrzypiński Henryk: Wspomnienia ucznia-żołnierza Szkoły Karpackiej w Sarnano s. 87-119; Głąb Zygmunt: Szkoła Techniczna w Ferno s. 120-131; Gruszczyński Wlodzimierz: Szkoła Handlowo-Administracyjna w Casarano (prowincja Lecce). Garść wspomnień s. 132-134; Tabędzki Tadeusz: Okruchy wspomnień z Liceum Ogólnokształcącego dla żołnierzy 2 Korpusu przy Bazie 2 Korpusu w Matino s. 135-146; Sysa Paweł: Zawodowa solidarność. Wspomnienia doktora weterynarii Andrzeja Strzeleckiego s. 147-157; Prugar-Ketling Zygmunt: Dowódcy i żołnierze. Wychowawczy dialog pokoleń s. 158-168; Kobryner Jan: Wychowanie pod Alpami - wspomnienia własne s. 169-179; Smoliński Józef: Oświata polska w Szwajcarii podczas II wojny światowej s. 180-189; Matwiejczyk Marek: Doktor Władysław Drobny [1900-1989] - przyczynek do biografii s. 190-202; Szwedek Justyna: Maurycy Marek Leykam - ppor. Jan Lewiński [ur. 1918]. Żołnierz - Architekt - Naukowiec s. 203-209; Pruszyńska Agnieszka: Polscy żołnierze, autorzy tez doktorskich Wydziału Lekarskiego Uniwersytetu w Zurychu (1944-1948). Szkice biograficzne s. 210-223; Gołębiowski Andrzej: Polskie studia Medycyny Weterynaryjnej w Zurychu w latach 1940-1946 s. 224-229; Zwierzchowski Jan: Akademickie Studia Medycyny Weterynaryjnej w Edynburgu w latach 1943-1946 s. 230-233; Matuszewska Magdalena: Studia weterynaryjne w Szkocji we wspomnieniach prof. dr. hab. Jerzego Preibischa s. 234-240; Gill Janusz: Rola profesora Eugeniusza Domańskiego w kształceniu lekarzy weterynarii w obozie jenieckim w Woldenbergu podczas II wojny światowej s. 241-248; Kobryner Teresa: Działalność dydaktyczno-wychowawcza Zgromadzenia Sióstr Nazaretanek w czasie II wojny światowej jako realizacja celów nakreślonych przez Matkę Założycielkę bł. Franciszkę Siedliską s. 249-256; Romanowska Ewa: Wspomnienia harcerek z więzień i obozów hitlerowskich na obczyźnie s. 257-264; Dąbrowsḳa Joanna: Powojenne losy Profesora Łukasza Kurdybachy s. 265-277; Kurdybacha Jacek Stanisław: Wspomnienie o moim Ojcu Profesorze dr. Lukaszu Kurdybasze s. 278-279; Gruszczyński W.: Organizacji kształcenia na uchodźstwie epizod niezwykły s. 280-284; Jara Zbigniew, Pojmańska Teresa: Profesor doktor Zbigniew Kabata, członek honorowy Polskiego Towarzystwa Parazytologicznego - w osiemdziesiąta rocznicę urodzin s. 285-290; Zaniewska T.: Strofy spod znaku karabinu i róży s. 291-298; Kamińska Janina: Karta z dziejów szkolnictwa polskiego w Niemczech po zakończeniu II wojny światowej s. 299-307; Wolter Edyta: O wychowawczym znaczeniu wartości niepodległości wewnętrznej s. 308-316; Raszkiewicz Henryk: Patriotyzm i wizje Polski w perspektywie pokolenia czynu zbrojnego w okresie II wojny światowej (próba konstrukcji w oparciu o teksty zamieszczone w „Kulturze”) s. 317-358; Szulakiewicz Wladysława: Oświata polska na Zachodzie okresu II wojny światowej w historiografii edukacyjnej lat 1972-2002. Rozważania bibliograficzne i źródłowe s. $359-369$.

266. TARKA Krzysztof: Szkolnictwo polonijne w Wielkiej Brytanii w okresie międzywojennym (1918-1939). [W:] Historia i archiwistyka. Studia z dziejów Polski, Polonii i archiwistyki. Księga dedykowana księdzu doktorowi Romanowi Nirowi. Pod red. Janusza Farysia, Dariusza A[leksandra] Rymara i Marka Szczebińskiego. Gorzów Wielkopolski 2004 s. 255-259.

267. WIERZEWSKI Wojciech A.: VIII Zjazd Nauczycieli Szkół Polonijnych w Niagara Falls, NY. Powrót do polskiego doświadczenia historycznego z lat II wojny światowej [28-31 V 2004 r.]. Athenaeum. [Vol.] 12: 2004 s. 258-264.

268. WOKÓŁ upaństwowienia polskiego gimnazjum w Orłowej. [Wyd.] Krzysztof Nowak. Pam. Ciesz. T. 19: 2004 s. 127-132.

List wicekonsula RP w Morawskiej Ostrawie Jana Bociańskiego do Naczelnika Wydz. Wschodniego MSZ w Warszawie Tadeusza Kobylańskiego z 20 II 1937 r.

269. ZAKRZEWSKA Aldona: Wychowanie obywatelskie w XII Okręgu Związku Strzeleckiego w Belgii i Francji (1927-1940). Prz. Hist.-Ośw. R. 47: 2004 nr 3/4 s. 211-223.

270. ZAKRZEWSKA A.: Wychowanie obywatelskie w XII Okręgu Związku Strzeleckiego w Belgii i Francji (1927-1940). Kwart. Pedag. R. 49: 2004 nr 4 s. 177-195. 


\section{DZIEJE SZKÓŁ RÓŻNYCH STOPNI}

\section{Szkoły podstawowe i zakłady wychowawcze}

271. BIBEK Genowefa: Historia szkoły podstawowej w Jankowie Zaleśnym. [W:] Stąd nasz ród. 1000 lat wsi Janków Zaleśny. Praca zbiorowa. Pod red. Jerzego Palpuchowskiego. Bydgoszcz-Janków Zaleśny 2004 s. 23-48.

272. CHARYSZ Elżbieta: 50 lat Zespołu Szkół nr 1 im. Komisji Edukacji Narodowej [w Nowym Sączu]. Almanach Sadecki. R. 12: 2003 nr 1 s. 3-13.

273. DZIEJE szkoły w Racocie. Praca zbiorowa. Pod red. Zbigniewa Ratajczaka. Racot 2004 Szkoła Podstawowa ss. 198, tabl. 24, mapa.

Z treści: Ratajczak Z.: Od redaktora s. 7-12; Ratajczak Z.: Racot i jego dzieje s. 13-21; Ratajczak Z: Szkoła ewangelicka w Racocie s. 22-31; Ratajczak Z.: Szkoła katolicka w Racocie s. 32-49; Ratajczak Z. Szkoła Choryń-Katarzynin s. 50-69; Wiśniewska Teresa: Szkoła w Gryżynie s. 70-90; Ratajczak Maciej: Szkoła we Wławiu s. 91-100; Ratajczak Elżbieta: Szkoła w Januszewie s. 101-109; Ratajczak Z.: Szkoła w Zglińcu s. 110-117; Ratajczak Z.: Nauka dzieci w czasie okupacji, oświata dorosłych, Szkoła Przysposobienia Rolniczego i Podstawowe Studium Zawodowe s. 118-123; Ratajczak Z.: Przytułek dla sierot wojennych z Kresów Wschodnich w Choryni s. 124-130; Ratajczak Z.: Ochronka-przedszkole w Choryni s. 131-133; Ratajczak Z.: Jak nauczyciele powiatu kościańskiego przyjęli wolność w 1918 r. s. 134-138; Ratajczak Z.: Rozbudowa szkoły w Racocie s. 139-145; Ratajczak Z.: Izba Pamięci Narodowej w szkole w Racocie s. 151-155; Hohensee Alicja: Działalność szkoły w Racocie w latach 1990-2004 s. 156-188; Kaczmarek Pawel: Szkolny Klub Sportowy „Jantar” s. 189-194.

274. FLORCZAK Grzegorz: Dzieje szkoły i historia budynku Gimnazjum nr 2 w Zawierciu. Zawiercie 2004 PUHW Axon ss. 202, il.

Lata $1907-2004$.

275. GIERLIKOWSKI Paweł: 100-letnie dzieje szkoły w Lipiej Górze, 1901-2001. Lipia Góra 2004 Tow. Przyj. Lipiej Góry i Okolic ss. 54, tabl. 10.

Zespół Szkół im. Władysława Stanisława Reymonta.

276. GŁUSZKOWSKA Jolanta, Pychowska Grażyna: 45 lat tradycji. Szkoła Podstawowa nr 153. Kronika M. Lodzi. 2003 z. 3/4 s. 126-130.

277. GROMADECKA Elżbieta, Dudczyk Janina: Zarys historii szkoły w Wielogłowach. Almanach Sqdecki. R. 12: 2003 nr 4 s. 65-76.

Od XVI w.

278. HYLA Bogumiła: Działalność dydaktyczna i kulturalno-oświatowa Szkoły Powszechnej Nr 1 w Cięcinie w latach 1918-1939. Karta Groni. Nr 21: 2001 s. 351-353.

279. KOCZ Elżbieta: Przyczynek do historii powstania i działalności szkoły w Szówsku. Rocz. SMJ. T. 15: 2002/2004 [druk.:] 2004 s. 237-242.

Od 1869 r.

280. KOŁUN Andrzej: Historia Publicznej Szkoły Podstawowej w Borzechowie. Borzechów 2004 Rada Rodziców przy Publ. Szkole Podstawowej ss. 150, il.

$\mathrm{XX}-\mathrm{XXI}$ w. 
281. KOZŁOWSKA Maria: Z historii Szkoły Podstawowej w Kleczy Zarąbkach. [W:] Klecza pod Wadowicami. Praca wydana z okazji 700-lecia wsi i 650-lecia parafii. Pod red. Tomasza Sciężora. Klecza Dolna 2004 s. 106-111.

282. MLOSTEK Urszula: Szkoła Podstawowa nr 6 w Jaworznie w latach 1912-1972. Zesz. Hist. M. Jaworzna. Z. 6: 2002 s. 25-34.

283. MONOGRAFIA Szkoły Podstawowej nr 3 w Kępnie 1951-2001. Pod red. Włodzimierz Mazurkiewicz. Kępno 2001 Wydaw. Tygodnika Kępińskiego „Pismak” ss. 149, il.

Z treści: Dzieje szkoły w latach 1951-2001 s. 7-58; Grono pedagogiczne, pracownicy i współpracownicy szkoły s. 79-86; Absolwenci Szkoły Podstawowej nr 3 s. 87-144.

284. NASZA szkoła. Historia i współczesność. Praca zbiorowa. Pod red. Józefy Brani, Joanny Fabin, Małgorzaty Simik. Spytkowice 2004 Zespół Szkół w Spytkowicach ss. 240, il.

Z treści: Rok jubileuszowy s. 6-62; Przeszłość i teraźniejszość s. 73-154; Bodzenta Józef: Z dziejów szkoły w Spytkowicach s. 173-187; Chlebicka Bernadeta, Fraś Teresa: Listy absolwentów 1955-2004 s. 197-216.

285. NOWAK Tomasz Andrzej: Z dziejów szkoły elementarnej w Radomsku. Ziemia Częstochowska. T. 30: 2003 s. 121-145.

XVIII-XIX w.

286. RACHWALSKA Katarzyna: Powstanie i rozwój Szkoły Podstawowej nr 2 w Żywcu. Karta Groni. Nr 22: 2003 s. 103-120.

Lata 1867-1939.

287. RATAJCZAK Zbigniew: Przytułek dla sierot wojennych z Kresów Wschodnich w Choryni. Pam. TMZK. T. 11: 2001/2004 [druk.:] 2004 s. 63-69.

Działał od 5 XII 1918 r. do pocz. roku szkolnego 1930/31.

288. RYŁKO Andrzej: Rycerka Dolna - historia szkoły na tle rozwoju miejscowości. Karta Groni. Nr 21: 2001 s. 175-179.

XVII-XX w.

289. RYŁKO Jolanta: Historia szkoły w Rajczy od czasów najdawniejszych do 1945 r. Karta Groni. Nr 21: 2001 s. 180-183.

Od $1843 \mathrm{r}$.

290. SĘK Grażyna: Szkoła w Lętowicach wczoraj i dziś. Lętowice 2004 Szkoła Podstawowa im. Tadeusza Kościuszki ss. 192, il.

XIX-XXI w.

291. [STO] 100 lat. 1902-2002. Szkoła Podstawowa nr 2 z Przedszkolem im. Królowej Jadwigi w Niechobrzu. Zespół red. Halina Chwalik, Magdalena Misiak, Elżbieta Kręglielewska, Bronisława Żołdak. Niechobrz 2002 Urząd Gminy w Boguchwale ss. 88, tabl. 20.

292. [STO dwadzieścia] 120 lat szkoły w Orzechówce. Praca zbiorowa. Orzechówka 2004 Zespół Szkół ss. 232, tabl. 24.

Z treści: Glazer Małgorzata: Z dziejów Orzechówki s. 7-42; Boroń Zofia, Mazur Ewa, Gurgacz Ewa: Historia szkoły s. 43-187; Boron Z.: Grono pedagogiczne szkoły w Orzechówce s. 188-194; Wspomnienia. Materiał zebrała E. Mazur s. 195-224.

293. TRZEBUNIANIE... o sobie. Życie, ludzie, kultura, historia. Pcim 2004 Gminny Ośr. Kultury; Urząd Gminy ss. 238, tabl. 8. 
Z treści: Adamczyk Jan: Historia szkoły w Trzebuni w latach 1875-1962 s. 199-204; Łatas Stanisława: Hjstoria szkoły w Trzebuni od 1965 do chwili obecnej s. 205-214; Losy wybranych absolwentów szkoły w Trzebuni. Sporządził Grzegorz Bielecki na podstawie tablicy ze Szkoły Podstawowej s. 215-218.

\section{Szkoły średnie ogólnokształcące}

294. BAŚNIE i legendy drugiej budy. (Wspomnienia wybrane). [Wybór i red.] Leszek Bolanowski. Nowy Sącz 2003 Wydaw. Leszek Bolanowski; II Liceum Ogólnokształcące im. M. Konopnickiej ss. 238 , il.

Antologia wspomnień poświęconych II Liceum Ogólnokształcącemu im. M. Konopnickiej w Nowym Sączu.

295. BUDYNEK Marcin: XXV Liceum Ogólnokształcące im. Stefana Żeromskiego w Łodzi zarys dziejów. Rocz. Lódz. T. 50: 2003 s. 191-217.

$\mathrm{XX}$ w.

296. DUDZIK Maria: „Szkoło, gdy Cię wspominam...”. Goniec Kresowy. Nr 41: 2003 s. 19-21.

Nauka w Państwowym Gimnazjum w Buczaczu od 1934 r.

297. GAŃCZYK Barbara: Drugi dzwonek. Alfabetyczny informator o Liceum Ogólnokształcącym w Kłodawie 1953-2003. Kłodawa-Konin 2004 LO; Drukarnia Braci Wielińskich ss. 375, il.

298. HALOR Antoni: Nasza buda. Szkice z historii I-go Liceum Ogólnokształcącego im. Jana Śniadeckiego w Siemianowicach Śl[ąskich]. Siemianowice Śląskie 2004 Urząd Miasta ss. 152, il. (Biblioteka Siemianowicka. Z. 10).

$\mathrm{XX}$ w.

299. KLIMA Jadwiga: Szkoła żeńska Panien Benedyktynek $w$ Staniątkach $w$ latach 1869-1953. Rocz. Bibl. Nauk. PAU i PAN w Krakowie. R. 49: 2004 s. 317-336, sum.

300. KOMARZYNIEC Grażyna: Nauczanie matematyki w krakowskiej Szkole Nowodworskiej w latach 1588-1914. Kraków 2004 Wydaw. Nauk. AP ss. 221, nlb. 3, il. Akad. Pedagog. im. KEN w Krakowie. (Prace Monograficzne. Nr 384).

I Liceum Ogólnokształcące im. Bartłomieja Nowodworskiego w Krakowie.

301. KONTOWT-OKULEWICZOWA Irena, Kalenkiewicz-Mirowiczowa Anna Krystyna: Państwowe Gimnazjum im. św. Kazimierza w Nowej Wilejce. Wspomnienia. Pod red. Leszek Jan Malinowski. Bydgoszcz 2003 Tow. Miłośn. Wilna i Ziemi Wileńskiej ss. 184, il., mapa. (Biblioteka Wileńskich Rozmaitości. Seria B nr 48).

Pamiętniki z 1. 1918-1945.

302. KOWALCZUK Jerzy: II (druga) Szkoła Realna we Lwowie (lata szkolne 1903/1904-1920/1921). Kraków 2003 Jerzy Kowalczyk ss. CCX, 190, nlb. 1, il., sum. (Szkoły Lwowskie: Monografie. Historia Szkolnictwa, Oświaty i Wychowania na Ziemiach Odłączonych II Rzeczypospolitej - Kresach Południowo-Wschodnich. T. 1 cz. B: Szkoły Lwowskie).

303. KOWALCZUK J.: Wyższa Szkoła Realna we Lwowie i jej przekształcenia (lata szkolne: 1873/1874-1920/1921). Kraków 2002 Jerzy Kowalczyk ss. CXXXII, 323, il., sum. (Szkoły Lwowskie: Monografie. Historia szkolnictwa, oświaty i wychowania na ziemiach odłączonych II Rzeczypospolitej - Kresach Południowo-Wschodnich. T. 1 cz. A: Szkoły Lwowskie). 
304. KOZIELSKI Marian: Jak doprowadziłem Profesora Kudasika do zawału serca. Almanach Nowotarski. Nr 8: 2004 s. 114-127.

Wspomnienia z nauki w liceum i o szczególnej w nim roli polonisty Andrzeja Kudasika (1935-2003).

305. KRAWCZYŃSKA Anna: I Liceum Ogólnokształcące im. Piotra Skargi w Pułtusku w latach 1990-2000. (Szkic do dziejów). Lublin 2004 Lubelskie Centrum Marketingu ss. 67, nlb. 1, il.

306. KRZEMIENIEC. Ateny Juliusza Słowackiego. Pod red. Stanisława Makowskiego. Warszawa 2004 Wydaw. BN ss. 588, tabl. 20. BN, Tow. Liter. im. Adama Mickiewicza, Wydz. Polonistyki Uniw. Warszawskiego.

Z treści: Chodakowska Janina: Gimnazjum i Liceum Wołyńskie w Krzemieńcu (1805-1832) s. 9-27; Danilewiczowa Maria: Życie naukowe dawnego liceum krzemienieckiego s. 28-53; Hoffmann-Piotrowska Ewa: Matematyka i matematycy w szkole krzemienieckiej s. 54-61; Affek Mariusz: Tadeusz Czacki [1765-1813] organizator Gimnazjum Wolyńskiego w Krzemieńcu s. 62-74; Żbikowski Piotr: Hugo Kolłątaj [1750-1812] współtwórca Gimnazjum Wołyńskiego w Krzemieńcu s. 75-92; Szczeglacka Ewa: Teodozy Sierociński [1789-1857] - uczeń i nauczyciel krzemieniecki s. 231-236; Kamińska Anna Elżbieta: Józef Korzeniowski [1797-1863] - uczeń i nauczyciel liceum krzemienieckiego s. 237-252.

307. KSIĘGA jubileuszowa 100-lecia szkoły 1904-2004. Szkoła Realna, Państwowe Gimnazjum, Liceum Ogólnokształcące, Zespół Szkół Ogólnokształcących im. Mikołaja Kopernika w Żywcu. Pod red. Aleksandry Bury i Krystyny Bury; przy wspólpr. Izabeli Czerwoniak i Heleny Kupczak. Żywiec 2004 Kom. Organizacyjny Obchodów Jubileuszu 100-lecia Szkoły w Zespole Szkół Ogólnokształcących im. Mikołaja Kopernika ss. 320, nlb. 2, il.

Z treści: Słowik-Tyc Halina: O ksiegach rocznicowych naszej szkoły - krótkie przypomnienie treści s. 15-21; Czerwoniak I., Kupczak H.: Ważniejsze wydarzenia w życiu szkoły - lata 1893-1939 s. 25-34; Kosiński Rafał: Dzieje szkoły w latach 1939-2004 s. 35-100; Zyzak Władysław: Wspomnienia ucznia c.k. Szkoły Realnej w Żywcu z lat 1904-1913 s. 103-138; Skwirut Władysław: Bronisław Gustawicz (1852-1916) - wybitny przedstawiciel polskiego scjentyzmu s. 175-179; Jeziorski Ireneusz: Nachman Hirsch Bau jako „swój obcy” - kilka słów o rabinie żywieckiego gimnazjum s. 179-181; Spyra Eugenia: Ksiądz Leopold Kisielewski - wybitna osobowość s. 182-183; Janik Stanisława B.: Pani Dyrektor Zofia Hebenstreit s. 183-184; Janik Jan: Życiorys Stanisławy Barbary Jeziorskiej-Janik s. 185-186; Caputa Michał: Marian Kuziak - wspomnienia w rocznice śmierci s. 187-191; Czerwoniak I.: Czesław Oboza - matematyk i kierownik internatu w latach 1955-1968 s. 191-193; Porwisz Stanisław: Wspomnienia Dyrektora Liceum w latach 1969-1971 s. 193-195; Janik J.: Dyrektor Jerzy Swwisterski (1931-2000) s. 196-197; Kupczak Helena: Wspomnienie o Pani Profesor Marii Janosz s. 197-198; Janik J.: Profesor Henryk Żywotko s. 200-202; Rościszewski Krzysztof: Zdrowy rozsądek szkoły s. 213-232; Nauczyciele i pracownicy szkoły 1904-2004 s. 233-248; Absolwenci Szkoły Realnej, Państwowego Gimnazjum, Liceum Ogólnokształcącego, I Liceum Ogólnokształcącego w Zespole Szkół Ogólnokształcących im. Mikołaja Kopernika w Żywcu s. 249-308; Absolwenci Liceum Ogólnokształcącego dla Pracujących, Liceum Ogólnokształcącego dla Dorosłych w Zespole Szkół Ogólnokształcących im. Mikołaja Kopernika w Żywcu s. 309-318.

308. MIĄSO Józef: Gimnazjum Realne w Warszawie (1841-1862). [W:] Wokół historii i polityki. Studia z dziejów XIX i XX wieku dedykowane profesorowi Wojciechowi Wrzesińskiemu w siedemdziesiątą rocznicę urodzin. Pod red. Stanisława Ciesielskiego, Teresy Kulak, Krzysztofa Ruchniewicza i Jakuba Tyszkiewicza. Toruń 2004 s. 547-556.

309. MŁODZIEŃCZY lot. Dzieje Państwowego Żeńskiego Gimnazjum i Liceum nr 39 im. Emilii Sczanieckiej w Lodzi w latach 1920-1939. Praca zespołowa. Pod red. Janiny Gołębiewskiej-Grzelczak. Łódź 2001 IV Liceum Ogólnokształcące im. Emilii Sczanieckiej; Warsztaty Szkolne Zespołu Szkół Papierniczo-Poligraficznych ss. 162, il., mapa.

310. MY z „Marcinka”. Matura 1951. Zespół red. Mieczysław Feglerski [i in.]. Poznań 2004 J. M. Stefko ss. 318 , il.

Antologia wspomnień absolwentów Liceum im. Karola Marcinkowskiego w Poznaniu. 
311. PIĄTKA na piątkę. 50 lat Liceum Ogólnokształcącego im. Wladysława Broniewskiego w Katowicach-Ochojcu. Szkic monograficzny. Pod red. Ewy Żurawskiej. Katowice 2004 Verso ss. 159, il.

Z treści: Pół wieku historii szkoły s. 9-28; Osiągnięcia uczniów s. 35-44; Galeria znanych absolwentów s. 45-52; Nie samą nauką uczeń żyje s. 53-82; Portret nauczyciela - osobowość ucznia. Klimat szkoły, czyli Piatka we wspomnieniach s. 83-117; Grono nauczycielskie i administracja szkoły na przestrzeni 50 lat s. 119-124; Absolwenci 50-lecia s. 125-157.

312. PUDŁOCKI Tomasz: Blask szarości... Życie codzienne w I Państwowym Gimnazjum im. Juliusza Słowackiego w Przemyślu w latach 1918-1939. Przemyśl 2004 Regionalny Ośr. Kultury, Edukacji i Nauki ss. 264, il., sum.

313. SALEZJAŃSKIE Liceum Ogólnokształcące im. Henryka Sienkiewicza w Sokołowie Podlaskim. Dziesięć lat działalności wychowawczej i dydaktycznej (1993-2003). Zespół red. Piotr Boczula [i in.]. Sokołów Podlaski 2003 Fundacja Ku Mądrości im. dr Anny Dux ss. 156, il., sum., Zsfg.

314. SZABUŃKO Jolanta: Nie zatrzeć pamięci. Ziemia Lomżyńska. [R.] 7: 2003 s. 104-109.

I Liceum Ogólnokształcące im. Tadeusza Kościuszki w Łomży w XX w.

315. SZKOŁA św. Marii Magdaleny w Poznaniu. Pod red. Grzegorza Łukomskiego. Poznań 2002 „Bene Nati” - Jadwiga Wolarska ss. 330.

W 1. 1302-2002.

316. TEN jest ze szkoły naszej... W 90-lecie Koła Wychowanków i Wychowanek Szkół Średnich Ogólnokształcących w Łowiczu. Kom. red. Henryk Zasępa [i in.]. Łowicz 2004 Poligrafia; Koło Wychowanków i Wychowanek Szkół Średnich Ogólnokształcących ss. 168, il.

Treść: Zaseppa H.: Historia Koła Wychowanków do wojny s. 5-26; Zasepa H.: Zjazdy koleżeńskie do wojny s. 27-42; Zasępa H.: Akademickie Kolo Lowiczan s. 43-77; Flisowska Maria: Pierwsze lata powojenne s. 78-115; Niebudek Zbigniew: Na przelomie dziejów s. 116-125; Wróbel Jolanta: Ostatnia dekada s. 126-150; Koleżanki i koledzy, którzy pełnili różne funkcje we władzach Koła Wychowanków i Wychowanek Szkół Średnich Ogólnokształcących w Lowiczu w latach 1958-2004 s. 151-157; Tablice ufundowane przez koło Wychowanków s. $158-162$.

317. URBANKIEWICZ Jerzy: Takiej szkoły się nie zapomina. Gimnazjum Aleksego Zimowskiego. Kronika M. Łodzi. 2003 z. 3/4 s. 120-125.

Wspomnienia nestora łódzkich dziennikarzy $\mathrm{z}$ lat szkolnych.

318. WALISZEWSKI Stanisław: Gimnazjalne miraże. Dopełnienia. Rogoźno 2004 Tow. Przyj. Rogoźna ss. 75, il. (Biblioteka Rogozińskich Zeszytów Historycznych. Nr 2).

Stanowi kontynuację książi: Gimnazjalne miraże. Wspomnienia. Rogoźno 2001.

319. WÓJCIK Zbigniew K.: Profesorowie i uczniowie I Gimnazjum w Rzeszowie represjonowani za postawę i dzialalność antykomunistyczną (1944-1956). Zesz. Hist. WiN-u. R. 13: 2004 nr 21 s. $265-298$.

320. ZANIEWSKA Teresa: Hrabiowski biały dom. Gimnazjum w Sterdyni 1942-1950. Białystok 2004 Trans Humana ss. 345, nlb. 3, tabl. 18.

Rec.: Lewandowska Stanisława, Rocz. Maz. T. 16: 2004 s. 310-312.

321. ZŁOTA Piątka. Pokolenie wielkiej próby. Dzieje 5. Warszawskiej Drużyny Harcerzy przy gimnazjum i liceum im. Joachima Lelewela. Ze wspomnień i dokumentów. Red. t. Henryk Spigarski; wyd. Hanna, Zofia i Piotr Kuropatwińscy. Warszawa-Gdańsk 2004 Fundacja Promocji Przemysłu Okrętowego i Gospodarki Morskiej ss. 223, il., mapa.

Z treści: Patron Szkoły - Joachim Lelewel s. 6; Pierwszy patron drużyny - Zygmunt F. Miłkowski s. 7; Cz. 1: Okres niepodległości lata 1920-1939 s. 8-49; Cz. 2: Najdłuższe lata s. 50-93; Cz. 3: W dywersji i w po- 
wstaniu s. 94-169; Cz. 4: Biogramy wybranych harcerzy i instruktorów 5 WDH im. płk. Zygmunta Miłkowskiego, od 1937 hm. Henryka Dąbrowskiego s. 170-201; 5 WDH im. płk. Zygmunta Miłkowskiego, od 1937 roku im. hm. Henryka Dąbrowskiego s. 204-219.

\section{Szkoły zawodowe}

322. CHMIEL Stanisław: Szkoła życia Wandy Popławskiej [1883-1952]. Końskowola-Sitno 2004 Woj. Ośr. Doradztwa Rolniczego. Gospodarstwo Pomocnicze. Oddz. ss. 136, nlb. 2, tabl. 24. Lubelski Woj. Ośr. Doradztwa Rolniczego w Końskowoli. Oddz. w Sitnie.

Dyrektorka Ludowej Szkoła Rolniczej Żeńskiej w Sitnie (woj. lubelskie).

323. [CZTERDZIEŚCI] 40 lat minęło... Od Technikum Mechanicznego do Zespołu Szkół Technicznych w Pleszewie 1963-2003. Praca zbiorowa wydana z okazji 40-lecia szkoły. Red. merytoryczny Dorota Czaplicka, Róża Dzierbińska-Nowacka. Pleszew 2003 Zespół Szkół Technicznych ss. 150 , nlb. 1, tabl. 20.

Z treści: Cichy Dariusz, Waliszewski Janusz: Historia szkoły przy ulicy Zielonej s. 9-28; Grzybkowka Jolanta: Skarbiec, czyli rzecz o osiagnięciach s. 29-49; Trzeciak Ireneusz, Kałużna Barbara, Kowalska Krystyna: Kształcenie praktyczne s. 50-90; Cichy D., Waliszewski J.: Pracownicy szkoły s. 125-138.

324. KLASA Pani Irminy. Historia $z$ lat 1955-59 w Technikum Chemicznym w Pionkach. [Wyd.] Wiesław Nosowski. Pionki-Warszawa 2004 BelStudio ss. 132, il.

Wspomnienia uczniów Irminy Marii Brzezickiej (ur. 1931).

325. KRYSIAK Marian Piotr: 50 lat Szkoły Policji w Pile 1954-2004. Piła 2004 Szkoła Policji ss. $187, \mathrm{il}$.

326. NOWAĆ Bronisław: Garść wspomnień wychowanka Szkoły Rolniczej w Zwoleniu. Oprac. Przemysław i Stanisław Zielińscy. Wies Radomska. T. 6: 2001 s. 225-258.

Wspomnienia absolwenta z 1934 r.

327. OBRONA krzyża w Miętnem. Wspomnienia, dokumenty, relacje. Red. Anna Wasak; oprac. red. Bogumil Wawer. Radom 2004 Pol. Wydaw. Encyklopedyczne ss. 203, il.

Zespół Szkół Rolniczych im. Stanisława Staszica w 1. 1980-1989.

328. OLĘDER Stanisław: W Szkole Spółdzielczo-Handlowej w Kozienicach. Wieś Radomska. T. 6: 2001 s. $277-286$.

Wspomnienia autora (ur. 1919) z nauki w 1. 1934-1937.

329. PAŃSTWOWE Centrum Wychowania Morskiego. Szkoła Jungów 1946-1951. Mater. zebr. i oprac. Roman Watras. Gdynia 2004 Wydaw. Akad. Morskiej ss. 459, il., mapy.

Z treści: Lisowski Józef: Od Rektora Akademii Morskiej w Gdyni s. 5-6; Watras R.: Przedmowa s. 7-8; Figiela Józef: Refleksje nad ksiazzką s. 9-10; Cz. 1. Szkoła Jungów w świetle dokumentów i relacji jej twórców: Statut Państwowego Centrum Wychowania Morskiego (PCWM). [1946 r.] s. 13-23; Państwowe Centrum Wychowania Morskiego 1946-1951 s. 25-34; Michałowski Józef B[olesław]: Państwowe Centrum Wychowania Morskiego (PCWM) s. 35-37; Michałowski J. B.: O pracy prof. dr. Kazimierza Kubika pt. „Paŕstwowe Centrum Wychowania Morskiego" s. 39-52; Wierzbicki Franciszek: Szkoła Jungów s. 53-62; Perepeczko Andrzej: Szkoła Jungów w świetle ocalałych dokumentów, przepisów i wymagań s. 63-78; Wawrykiewicz Janusz: Państwowa Szkoła Jungów - utworzenie warsztatów szkolnych s. 79-84; Watras R.: Dyrektor Państwowego Centrum Wychowania Morskiego Józef Bolesław Michałowski s. 85-87; Watras R.: Kpt. ż.w. Michał Leszczyński „Pigłu” s. 89-96; Duda Daniel: Druh hm. mgr Stanisław Ludwig - wychowawca wielu z nas s. 97-101; Ludwig S.: Wspomnienia s. 103-118; Duda D.: Franciszek Michał Wierzbicki (1914-1996) i jego wkład w rozwój szkolnictwa morskiego s. 119-132; Piątkowski Henryk: Wspomnienia z działalności w Lidze Morskiej 
s. 133-141; Duda D.: Redaktor Jerzy Miciński (1921-1995) s. 143-149; Wawrykiewicz J.: Edmund Jankowski s. 151-153; Redaktor Henryk Kabat (1914-2003) s. 155-157; Duda D.: Witold Bublewski - nestor gospodarki morskiej i wychowania morskiego s. 159-168; Cz. 2. Wspomnienia absolwentów Szkoły Jungów w Gdyni s. 193-420; Państwowe Centrum Wychowania Morskiego w Gdyni. Absolwenci Szkoły Jungów 1946-1951. (Oprac. R. Watras) s. $421-435$.

330. PLOCH Kazimierz: Państwowe Liceum Felczerskie w Krakowie w latach 1951-1958. Rocz. Kom. Nauk Pedag. T. 57: 2004 s. 33-64, r,s.

331. RÓŻAŃSKI Maciej: Szkoła z tradycjami - 55 lat Zespołu Szkół Drzewnych i Leśnych w Żywcu. Karta Groni. Nr 21: 2001 s. 184-188.

Lata 1946-2001.

332. SZNAJDER Piotr: Wspomnienia nauczyciela Szkoły Rolniczej w Zwoleniu. Oprac. Przemysław i Stanisław Zielińscy. Wieś Radomska. T. 6: 2001 s. 259-276.

Z 1. 1934-1939.

333. WALKA o krzyże. Miętne-Włoszczowa 1984. Wybór, oprac. i red. Tadeusz Krawczak, Cyprian Wilanowski. Warszawa 2004 Pax ss. 253, nlb. 3, tabl. 16. (Z Najnowszej Historii Kościoła).

Zespół Szkół Rolniczych im. Stanisława Staszica w Miętnem i Zespół Szkół Zawodowych we Włoszczowej.

334. WOJTAS Jacek: 80 lat Szkoły Ekonomicznej w Jarosławiu (1924-2004). Rocz. SMJ. T. 15: 2002/2004 [druk.:] 2004 s. 209-216.

335. WOLSAN Stanisław: Szkoła Mleczarska w Rzeszowie 1903-2003. T. 2. Rzeszów 2004 Poligrafia Wyższego Seminarium Duchownego s. nlb. 5, 212-558, tabl. 62.

Toż. T. 3: Indeksy nazwisk. ss. nlb. 4, 563-710.

T. 1. 2003.

336. ZESPÓŁ szkół ponadgimnazjalnych im. ks. Henryka Mrossa w Gniewie. Oprac. Krzysztof Gurbowicz. Gniew-Pelplin 2004 Bernardinum ss. 102, nlb. 2, tabl. 15.

Z treści: Gurbowicz K.: Patron szkoły s. 7-14; Gurbowicz K.: Historia szkoły s. 21-42; Byli pracownicy ZSP i ZSZ s. 55-58; Absolwenci s. 59-102.

\section{Zakłady kształcenia nauczycieli \\ (z wyjątkiem szkól wyższych)}

337. DUDA Jerzy: Państwowe Seminarium Nauczycielskie Męskie im. Henryka Sienkiewicza w Tarnopolu w latach 1871-1936. Prz. Hist.-Ośw. R. 46: 2003 nr 3/4 s. 199-215.

338. Z KART historii i pamięci Liceum Pedagogicznego w Zawierciu 1945-1971. Opracowanie zbiorowe. Zespół red. Krystyna Ciupa [i in.]. Zawiercie 2004 Axon ss. 388, il.

\section{Szkoły wyżse}

\section{Akademia Bydgoska}

339. JASTRZĘBSKI Włodzimierz: 15-lecie studiów historycznych na Akademii Bydgoskiej im. Kazimierza Wielkiego. Kronika Bydgoska. T. 25: 2003 [druk.:] 2004 s. 365-379. 


\section{Akademia Ekonomiczna w Krakowie}

340. STECZKOWSKI Jan: Dwadzieścia pięć lat Zakładu Statystycznych Metod Kontroli Jakości w Akademii Ekonomicznej w Krakowie, 1978-2003. Folia Oeconomica Cracoviensia. Vol. 43/44: 2000-2003 [druk.:] 2004 s. 81-90.

\section{Akademia Ekonomiczna we Wroclawiu}

341. [TRZYDZIESCI] XXX lat Instytutu Informatyki Ekonomicznej Akademii Ekonomicznej im. Oskara Langego we Wrocławiu. Red. t. Elżbieta Niedzielska, Adam Nowicki. Wrocław 2004 Wydaw. Akad. Ekonomicznej im. Oskara Langego ss. 139, il.

Treść: Niedzielska E.: Początki informatyki na uczelni s. 13-22; Nowicki Adam: Powstanie i zmiany organizacyjne instytutu s. 23-33; Małachowski Andrzej, Niedzielska E., Nowicki A.: Kierunki badań naukowych s. 37-55; Niedzielska E., Rot Artur: Doktoraty i habilitacje s. 56-61; Dydaktyka s. 65-75; Wybrane publikacje naukowe s. 77-110; Konferencje s. 113-116; Kadra Instytutu s. 118-139.

\section{Akademia Górniczo-Hutnicza}

342. KLECZKOWSKI Antoni Stanisław: Studia nad przeszłością Akademii Górniczo-Hutniczej im. Stanisława Staszica w Krakowie. Kraków 2004 Uczelniane Wydawnictwa Nauk.-Dydaktyczne AGH ss. 200, nlb. 1, il., mapy.

Rec.: Wójcik Zbigniew, Zesz. Staszicowskie. Z. 4: 2004 s. 305-308.

\section{Akademia Medyczna im. Karola Marcinkowskiego}

343. MAJEWSKA Anna C.: Dzieje Katedry i Zakładu Biologii i Parazytologii Lekarskiej. Akademia Medyczna im. Karola Marcinkowskiego w Poznaniu (1922-2002). [W:] Dzieje parazytologii polskiej w latach 1945-2000. Pod red. Elżbiety Lonc, Bożeny Plonka-Syroki. Wrocław 2004 s. 91-141.

\section{Akademia Medyczna im. Ludwika Rydygiera}

344. AKADEMIA Medyczna im. Ludwika Rydygiera w Bydgoszczy: 1984-2004. Pod red. Krzysztof Nierzwicki. Bydgoszcz 2004 Akad. Medyczna im. Ludwika Rydygiera ss. 384, il,, mapy, sum.

Z treści: Zyglewski Zbigniew: Dzieje Bydgoszczy s. 7-10; Domaniewski Jan: Historia Akademii Medycznej s. 11-34; Janowicz Eugeniusz: Ludwik Rydygier s. 35-38; Rektorzy s. 39-46; Kubiak Monika: Doktorzy honoris causa s. 47-61; [Działalność] s. 65-108; Wydziały s. 111-324; Studenci s. 325-336.

\section{Akademia Medyczna im. Piastów Śląskich}

345. BRUSIEWICZ-MIKLASZEWSKA Barbara, Wojtowicz Małgorzata: Uniwersytecki Instytut Dentystyczny we Wrocławiu w latach 1890-2003 i związany z nim reprezentacyjny gmach przy ulicy Antoniego Cieszyńskiego 17-19. Rocz. Wroct. [T.] 9: 2004 s. 83-101, Zsfg. 


\section{Akademia Medyczna we Wroclawiu}

346. HISTORIA Wydziałów Lekarskiego i Farmaceutycznego Uniwersytetu Wrocławskiego oraz Akademii Medycznej we Wrocławiu w latach 1702-2002. Geschichte der Medizinischen und Pharmazeutischen Fakultäten der Universität Breslau sowie der Medizinischen Akademie Wrocław in den Jahren 1702-2002. Pod red. Waldemara Kozuschka. Wrocław 2002 Wydaw. Uniw. Wrocławskiego ss. 419, il. (Acta Universitatis Wratislaviensis. No 2434).

$\mathrm{Z}$ treści: Gelles Romuald: Słowo wstępne Rektora Uniwersytetu Wrocławskiego. Vorwort des Rektors der Universität Wrocław s. 6-10; Kozuschek W.: Początki szkolnictwa medycznego we Wrocławiu: „Theatrum anatomicum" i Szkoła Medyczno-Chirurgiczna do 1849 roku. Die Anfänge des medizinischen Unterrichts in Breslau: „Theatrum anatomicum” und die Medizinisch-Chirurgische Lehranstalt bis 1849 s. 16-43; Kozuschek W.: Wydział Medyczny Uniwersytetu Wrocławskiego w latach 1811-1945. Die Medizinische Fakultät der Universität Breslau der Jahre 1811 bis 1945 s. 44-155; Kozuschek W.: Dzieje Studium Farmaceutycznego Uniwersytetu Wrocławskiego do 1945 roku. Die Entwicklung des Pharmazeutischen Studiums an der Universität Breslau bis 1945 s. 156-167; Rozwój medycyny i farmacji Uniwersytetu Wrocławskiego (1945-1949) oraz Akademii Medycznej we Wrocławiu (1950-2002). Die Entwicklung der Medizin und Pharmazie an der Universität Wrocław (1945-1949) und an der Medizinischen Akademie in Wroclaw (1950-2002): Jagielski Józef: Podstawowe nauki medyczne. Medizinische Grundlagenfächer s. 174-211; Heimrath Tadeusz, Knapik Zbigniew: Medycyna kliniczna. Klinische Medizin s. 212-311; Bruziewicz-Miklaszewska Barbara: Stomatologia. Zahnmedizin s. 312-341; Pluta Janusz, Syroka Andrzej: Oddział Farmaceutyczny Uniwersytetu Wrocławskiego (1945-1949) i Wydział Farmaceutyczny Akademii Medycznej we Wrocławiu (1950-2002). Pharmazeutische Abteilung der Universität Wroclaw (1945-1949) und Pharmazeutische Fakultät an der Medizinischen Akademie in Wroclaw (1950-2002) s. 342-365; Wójtowicz Małgorzata: Architektura zespołu klinik i instytutów dawnego Wydziału Medycznego Uniwersytetu Wrocławskiego. Architektur des Klinik- und Institutskomplexes der ehemaligen Medizinischen Fakultät der Universität Breslau s. 368-389.

\section{Akademia Muzyczna im. F. Chopina}

347. GRONAU-Osińska Alicja: Rytmika w Akademii Muzycznej im. F. Chopina w Warszawie. T. 1: Lata 1974-1988. Warszawa 2004 Wydaw. AM im. F. Chopina ss. 357, il., nuty. Akad. Muzyczna im. F. Chopina w Warszawie. Katedra Edukacji Muzycznej.

\section{Akademia Polocka}

348. KADULSKA Irena: Akademia Połocka. Ośrodek kultury na Kresach 1812-1820. Gdańsk 2004 Wydaw. Uniw. Gdańskiego ss. 308, nlb. 4, tabl. 12, mapy., sum., res.

\section{Akademia Rolnicza w Lublinie}

349. KSIĘGA pamiątkowa. 60-lecie Wydziału Medycyny Weterynaryjnej. Oprac. Krzysztof Szkucik, Andrzej Wernicki. Lublin 2004 Wydaw. Akad. Rolniczej ss. 242, il.

Z treści: Wernicki A., Grądzki Zbigniew: Osiagnięcia lubelskiego Wydziału Medycyny Weterynaryjnej s. 7-20; Działalność jednostek naukowo-dydaktycznych s. 23-193; Horyza Karol: Organizacje studenckie s. 194-196; Absolwenci lubelskiego Wydziału Weterynaryjnego - samodzielni pracownicy nauki w innych placówkach badawczych s. 204-205; Absolwenci Wydziału w latach 1946-2003 s. 206-239. 
350. KSIĘGA pamiątkowa: 60-lecie Wydziału Rolniczego. Oprac. Edward Pałys, Marian Wesołowski. Lublin 2004 Wydaw. Akad. Rolniczej ss. 352, ił.

Z treści: Wesołowski M., Pałys E.: Historia i osiągnięcia Wydziału Rolniczego Akademii Rolniczej w latach 1944-2004 s. 7-35; Działalność jednostek naukowo-dydaktycznych s. 58-245; Zmarli nauczyciele akademiccy s. 254; Absolwenci s. 255-350.

\section{Akademia Rolnicza w Szczecinie}

351. [PIEĆCDZIESIĄT] 50 lat Wydziału Kształtowania Środowiska i Rolnictwa Akademii Rolniczej w Szczecinie. Pod red. Stanisława Dzieni. Szczecin 2004 Akad. Rolnicza ss. 199.

\section{Akademia Zamojska}

352. GMITEREK Henryk: Młodzież z województwa lubelskiego w Akademii Zamojskiej (1595-1784). Próba ujęcia statystycznego. Res Historica. Z. 17: 2004 s. 145-151.

\section{Katolicki Uniwersytet Lubelski}

353. IWASZKIEWICZ-WRONIKOWSKA Bożena: Pół wieku Katedry Historii Sztuki Starożytnej i Wczesnochrześcijańskiej w Katolickim Uniwersytecie Lubelskim. Rocz. Hum. T. 51: 2003 z. 4 s. $7-18$, sum.

354. PIATEK Jan: 10 lat Świętokrzyskiego Instytutu Teologicznego w Kielcach przy Wydziale Teologii KUL. Kielce 2003 Jedność ss. 144, il.

\section{Państwowa Wyższa Szkoła Zawodowa w Koninie}

355. KAPYSZEWSKA Ewa, Zimny Artur: Państwowa Wyższa Szkoła Zawodowa w Koninie w latach 1998-2003. Konin 2003 Wydaw. Państ. Wyższej Szkoły Zawodowej ss. 177, il.

\section{Państwowa Wyższa Szkola Zawodowa w Sulechowie}

356. MILEK Marian, Świtała Bogusław: Państwowa Wyższa Szkoła Zawodowa w Sulechowie. Od Steibarta po czasy współczesne. Tekst hist. Jerzy Piotr Majchrzak. Ząbki-Sulechów 2004 Apostolicum ss. 99 , il.

\section{Papieski Wydział Teologiczny we Wroclawiu}

357. MIĘDZY królewskim Krakowem a piastowskim Wrocławiem. Doktorat Honoris Causa Papieskiego Wydziału Teologicznego we Wrocławiu Księdza Profesora Jana Kowalskiego. Słowo od red. Tadeusz Reroń i Andrzej Szafulski. Wrocław 2002 Papieski Wydz. Teol. ss. 204, tabl. 6. 
Z treści: Młotek Antoni: Doktoraty „honoris causa” na Wydziale Teologii Katolickiej w XIX wieku s. 91-105; Reroń T.: Doktoraty „honoris causa” Wydziału Teologii Katolickiej w latach 1900-1945 s. 107-123; Szafulski A.: Doktoraty „honoris causa” na Papieskim Wydziale Teologicznym we Wroclawiu s. 125-138.

\section{Politechnika Śląska}

358. STULECIE tradycji Instytutu Techniki Cieplnej (1904-2004). Zebrał i oprac. Józef Szymczyk; współpr. Andrzej Ziębik. Gliwice 2004 Politech. Śląska w Gliwicach ss. 262, il.

Z treści: Lwów - Genus Loci. Nieformalna stolica Polski w latach 1860-1914 s. 8-17; Historia Politechniki Lwowskiej (1844-1946) s. 18-53; Lwowskie tradycje termodynamiki i energetyki cieplnej (1904-1946) s. 54-88; Krótki opis prawie 60 lat historii Politechniki Śląskiej s. 89-104; Śląskie tradycje Instytutu Techniki Cieplnej s. 105-120; 33 lata historii Instytutu Techniki Cieplnej Politechniki Śląskiej. Kalendarium s. 121-217; Sylwetki dyrektorów Instytutu Techniki Cieplnej: Prof. zw. dr inż. Jan Szargut s. 218-224; Prof. zw. dr hab. inż. Andrzej Ziębik s. 225-229; Dane o działalności naukowej i wydawniczej s. 230-250.

\section{Politechnika Wroclawska}

359. BANYŚ Kazimierz: Historia Wydziału Hutniczego Politechniki Wroclawskiej. Wrocław 2004 Oficyna Wydawnicza Politech. Wrocławskiej ss. 78, nlb. 2, il.

360. SZYMANKIEWICZ Felicjan: Przyczynek do historii Wydziału Mechanizacji Rolnictwa Politechniki Wrocławskiej. Wrocław 2004 Oficyna Wydawnicza Politech. Wrocławskiej ss. 79, nlb. 2, il.

\section{Szkola Glówna Gospodarstwa Wiejskiego}

361. [PIĘĆDZIESIĄT] 50 lat Wydziału Ekonomiczno-Rolniczego 1953-2003. Mater. oprac. Katarzyna Bogucka [i in.]. Warszawa 2003 Wydaw. SGGW ss. 423, nlb. 1, tabl. 4. Szkoła Gł. Gospodarstwa Wiejskiego w Warszawie.

Z treści: Stępka Stanisław: Geneza Wydziału s. 11-22; Struktura organizacyjna Wydziału s. 23-35; Stępka S.: Badania naukowe s. 37-48; Stępka S.: Kształcenie kadr naukowych s. 49-77; Walkiewicz Wiesław: Wspólpraca naukowa $z$ ośrodkami zagranicznymi s. 79-85; Bogacka K.: Studencki ruch naukowy s. 97-108; Pracownicy Wydziału s. 109-222; Farkowski Czeslaw: Wspomnienie wychowanka o Profesorze Stefanie Ignarze s. 223-226; Wojtaszek Zygmunt: Ryszard Manteuffel s. 227-238; Absolwenci Wydziału s. 251-422.

\section{Szkoła Podchorążych Marynarki Wojennej w Toruniu}

362. NAWROT Dariusz: Losy Szkoły Podchorążych Marynarki Wojennej w latach II wojny światowej. Kom. Inst. Batt. R. 36/37: 2002 z. 45 s. 22-40.

\section{Uniwersytet im. Adama Mickiewicza}

363. AMBROZIK Wiesław: Przemiany i dokonania poznańskiej pedagogiki. Rocz. Pedag. T. 27: 2004 s. $343-356$.

Z okazji 10-lecia istnienia Wydz. Studiów Edukacyjnych UAM. 
364. CZAJKOWSKA Agnieszka: Sprawozdanie z działalności Koła Naukowego Historii Kultury i Edukacji UAM. Biul. Hist. Wych. 2004 nr 1/2 s.141.

365. KOSMAN Marceli: Ile lat liczy „Alma Mater Posnaniensis?”. Odrodzenie i Reformacja w Polsce. T. 48: 2004 s. 221-225.

366. W HOŁDZIE naszym Antenatom. 85 lat Uniwersytetu im. Adama Mickiewicza. Pod red. Jerzego Laskowskiego i Grzegorza Lukomskiego. Poznań 2004 Wydaw. Nauk. UAM ss. 133, nlb. 1, il., r,s., sum., Zsfg. UAM. (Dzieje UAM. Nr 15).

Z treści: Łukomski G.: Od Lubranscianum do Uniwersytetu Poznańskiego s. 11-59; Sylwetki założycieli Uniwersytetu: Marciniak Anna: Heliodor Święcicki (1854-1923) s. 63-80; Szczesiak Marta: Michał Sobeski (1877-1939) s. 81-92; Marciniak R.: Ks. Stanisław Kozierowski (1874-1949) s. 93-108; Szczesiak M.: Józef Kostrzewski (1885-1969) s. 109-124.

367. ZARYS dziejów Wydziału Prawa Uniwersytetu w Poznaniu 1919-2004. Red. Krzysztof Krasowski. Poznań 2004 Wydaw. Poznańskie ss. 307, il.

Treść: Krasowski K.: Wydział Prawno-Ekonomiczny Uniwersytetu Poznańskiego w latach 1919-1939 s. 11-81; Sikorska-Dzięgielewska Krystyna: Pracownicy Wydziału w okresie II wojny światowej s. 83-95; Sikorska-Dziegielewska K.: Wydział w latach 1945-1956 s. 97-144; Stanulewicz Maksymilian: Wydział Prawa w latach 1956-1969 s. 145-203; Krzymkowski Marek: Wydział Prawa i Administracji w latach 1969-1990 s. 205-245; Materniak-Pawłowska Małgorzata: Wydział Prawa i Administracji w latach 1990-2004 s. 247-289.

Rec.: Schramm Tomasz, Czasop. Prawno-Hist. T. 56: 2004 z. 2 s. 430-433.

\section{Uniwersytet Jagielloński}

368. GRYGLEWSKI Ryszard W.: Trudne lata Muzeum Wydziału Lekarskiego UJ w okresie międzywojennym. Kwart. Hist. Nauki i Techn. R. 49: 2004 nr 3/4 s. 197-207.

369. KOWALIK Beata: Nowotarżanie - studenci Uniwersytetu Jagiellońskiego w latach 1868/69 - 1938/39. Almanach Nowotarski. Nr 8: 2004 s. 35-51.

370. KULCZYKOWSKI Mariusz: Żydzi - studenci Uniwersytetu Jagiellońskiego w Drugiej Rzeczypospolitej (1918-1939). Kraków 2004 PAU ss. 734, tabl. 14, sum. PAU. (Prace Komisji Historii i Kultury Żydów. [T.] 5).

Rec.: Tomaszewski Jerzy, Kwart. Hist. Żydów. [R. 4]: 2004 nr 4 s. 623-625.

371. METRYKA Uniwersytetu Krakowskiego z lat 1400-1508. Biblioteka Jagiellońska rkp. 258. Wyd. Antoni Gąsiorowski, Tomasz Jurek, Izabela Skierska; przy współpr. Ryszarda Grzesika. Kraków 2004 Tow. Nauk. „Societas Vistulana” 8řr.

T. 1: Tekst ss. LXII, 650 , il. + CD; T. 2: Indeksy ss. 767 , nlb. 1.

372. NASZ ślad. Wspomnienia absolwentów Wydziału Lekarskiego Uniwersytetu Jagiellońskiego (rocznik 1945-1950). Kraków 2004 Wydaw. Medyczne ss. 228, il. Rec.: Gaertner Henryk, Arch. Hist. i Filoz. Med. T. 67: 2004 z. 2/4 s. 216-217.

373. NOWAK Lucyna: Drogi recepcji pism Arystotelesa na Uniwersytecie Krakowskim. [W:] Kolory i struktury średniowiecza. Pod red. Wojciecha Fałkowskiego. Warszawa 2004 s. 57-67.

374. POLONIAE merenti. Ksiega pamiątkowa jubileuszu sześćsetlecia odnowienia Uniwersytetu Jagiellońskiego 1400-2000. Pod red. Stanisława Szczura. Kraków 2003 Ośr. Informacji i Promocji UJ ss. 566, nlb. 2, il.

Z treści: Ziejka Franciszek: Poloniae Merenti. (Przedmowa) s. 5-8; Szczur S.: Wstęp s. 9-11; Cz. 1: Władze Uniwersytetu Jagiellońskiego $w$ dobie jubileuszu s. 14-50; Cz. 2: Organizacja jubileuszu s. 52-66; 
Cz. 3: Ogólnouniwersyteckie uroczystości jubileuszowe s. 68-273; Cz. IV: Wokół jubileuszu odnowienia uniwersytetu s. 276-563.

375. POLSKI październik 1956 roku na Uniwersytecie Jagiellońskim. Materiały sympozjum zorganizowanego pod patronatem J.M. Rektora prof. Franciszka Ziejki przez Uniwersytet Jagielloński, Instytut Pamięci Narodowej i Konsulat Generalny Republiki Wegierskiej w dniu 10 listopada 2001 roku w Krakowie. Red. Rudolf Klimek. Kraków 2004 Universitas ss. 244, tabl. 2.

Treść: Ziejka F.: Przedmowa s. 7-12; Klimek R.: Wstęp s. 13-16; Huczkowski Jerzy: Studencki Komitet Rewolucyjny w Krakowie i jego losy s. 17-27; Michalewski Jerzy: Mój Październik 1956 s. 29-44; Kozłowski Jan: Studencki Komitet Rewolucyjny - Kraków 1956 (fakty i refleksje) s. 45-58; Bratkowski Andrzej: Studencki Komitet Pomocy Walczącym Węgrom (Kraków 1956) s. 59-70; Tischler János: Polska i Polacy a rewolucja wegierska 1956 roku s. 71-100; Terlecki Ryszard: Polska jesień 1956 roku - czego jeszcze nie wiemy? s. 101-108; Dąbrowski Maciej: Wspomnienia i refleksje z 1956 roku s. 109-114; Podolak Sławomir: Mój osobisty Październik '56 s. 115-133; Sikora Zbigniew: O roku ów (1956), kto ciebie widział w naszym mieście s. 135-179; Stępień Marian: Zmiany w uniwersyteckiej organizacji partyjnej w 1956 roku s. 181-187; Wielgosz Julian: Związek Młodzieży Robotniczej w Krakowie (grudzień 1956) s. 189-206; Klimek R.: Uwarunkowania i osiagnięcia polskiego Października '56 w odzyskaniu wolności s. 207-219; Aneks [Dokumenty Rewolucyjnego Zwiazzu Młodzieży i Studenckiego Komitetu Rewolucyjnego] s. 229-244.

376. SŁAWIŃSKI Stanisław, Hiżycka Joanna: Budynki krakowskiego Collegium Maius przed połową XV wieku. Zesz. Nauk. UJ. [Nr] 1268: Opuscula Musealia. Z. 13: 2004 s. 139-150, sum.

377. SONDEL Janusz: Biskupi jako kanclerze i opiekunowie Uniwersytetu Krakowskiego. [W:] "Lex tua in corde meo". Studia i materiały dedykowane Jego Magnificencji bp. Tadeuszowi Pieronkowi z okazji 40-lecia pracy naukowej. Kraków 2004 s. 473-494.

378. SZCZUR Stanisław: Suplika w sprawie Wydziału Teologicznego Uniwersytetu Krakowskiego. [W:] „Lex tua in corde meo”. Studia i materiały dedykowane Jego Magnificencji bp. Tadeuszowi Pieronkowi z okazji 40-lecia pracy naukowej. Kraków 2004 s. 495-502.

379. WALTOŚ Stanisław: Na tropach doktora Fausta i inne szkice. Warszawa 2004 Wydawnictwa Szkolne i Pedagog. ss. 242, nlb. 1, il.

Uniwersytet Jagielloński w kontekście kultury europejskiej, XIV-XX w.

380. ŻUKOWSKI Przemysław Marcin: Źródła w dziejów Uniwersytetu Jagiellońskiego. Sprawa prof. Maurycego Straszewskiego z 1905 roku. Archiwista Pol. R. 9: 2004 nr 4 s. 31-36, sum.

\section{Uniwersytet Lwowski}

381. LAVREC'KIJ Roman: Organizacja studiów historycznych na Uniwersytecie Lwowskim w latach 1918-1939. [W:] Wielokulturowe środowisko historyczne Lwowa w XIX i XX w. T. 2. Pod red. Jerzego Maternickiego, Leonida Zaszkilniaka. Rzeszów 2004 s. 297-308.

382. LUNDGREEN Peter: Uniwersytet Lwowski i jego historycy (1784-1914); perspektywy porównawcze niemieckiego i austriackiego rozwoju. [W:] Wielokulturowe środowisko historyczne Lwowa w XIX i XX w. T. 1. Pod red. Jerzego Maternickiego. Rzeszów 2004 s. 101-125.

\section{Uniwersytet Łódzki}

383. CERAN Waldemar: Bizantynistyka na Uniwersytecie Lódzkim w latach 1999-2003. Prz. Hist. T. 95: 2004 z. 1 s. 109-118. 
384. GREGOR Bogdan, Mikołajczyk Zofia: 10 lat Wydziału Zarządzania Uniwersytetu Lódzkiego. Lódź 2004 Wydaw. Uniw. Lódzkiego ss. 195.

385. SZYMCZAK Jan: Pięćdziesiąt lat Wydziału Filozoficzno-Historycznego Uniwersytetu Lódzkiego. Rocz. Lódz. T. 50: 2003 s. 65-70.

Lata 1952-2002.

\section{Uniwersytet Marii Curie-Sklodowskiej}

386. WRÓBEL-LIPOWA Krystyna: Czterdzieści lat dydaktyki historii w Uniwersytecie Marii Curie-Skłodowskiej. Res Historica. Z. 18: 2004 s. 9-11.

\section{Uniwersytet Mikolaja Kopernika}

387. PRUSINKIEWICZ Zbigniew: Dzieje Zakładu Gleboznawstwa od początku istnienia do roku 1993 we wspomnieniach jego wieloletniego kierownika. Toruń 2003 TN ss. 35, nlb. 1, tabl. 8 . Tow. Nauk. w Toruniu, UMK. Inst. Ekologii i Ochrony Środowiska.

388. WRÓBLEWSKI Witold: Katedra Filologii Klasycznej Uniwersytetu Mikołaja Kopernika w latach 1945-1995. [W:] Studia thorunensio-classica. Tradycje antyczne w Polsce Północnej. Warszawa 2002 s. 19-23.

\section{Uniwersytet Opolski}

389. NICIEJA Stanisław Sławomir: Alma Mater Opoliensis. Ludzie, fakty, wydarzenia. Księga jubileuszowa w 50. rocznicę powstania Uniwersytetu Opolskiego. Opole 2004 Uniw. Opolski ss. 504, il.

\section{Uniwersytet Szczeciński}

390. KSIEGA jubileuszowa z okazji 15-lecia Wydziału Prawa i Administracji Uniwersytetu Szczecińskiego. Pod red. Zbigniewa Ofiarskiego. Szczecin 2004 Wydaw. Nauk. US ss. 659, il. Uniw. Szczeciński. (Rozprawy i Studia. T. 504).

Z treści: Bogucki Olgierd: Droga do Wydziału Prawa i Administracji Uniwersytetu Szczecińskiego s. 11-14; Dziekani Wydziahu Prawa i Administracji Uniwersytetu Szczecińskiego s. 15-32; Doktoraty na Wydziale Prawa i Administracji Uniwersytetu Szczecińskiego s. 33-42; Struktura organizacyjna Wydziału Prawa i Administracji Uniwersytetu Szczecińskiego s. 43-52.

391. UNIWERSYTET Szczeciński od inicjatywy do inauguracji. Materiały i dokumenty. Wybór i oprac. Kazimierz Jaskot. Wyd. 2 popr. i uzup. Szczecin 2004 Tow. Przyj. Szczecina ss. 638, nlb. 2, tabl. 6, mapy.

Dokumenty z $1.1947-1985$.

\section{Uniwersytet Warszawski}

392. BIAŁOŃ Adam: Pół wieku Katedry Filologii Ukraińskiej Uniwersytetu Warszawskiego. Biul. Ukr. [Nr] 9: 2003 [druk.:] 2004 s. 179-183. 
393. KOLENDO Jerzy: Zbiory zabytków pradziejowych na Uniwersytecie Warszawskim. Swiatowit. T. 4: 2002 fasc. B s. 87-100, sum.

XIX-XX w.

394. UNIWERSYTET Warszawski 1870-1915. Materiały bibliograficzne. Cz. 2. Oprac. Jadwiga Krajewska, Anna Bednarz. Warszawa 2004 Wydawnictwa UW ss. 648, nlb. 1. Bibl. Uniwersytecka w Warszawie.

Toż. Cz. 3: Indeksy. Oprac. J. Krajewska, A. Bednarz. Warszawa 2004 ss. 136, nlb. 1.

Cz. 1. 2002.

\section{Uniwersytet Wileński}

395. GRIMALAUSKAITË Dalia: Gabinet numizmatyczny Cesarskiego Uniwersytetu Wileńskiego (1803-1832). Wiad. Num. R. 48: 2004 z. 2 s. 129-152, sum.

396. KAMIŃSKA Janina: Universitas Vilnensis. Akademia Wileńska i Szkoła Główna Wielkiego Księstwa Litewskiego 1773-1792. Pułtusk-Warszawa 2004 WSH; Aspra-Jr ss. 229, nlb. 3, tabl. 8, sum., streszcz. lit. Uniw. Warszawski. Wydz. Pedagog.; Wyższa Szkoła Humanist. im. Aleksandra Gieysztora.

397. NICZYPORUK Piotr: Nauczanie prawa rzymskiego w Akademii Wileńskiej. [W:] Wielokulturowość polskiego pogranicza. Ludzie, idee, prawo. Materiały ze Zjazdu Katedr Historycznoprawnych, Augustów 15-18 września 2002 roku. Pod red. Adama Lityńskiego i Piotra Fiedorczyka. Białystok 2003 s. 145-162.

398. NICZYPORUK P.: Promocje doktorskie obojga praw w Akademii Wileńskiej. Misc. Hist.-Iur. T. 2: 2004 s. 17-31, sum.

W l. 1647-1779.

399. ZIENKIEWICZ Tadeusz: Białorusini na Uniwersytecie Stefana Batorego w Wilnie (rekonesans). Acta Polono-Ruthenica. [T.] 9: 2004 s. 173-183, rez., sum.

\section{Uniwersytet Wroclawski}

400. BIALY Franciszek: Uniwersytet Wrocławski w strukturach narodowosocjalistycznej Rzeszy Niemieckiej. Zblizenia. Polska-Niemcy. [R. 12]: 2002 nr 3 s. 30-39, Zsfg.

401. HISTORIA nauk geologicznych na Uniwersytecie Wrocławskim 1811-2003. Pod red. Andrzeja Grodzickiego. Wrocław 2003 Wydaw. Uniw. Wrocławskiego ss. 317, nlb. 2, il., sum., Zsfg. (Acta Universitatis Wratislaviensis. No 2550).

Z treści: Mierzejewski Michał P., Sachanbiński Michał, Wierzbicki Zbigniew: Zarys historii nauk mineralogicznych i geologicznych na Uniwersytecie Wrocławskim w latach 1811-1945 s. 13-43; Skoczylas Janusz: Polacy oraz polscy studenci geologii i mineralogii we Wrocławiu i na Uniwersytecie Wrocławskim do 1945 roku s. 44-50; Nauki geologiczne na Uniwersytecie Wroclawskim w latach 1945-2003 s. 55-305.

402. SCHMIED-KOWARZIK Wolfdietrich: Der grosse Skandal an der Universität Breslau um die Nachfolge des Philosophen Richard Hönigswald im Jahre 1930. Zblizenia. Polska-Niemcy. [R. 10]: $2000 \mathrm{nr} 2$ s. 57-68, streszcz. 
403. SEMP Natasza: Wrocławska przygoda z socjologią. Katedra Socjologii i Studia Socjologiczne na Uniwersytecie Wroclawskim w latach 1946-1953. Nauki Hum. [Nr] 8: 2003 [dr.:] 2004 s. $368-387$, sum.

404. URNIA Agnieszka J.: Nauczanie języka czeskiego na Uniwersytecie Wrocławskim. [W:] Wrocław w Czechach - Czesi we Wrocławiu. Literatura, język, kultura. Red. nauk. Zofia TarajłoLipowska i Jaroslaw Malicki. Wroclaw 2003 s. 156-160.

\section{Wojskowa Akademia Techniczna}

405. WOJSKOWE akademie w Polsce. Praca zespołowa. Pod red. Michała Hebdy. Warszawa 2003 Pol-Press ss. 647, nlb. 5, il.

Wydana z okazji Zjazdu Absolwentów WAT pierwszej promocji 1953 r.

\section{Wyższa Szkoła Policji}

406. [PIĘĆDZIESIĘCIOLECIE] 50-lecie oficerskiego szkolnictwa policyjnego w Szczytnie (1954-2004). Red. nauk. Mieczysław Goettel, Andrzej Misiuk; przewodn. zespołu red. Aleksander Babiński. Szczytno 2004 Wydaw. Wyższej Szkoły Policji ss. 208, il.

Treść: Majer Piotr: Od Ośrodka Szkolenia Oficerów Milicji Obywatelskiej do Wydziału Porządku Publicznego Akademii Spraw Wewnętrznych. Podstawowe przeobrażenia milicyjnej placówki dydaktycznej w Szczytnie w latach 1954-1990 s. 9-30; Siemak Zbigniew: Wyższa Szkoła Policji w Szczytnie (10 X 1990-) s. 31-57; Wiszowaty Edward: Duszpasterstwo Wyższej Szkoły Policji w Szczytnie s. 58-59; [Zdjęcia] s. 60-154; Kamassa Dariusz: Kalendarium s. 155-190; Rykowska Jadwiga, Skarżyński Bogdan: Oficerskie szkolnictwo policyjne w Szczytnie (wybór źródel i opracowań) s. 191-208.

\section{Wyższe Seminarium Duchowne w Sandomierzu}

407. STANASZEK Bogdan: Represje władz komunistycznych wobec Wyższego Seminarium Duchownego w Sandomierzu w czasach Wladyslawa Gomułki. Zesz. Sand. R. 11: 2004 nr 18 s. $37-43$.

\section{Wyższe Śląskie Seminarium Duchowne}

408. WYŻSZE Śląskie Seminarium Duchowne 1924-2004. Red. Józef Kupny. Katowice 2004 Księg. Św. Jacka ss. 638 , nlb. 2, il.

Treść: Kupny J.: Wstęp s. 9-12; Kłakus Michał: Geneza i rozwój Śląskiego Seminarium Duchownego w Krakowie (1924-1945) s. 15-50; Zyzak Marek: Dzieje Wyższego Śląskiego Seminarium Duchownego po II wojnie światowej s. 51-78; Myszor Wincenty: Wyższe Śląskie Seminarium Duchowne i Wydział Teologiczny Uniwersytetu Śląskiego w Katowicach s. 79-86; Olszar Henryk: Rektorzy Wyższego Śląskiego Seminarium Duchownego w latach 1924-2004 s. 87-138; Palion Adam: „Seminarium to też budynek”. Zarys historyczny powstania budynków Wyższego Śląskiego Seminarium Duchownego w Krakowie i Katowicach s. 139-174; Czakański Tadeusz: Formacja intelektualna i działalność naukowa w Wyższym Śląskim Seminarium Duchownym w latach 1924-2001 s. 175-214; Marek Andrzej: Formacja duchowa w Wyższym Śląskim Seminarium Duchownym s. 215-260; Czakański T.: Początki i rozwój formacji pastoralnej alumnów diecezji katowickiej 
s. 261-282; Czakański T.: Historia Biblioteki Wyższego Śląskiego Seminarium Duchownego s. 283-292; Czakański T.: „Libri martyres”. Gdy książka byla wrogiem s. 293-298; Klakus Michał: Powstanie i rozwój czasopism kleryckich „Naszej Myśli” (1952-1988) i „Initium” (1968-2001) s. 299-307; Luczak Marek, Larysz Piotr: Ślasscy klerycy w służbie wojskowej s. 308-317; Zaborowska Kanizja Leokadia: Shuźba sióstr elżbietanek w seminarium s. 318-335; Zaborowska K. L.: Praca świeckich w seminarium s. 336-344; Wspomnienia biskupów i kapłanów s. 345-504; Wychowawcy seminaryjni s. 505-516; Biskupi - absolwenci i wychowawcy Wyższego Śląskiego Seminarium Duchownego s. 517-524; Księża absolwenci Wyższego Śląskiego Seminarium Duchownego 1923-2004 s. 525-584.

\section{BIOGRAFIE}

\section{Zbiory życiorysów}

409. BIOGRAFIE nauczycieli zasłużonych dla oświaty i środowiska regionu puławskiego. T. 2. Oprac. red. Stanisław Jednacz, Danuta Kaliszczuk. Puławy 2004 Tow. Przyj. Muzeum Oświatowego ss. 160 , il.

T. 1. 2002.

410. GDAŃSKIE rodowody pedagogiczne. Geneza, kontynuacje, inspiracje, przemieszczenia znaczeń wychowawczych. Pod red. Ewy Rodziewicz, Krystyny Rzedzickiej, Ewy Zalewskiej. Gdańsk 2004 Wydaw. Uniw. Gdańskiego ss. 295, nlb. 1.

Materiały konferencji naukowej, Gdańsk 24-25 VI 2002 r.

Profesor Kazimierz Sośnicki - pedagog, dydaktyk, filozof (11.01.1883 Lwów - 11.06.1976 Gdańsk); Profesor Ludwik Bandura - dydaktyk, pedagog (03.04.1904 Berlin - 20.08.1984 Gdańsk); Profesor Romana Miller - pedagog, teoretyk wychowania (12.12.1906 Warszawa - 12.07.1983 Gdańsk); Rodziewicz E.: Korzenie, pamięć i współczesne przejęcia znaczeń powojennej pedagogiki gdańskiej. (Zamiast wstępu) s. 19-49; Wapiński Roman: Ze wspomnień o twórcach pedagogiki w Gdańsku s. 81-84; Wiatrowski Zygmunt: Autorytety i mistrzowie w naukach pedagogicznych w Polsce w drugiej połowie XX wieku s. 85-93; Szabała Henryk: Wspomnienie o Profesorze Ludwiku Bandurze s. 94-103; Góra Henryk: Profesor Ludwik Bandura - osobowość moralna s. 108-110; Grzybowski Romuald: Początki oraz niektóre aspekty rozwoju nauk pedagogicznych w Gdańsku po 1945 roku s. 111-122; Nalaskowski Stanisław: Epizod z zawodowej biografii Kazimierza Sośnickiego s. 123-125; Materne Jerzy: Pedagogika Kazimierza Sośnickiego i Romany Miller na tle zachodnioniemieckiej nauki o wychowaniu. (Zarys zagadnienia) s. 137-143; Hejnicka-Bezwińska Teresa: Pedagodzy wobec relacji pedagogia-pedagogika. (Dyrektywy sformułowane przez Kazimierza Sośnickiego) s. 144-156; Balukiewicz Małgorzata: Koncepcje pedagogiczne Kazimierza Sośnickiego prezentowane na łamach „Muzeum” - organu Lwowskiego Towarzystwa Nauczycieli Szkół Wyższych (1918-1939) s. 172-181; Puchowska Małgorzata: Romany Miller rozważania o edukacji teatralnej s. 201-205; Papież Jan: Wyrównywanie startu szkolnego w mieście i na wsi. (Raport z badań zbiorowych Romany Miller - interpretacje po 25 latach) s. 206-212; Góra Mariola: Muzeum Pedagogiczne Profesora Kazimierza Sośnickiego w Gdańsku s. 291-292.

411. GRĘDZIK Agnieszka: Polscy nauczyciele z ziem północno-wschodnich II Rzeczypospolitej - ofiary zbrodni sowieckich w latach 1939-1941, deportowani, więzieni, zamordowani, rozstrzelani. Prz. Hist.-Ośw. R. 47: 2004 nr 3/4 s. 169-209.

412. KOWALSKI Tadeusz: Nauczyciele ziemi pułtuskiej w latach wojny i okupacji niemieckiej (1939-1945). Cz. 2. Rocz. Maz. T. 16: 2004 s. 91-107.

Cz. 1. Tamże. T. 15: 2003.

413. LUDZIE Akademii Medycznej w Gdańsku. Praca zbiorowa. [T. 2]. Pod red. Zbigniewa Machalińskiego. Gdańsk 2004 AM ss. 193, il. Akad. Medyczna w Gdańsku. (Prace Zakładu Historii i Filozofii Nauk Medycznych. Ser. Biograficzna. T. 2).

T. 1. 2003. 
414. POCZET rektorów Alma Matris Posnaniensis. Red. nauk. Tomasz Schramm; współpr. Anna Marciniak. Poznań 2004 Wydaw. Nauk. UAM ss. 290, nlb. 1, tabl. 8. UAM w Poznaniu. (Dzieje UAM. Nr 16).

415. RZECZ o... przełożonych Wyższego Śląskiego Seminarium Duchownego w Katowicach. Red. Adam Palion. Katowice 2003 Adam Palion ss. 151, il.

416. SLOWNIK biograficzny Związku Nauczycielstwa Polskiego na Lubelszczyźnie. Pod red. Jerzego Doroszewskiego. Lublin 2004 ZNP. ZOL ss. 354. Zw. Nauczycielstwa Pol. Zarząd Okręgu Lubelskiego.

417. SŁOWNIK katechetów polskich XX wieku. Praca zbiorowa. Pod red. Ryszarda Czekalskiego przy współpr. Zbigniewa Marka i Romana Murawskiego. Warszawa 2003 Wydaw. Salezjańskie ss. 296.

418. ZŁOTA księga Wydziału Lekarskiego. T. 2. Pod red. Jana Grochowskiego. Kraków 2004 Księg. Akademicka ss. 114, nlb. 1, il. UJ. (Złote Ksiegi Uniwersytetu Jagiellońskiego).

T. 1.2000.

419. ZLOTA księga. Suplement. Pod red. Wacława Waleckiego. Kraków 2004 Księg. Akademicka ss. 202, nlb. 2, il. (Złote Księgi Uniwersytetu Jagiellońskiego).

\section{Poszczególne osoby}

\section{Bednarczyk Piotr}

420. KADDZIOŁKA Władysław: Pedagogiczna i duszpasterska działalność biskupa Piotra Bednarczyka [1914-2001]. Kraków 2004 Unum ss. 202, nlb. 6, tabl. 16. Papieska Akad. Teol. w Krakowie. Wydz. Teol.

\section{Bogdański Antoni}

421. DĘBIŃSKI Józef: O druhu ks. Antonim Bogdańskim [1891-1938] i harcerstwie na Kujawach wschodnich i ziemi dobrzyńskiej. Studia Wloclawskie. T. 7: 2004 s. 397-406.

\section{Borowska Sylwia}

422. PAŁGAN Iwona: Sylwia Borowska - zapomniana nauczycielka. Rocz. Nauk. Spol. T. 31: 2003 z. 2 s. 101-114, sum.

\section{Bronislaw Markiewicz, bl.}

423. KUSTRA Czesław: Bronisław Bonawentura Markiewicz (1842-1912) - prekursor pedagogiki opiekuńczej w Polsce. Kwart. Pedag. R. 47: 2002 nr 3/4 [druk.:] 2003 s. 87-101, sum. 


\section{Golawski Michal}

424. ROMANIUK Zbigniew, Trynkowski Jan: Życie dla polskiej oświaty. Michał Goławski (1904-1974). Białystok 2004 Książnica Podlaska im. Łukasza Górnickiego ss. 110, nlb. 1, tabl. 14.

\section{Jędrzejewicz Janusz}

425. KOŹMIAN Danuta: Janusz Jędrzejewicz - polityk i pedagog (1885-1951). Szczecin 2004 Wydaw. Nauk. US ss. 171, il., Zsfg. Uniw. Szczeciński. (Rozprawy i Studia. T. 494).

\section{Kalenkiewicz Irena z Erdmanów}

426. GOŚCIEJ Józef: Irena Kalenkiewicz z Erdmanów (1908-1994). Szkic do portretu zashużonej polonistki szkół rolniczych. Prz. Hist.-Ośw. R. 47: 2004 nr 1/2 s. 69-73.

\section{Kalas Józef}

427. DERENDA Jerzy: Józef Kałas (1873-1939) - pedagog i społecznik. Kronika Bydgoska. T. 25: 2003 [druk.:] 2004 s. 383-387.

\section{Kaniorowa Wanda}

428. DRELA Luiza: Wanda Kaniorowa - pedagog, twórca i kierownik zespołu artystycznego (1912-1980). Rocz. Nauk. Spol. T. 31: 2003 z. 2 s. 43-70, sum.

\section{Kaźmierczak Antoni}

429. WITKOWSKI Zdzisław: Antoni Kaźmierczak - nauczyciel, przyrodnik, regionalista (1921-1995). Pam. TMZK. T. 11: 2001/2004 [druk.:] 2004 s. 158-168.

\section{Komar Jadwiga}

430. SADOWSKI Wojciech: Jadwiga Komar (1890-1962). Nadwarciański Rocz. Hist.-Archiw Nr 11: 2004 s. 283-285.

\section{Krotkiewski Stanisław}

431. WIECZOREK Grzegorz: Materiały do biogramu działacza harcerskiego Stanisława Krotkiewskiego (1901-2003). [W:] Historia i archiwistyka. Studia z dziejów Polski, Polonii i archiwi- 
styki. Księga dedykowana księdzu doktorowi Romanowi Nirowi. Pod red. Janusza Farysia, Dariusza A[leksandra] Rymara i Marka Szczebińskiego. Gorzów Wielkopolski 2004 s. 495-500.

\section{Kulpa Jan}

432. PROFESOR Jan Kulpa [1908-1983] - wybitny pedagog polski. (Materiały pokonferencyjne). Pod red. Elżbiety Bryckiej, Marii Chymuk. Kraków-Radom 2004 Akad. Pedagog. im. KEN. Inst. Nauk o Wychowaniu; Inst. Technologii Ekspoloatacji ss. 104, il.

Z treści: Żaliński Henryk: Otwarcie sesji poświęconej prof. Janowi Kulpie s. 9-11; Kuźma Józef: Profesor Jan Kulpa - sylwetka uczonego i jego osiagnięcia naukowe s. 12-16; Aleksander Tadeusz: Profesor Jan Kulpa jako andragog s. 20-27; Jarowiecki Jerzy: Jan Kulpa i jego współpraca $z$ ludową prasą konspiracyjną podczas hitlerowskiej okupacji s. 28-40; Chymuk M.: Człowiek wielkiego serca s. 45-53; Czekaj Ewa: Nauczyciel nauczycieli patronem Krakowskiego Młodzieżowego Towarzystwa Przyjaciół Nauk i Sztuk s. 54-70; Faron Bolesław: Wspomnienie o Profesorze Janie Kulpie s. 73-75; Banach Czesław: Pamięcią jestem z Nim wspomnienie o Profesorze Janie Kulpie s. 76-79; Rozmowa z prof. dr. hab. Janem Kulpa. [Oprac.] Stanisław Szwabowski s. 80-82; Aneks. Zdjęcia z sesji - Materialy archiwaine (kopie) s. 85-104.

\section{Lisowski Józef}

433. WASIAK Marek: Józef Lisowski (1921-1992). Prz. Hist.-Ośw. R. 47: 2004 nr 3/4 s. 245-249.

\section{Majorek Czeslaw}

434. RUTA Zygmunt: Profesor Czesław Majorek (1938-2002). Lub. Rocz. Pedag. T. 24: 2004 s. $345-348$.

\section{Malkowski Andrzej}

435. GŁOWACKA-SOBIECH Edyta: Andrzej Małkowski (1888-1919) - twórca i pionier polskiego skautingu. Prz. Hist.-Ośw. R. 46: 2003 nr 3/4 s. 93-110.

\section{Młodyński Józef Kazimierz}

436. KOWALSKI Tadeusz: Józef Kazimierz Młodyński - pedagog - polonista - współtwórca kultury Mazowsza (1930-2003). Rocz. Maz. T. 16: 2004 s. 193-196.

\section{Mrozowska Kamilla}

437. MEISSNER Andrzej: Profesor Kamilla Mrozowska (1917-2002). Prz. Hist.-Ośw. R. 47: $2004 \mathrm{nr} 3 / 4$ s. 237-243.

438. SZYBIAK Irena: Kamilla Mrozowska (1917-2002). Kwart. Pedag. R. 47: 2002 nr 1 s. 163-165. 


\section{Napiórkowska Alicja}

439. WASIAK Marek: Alicja Napiórkowska (1894-1982). Prz. Hist.-Ośw. R. 46: 2003 nr 3/4 s. $111-115$.

\section{Nowacki Tadeusz W.}

440. WIATROWSKI Zygmunt: 90 lat życia i 66 lat pracy naukowo-dydaktycznej profesora Tadeusza W. Nowackiego. Prz. Hist.-Ośw. R. 47: 2004 nr 1/2 s. 59-64.

\section{Orlowiczówna Jadwiga}

441. Wojtyczka Janusz: Jadwiga Orłowiczówna (1905-1945). Rocz. Kom. Nauk Pedag. T. 57: 2004 s. 23-31, Zsfg.

\section{Rauch Elsa}

442. GUMOLA Mieczysław: Nauczycielka z Hamburga [Elsa Rauch, 1888 - ok. 1942]. Pamięć zapisana w skale. Kronika M. Lodzi. 2004 nr 1 s. 22-25.

\section{Sośnicki Kazimierz}

443. KAZIMIERZ Sośnicki [1883-1976] - twórca dydaktyki polskiej. Praca zbiorowa. Pod red. Renaty Góralskiej [i in.]. Toruń-Płock 2003 Novum ss. 347, nlb. 1, tabl. 3. UMK w Toruniu. Wydz. Humanistyczny, Szkoła Wyższa im. Pawła Włodkowica w Płocku.

Treść: Wołoszyn Stefan: Kazimierz Sośnicki (1883-1976) - pedagog, profesor UMK s. 15-18; Półturzycki Józef: Kazimierz Sośnicki - człowiek i dzielo s. 19-27; Gajdamowicz Halina: Ponadczasowy wymiar pedagogiki Kazimierza Sośnickiego s. 29-43; Wojdyło Witold: Droga Kazimierza Sośnickiego do katedry uniwersyteckiej s. 45-56; Nalaskowski Stanisław: Epizod z zawodowej biografii Kazimierza Sośnickiego s. 57-60; Jaworska Bolesława: Spuścizna Kazimierza Sośnickiego - w poszukiwaniu źródeł bibliograficznych s. 61-66; Jaworska B.: Bibliografia prac naukowych Kazimierza Sośnickiego s. 67-73; Jaworska B.: Bibliografia publikacji o osobie i twórczości Kazimierza Sośnickiego s. 75-77; Swirko-Pilipczuk Janina: „Ogólność” dydaktyki w ujęciu Kazimierza Sośnickiego - aktualność poglądów s. 81-87; Góra Henryk: Kazimierz Sośnicki jako twórca polskiej dydaktyki epistemologicznej s. 89-92; Góralska R.: Istota uczenia się w ujęciu Kazimierza Sośnickiego s. 93-99; Ciechanowska Dorota: Znaczenie wiedzy o procesie uczenia się w poglądach Kazimierza Sośnickiego s. 101-105; Bereźnicki Franciszek: Aktualność poglądu Kazimierza Sośnickiego odnośnie metod mauczania s. 107-110; Piotrowski Eugeniusz: Wkład Kazimierza Sośnickiego do rozwoju koncepcji nauczania strukturalnego s. 111-115; Groenwald Maria: „Tłumaczenie” zasad nauczania Kazimierza Sośnickiego s. 117-124; Klim-Klimaszewska Anna, Maciejewski Jan: Aktualność poglądów Kazimierza Sośnickiego na ocenę uczenia s. 125-132; Pieczywok Andrzej: Kształtowanie samodzielności uczniów w ujęciu Kazimierza Sośnickiego s. 133-145; Boczar Michal: Klasyczne, aktywistyczne, woluntarystyczne koncepcje kształcenia jako przedmiot badań wspólczesnej dydaktyki ogólnej z inspiracji Kazimierza Sośnickiego s. 147-159; Wesołowska Eugenia Anna: Refleksje Kazimierza Sośnickiego o podręcznikach szkolnych s. 161-165; Frącko- 
wiak Anna: Jak pisać dobre podręczniki? Aktualność wskazań Kazimierza Sośnickiego s. 167-177; Wesołowska E. A.: Wychowanie państwowe Kazimierza Sośnickiego s. 181-189; Rutkowiak Joanna: „Odpowiedzialność" w ujęciu Kazimierza Sośnickiego a perspektywa znaczeń tej kategorii pedagogiczno-społecznej s. 191-201; Żukowska Zofia: Kazimierz Sośnicki o samokształceniu pedagogicznym a kultura pedagogiczna nauczyciela s. 203-207; Magda Marzenna: Twórczość pedagoga wg poglądów Kazimierza Sośnickiego i jej przejawy u wspólczesnego nauczyciela s. 209-220; Andrukowicz Wiesław: Integralność stylów myślenia według Kazimierza Sośnickiego s. 221-231; Kwieciński Zbigniew: Uwagi dyskusyjne na Toruńskiej Konferencji Dydaktycznej nt. aktualności poglądów dydaktycznych Kazimierza Sośnickiego (11.12.2002) s. 239-241; Góra H.: Muzeum Pedagogiczne Profesora Kazimierza Sośnickiego w Białośliwiu s. 243-249; Góra Barbara: Archiwum i Centrum Dokumentacji i Twórczości Profesora Kazimierza Sośnickiego w Gdańsku s. 251-253; Derkowski Stanisław: Znaczenie nauczycielskiej działalności i naukowej pedagogicznej twórczości Profesora Kazimierz Sośnickiego s. 255--289; Górnikiewicz Jacek Kazimierz: Kazimierza Sośnickiego obecność w wirtualnym świecie Internetu (okolicznościowo-bez twarzy-bez głosu) s. 291-304; Frąckowiak A.: Sprawozdanie z XI Toruńskiej Konferencji Dydaktycznej „Aktualność poglądów dydaktycznych Kazimierza Sośnickiego w okresie przemian edukacyjnych na początku XXI wieku" s. 305-309; Półturzycki Józef: Toruńskie Konferencje Dydaktyczne w latach 1992-2002 s. 313-325; Półturzycki J.: O nowoczesny podręcznik dydaktyki ogólnej s. 327-347.

\section{Staronka Leszek Marek Maria}

444. PACZYŃSKA Irena: Leszek Marek Maria Staronka (1911-1945) - działacz oświatowy i społeczny. Studia Hist. R. 47: 2004 z. 3/4 s. 389-398.

\section{Szczepaniec Bronislawa}

445. TOTOŃ Anna: Wspomnienie o harcmistrzyni [Bronisławie Szczepaniec, zm. 1996]. Almanach Sądecki. R. 12: $2003 \mathrm{nr} 3$ s. 40-43.

\section{Tokarski Witold}

446. LEŚNIAK Jerzy: Witold Tokarski - „Ojciec” (1909-2003). Rocz. Sqdecki. T. 32: 2004 s. $495-497$.

\section{Tournelle Aleksandra}

447. WOŹNIAK Hieronim: Aleksandra Tournelle. Karta Groni. Nr 22: 2003 s. 232-234.

Kierowała Szkołą Powszechną Żeńską w Żywcu w l. 1897-1929.

\section{Weidel Stefan}

448. GRZEBIEŃ Ludwik: Stefan Weidel SJ [1905-1970]. Nauczyciel i wychowawca. Kraków 2004 Wyższa Szkoła Filoz.-Pedagog. „Ignatianum” ss. 47, nlb. 1, il. 


\section{Woloszyn Stefan}

449. Rotkiewicz Halina: Profesor Stefan Wołoszyn (1911-2004). Kwart. Pedag. R. 49: 2004 nr $1 / 2$ s. $7-10$.

\section{DZIEJE OŚWIATY POZASZKOLNEJ}

\section{Oświata dorosłych}

450. ALEKSANDER Tadeusz: Działalność niedzielnych uniwersytetów wiejskich na terenie Nowosądeckiego Związku Okręgowego TSL. Rocz. Sqdecki. T. 32: 2004 s. 56-69.

Od $1932 \mathrm{r}$.

451. BEDNARZAK-LIBERA Mirosława: Rola Towarzystwa Uniwersytetu Robotniczego w szerzeniu oświaty wśród robotników w II Rzeczypospolitej. Kierunki i formy działalności. [W:] Polska lewica w XX wieku. Historia, ludzie, idee. Pod red. Tadeusza Ślęzaka i Michała Śliwy. Kraków 2004 s. $119-136$.

452. SZYMAŃSKI Mirosław S.: „Ruch uniwersytetów ludowych” w Drugiej Rzeczypospolitej (1918-1939). Kwart. Pedag. R. 46: 2001 nr 3/4 [druk.:] 2002 s. 25-58, sum.

453. TOMASZEWSKA Liliana: Edukacja kobiet w Polsce. Płock 2004 Novum ss. 299, mapy. Szkoła Wyższa im. Pawła Włodkowica w Płocku. (Biblioteka Edukacji Dorosłych. T. 30).

$\mathrm{XX}$ w.

\section{Biblioteki}

454. KASZUBIK Stefania: Dziecko z książką. 55 lat pierwszej dziecięcej filii bydgoskiej Biblioteki Publicznej. Kronika Bydgoska. T. 25: 2003 [druk.:] 2004 s. 415-421.

455. KRAMARZ Henryka: Urządzenie i organizacja Biblioteki Zakładu Naukowo-Wychowawczego oo. Jezuitów w Bąkowicach k. Chyrowa (1886-1939). [W:] Librorum amatori. Księga pamiątkowa ofiarowana ks. Czesławowi Michalunio SJ na 50-lecie ofiamej pracy w Bibliotece Filozoficznej Towarzystwa Jezusowego w Krakowie. Red. Andrzej Paweł Bieś. Kraków 2004 s. 179-192.

456. POMES Kinga: Biblioteka II Gimnazjum w Rzeszowie w latach 1904-1939. Pr. Hist.-Archiw. T. 14: 2004 s. 167-174.

457. SZOCKI Józef: Biblioteki szkolne w procesie dydaktyczno-wychowawczym w dwudziestoleciu międzywojennym. Kwart. Pedag. R. 46: $2001 \mathrm{nr} 1$ s. 97-112.

458. WIERZCHOWSKA-KONERA Bożena: Biblioteki, czytelnie, czytelnictwo w lubelskich średnich szkołach ogólnokształcących w okresie międzywojennym. [W:] Lublin a książka. Materiały z konferencji naukowej zorganizowanej z okazji 50-lecia Wydziału Humanistycznego UMCS i 95-lecia Biblioteki im. H. Łopacińskiego w Lublinie. Pod red. Antoniego Krawczyka, Elżbiety Józefowicz-Wisińskiej. Lublin 2004 s. 599-608. 


\title{
VI. DZIEJE RUCHU NAUCZYCIELSKIEGO
}

\author{
1. Opracowania ogólne
}

459. CHRANIUK Ryszard: Działalność ZNP w Siedlcach na rzecz utrwalenia pamięci historycznej dotyczącej oświaty na Podlasiu. Szkice Podlaskie. Z. 12: 2004 s. 101-103.

$\mathrm{XX}$ w.

460. DĄBROWA Marian: Na wiedeńskim bruku (w dziewięćdziesiątą rocznicę utworzenia Komitetu Polskiego Nauczycielstwa Galicyjskiego w Wiedniu). Prz. Hist.-Ośw. R. 47: 2004 nr 3/4 s. 233-235.

461. MAŁEK Józef: Sekcja emerytów i rencistów przy Oddziale Związku Nauczycielstwa Polskiego w Jarosławiu. Rocz. SMJ. T. 15: 2002/2004 [druk.:] 2004 s. 217-230.

$\mathrm{XX} w$.

462. PYSZKO Stanisław: Oświata i związki nauczycielskie w powiecie chełmskim w latach 1915-1939. Chełm 2004 Zw. Nauczycielstwa Pol. Oddz. w Chełmie ss. 273, nlb. 2, il.

463. WIADEREK Wioletta: Integracyjna działalność związku zawodowego na Uniwersytecie Jagiellońskim. Prz. Hist.-Ośw. R. 47: 2004 nr 3/4 s. 225-231.

Od $1981 \mathrm{r}$.

\section{Pamiętniki nauczycieli}

464. BRANDT Jadwiga von: Jakby wczoraj. Wspomnienia $z$ Wojsławic i Chełma. Chełm 2004 Chełmska Bibl. Publ. ss. 155, il.

Wspomnienia $z$ dzieciństwa w Wojsławicach, objęcia w 1937 r. posady naczelniczki tamtejszej poczty, wstapienia w 1942 r. do AK, aresztowania w 1945 r. przez UB, rozpoczęcia w 1956 r. wieloletniej pracy nauczycielki języka niemieckiego.

465. BRZEZIŃSKI Władysław: O ojców mowę. Oprac. Jadwiga Brzezińska. Koszalin 2003 Puls ss. 392, il.

Wspomnienia nauczyciela, wykładowcy Wyższej Szkoły Pedagogicznej w Słupsku, badacza gwary krajenskiej, żyjącego w l. 1922-1998, obejmujące dzieciństwo w położonej po niemieckiej stronie Podróżnej, naukę w polskich gimnazjach w Bytomiu i Kwidzynie, działalność w Związu Polaków w Niemczech, wojenny pobyt w Starej Korytnicy, dalszą naukę w liceum w Zlotowie, studia polonistyczne na UAM, prace w oświacie i na uczelni; uzupełnione dokumentami dotyczącymi autora i relacjami osób mu bliskich.

466. ChLUDZIŃSKA-BADYDA Anna Maria: Szkoła numer sześć. Ziemia Lomżyńska. [R.] 8: 2004 s. $313-317$.

Wspomnienia późniejszej nauczycielki opisujące początki swojej edukacji w szkole powszechnej w Łomży od grudnia 1935 r. do czerwca 1941 r.

467. GRYCZAN Tadeusz: Osiemdziesiąt lat mojego życia. Pod red. Janusz Kopcial. Suwalki 2003 Hańcza ss. 77, nlb. 1, il., mapa. (Żyć we Wspomnieniach).

Pamiętnik pochodzącego z rodziny chłopskiej pedagoga (ur. w 1923 r.) $-z$ dzieciństwa i nauki w Kurejewce i Grajewie, aresztowania 4 VI 1943 r. i pobytu w obozach Majdanek, Natzweiler, Dachau, Neuengamme i Sand Posten, rekonwalescencji w Szwecji i działalności nauczycielskiej w Radzilowie i Kroszewie, studiów na Uniwersytecie Gdańskim oraz pracy jako dyrektor domu dziecka w Olecku w l. 1955-1991. 
468. JANCEWICZ Zofia: Rok szkolny 1945/1946 w Janowcu nad Wisłą. Notatnik Janowiecki. Nr 13: 2003/2004 [dr.:] 2004 s. 197-199.

Wspomnienia nauczycielki szkoły podstawowej i kursów dla dorosłych.

469. KOSIK Eugeniusz: W świętokrzyskim piekle. Dzienniki nauczyciela Politechniki Świętokrzyskiej w Kielcach prowadzone w okresie 1991-2001. Kielce-Mniów 2002 Urząd Gminy ss. 344 , il., mapa. skim.

Wspomnienia i refleksje autora (ur. 1940) na temat życia i ludzi w Ziemi Świętokrzyskiej i Opolu Lubel-

470. KROPIWNICKI Jan: Okruchy belferskiego życia. Jelenia Góra 2003 Wydaw. Nauczycielskie ss. 160. (Przewodnik Nauczyciela).

Wspomnienia z pracy w szkole i we władzach oświatowych.

471. NIEDZIALKOWSKA Zofia: Moja wycieczka w przeszłość 1914-2004. Pod red. Dorota Korokozowicz, Czesław Parzych; wstęp Jadwiga Nowicka, Janusz Golota. Ostrolęka 2004 Tow. Przyj. Ostrołęki, Ostrolęckie Tow. Nauk. im. Adama Chętnika ss. 24.

Wspomnienia nauczycielki historii (1904-1991), badaczki dziejów Ostrołęki, opisujące życie i naukę w mieście, jej kontynuację w Łomży i w Warszawie, pracę w magistracie Ostrołęki oraz naukową w stolicy, tajne komplety w czasie II wojny światowej oraz powojenną działalność pedagogiczną w Zdunach i Łowiczu doprowadzone do $1986 \mathrm{r}$.

472. OSTROMĘCKA Jadwiga: Pamiętnik z lat 1862-1911. Oprac. Anna Brus. Warszawa 2004 DiG ss. 350, il. Inst. Historii PAN.

Wspomnienia nauczycielki (1862-1944/45) w Kazaniu o życiu kolonii polskiej, a następnie po podjęciu pracy w Warszawie (1902 r.) - o działaczach oświatowych i przyjaźni z Elizą Orzeszkową.

473. SMORODINOV Vasilij Grigorevič: Moja służba w Warszawskim Okręgu Naukowym i zdarzenia ze szkolnego życia. Wspomnienia pedagoga. Oprac. Wiesław Caban; wstęp i przypisy W. Caban i Beata Drozdowska; tł. B. Drozdowska. Kielce 2003 Wydaw. Akad. Świętokrzyskiej ss. 263 , nlb. 1 , il.

Wspomnienia nauczyciela rosyjskiego (1841-1917), ukazujące pracę w szkołach Królestwa Polskiego - od 1867 r. w Koninie, Kaliszu, Piotrkowie, od 1873 r. w Radomiu, od 1883 r. jako dyrektora tamtejszego gimnazjum; zarazem opisujące życie społeczności rosyjskiej wśród Polaków.

Rec.: Walewander Edward, Lub. Rocz. Pedag. T. 24: 2004 s. 355-357; Walewander E., Studia Polonijne. T. 25: 2004 s. 282-284.

474. TREMBIŃSKI Tadeusz: Martyrologia nauczycieli z pow. łomżyńskiego (1941-1945). Ziemia Lomżyńska. [R.] 8: 2004 s. 281-307.

Wspomnienia.

\section{Z ŻYCIA I DZIALALNOŚCI ORGANIZACJI MLODZIEŻOWYCH}

475. BOGU, Polsce, bliźnim... 90 lat polskiego harcerstwa. Materiały z sesji historyczno-naukowej 19 maja 2001 r. w Rzeszowie zorganizowanej przez Podkarpacki Okręg ZHR. Pod red. Adama F. Barana. Kraków 2004 Drukarnia GS; na zlec. Podkarpackiego Okręgu ZHR ss. 141, sum.

Z treści: Zalotyński Marek: Wstęp s. 11-15; Kozimala Irena: Początki skautingu w Galicji 1911-1920 (wybrane aspekty) s. 16-32; Żychowska Maria: Jerzy Braun (1901-1975) - animator kultury harcerskiej s. 33-47; Danel Jacek K.: Harcmistrz Kazimierz Sabbat i jego działalność harcerska s. 48-73; Hausner Wojciech: Rodowód niepokornego harcerstwa (1944-1989) s. 74-83; Baran A. F.: Geneza i organizacja struktur ZHR w Polsce południowo-wschodniej (1989-1993) s. 84-108; Adamski Stefan: Harcerstwo poiskie na Ukrainie s. 132-138. 
476. BRONIEWSKI Stanisław, pseud. Orsza: Trójka. Zapiski o ludziach i wydarzeniach z dziejów 3 Warszawskiej Drużyny Harcerzy im. Xięcia Józefa Poniatowskiego. Wyd. Marian Szczęśniak. Warszawa 2004 Zarząd Gł. Stow. Szarych Szeregów ss. 109, nlb. 2, il.

477. BUCZKOWSKA Karolina: Z dziejów turystyki harcerskiej w Poznaniu w latach 1912-1956. Rocz. Nauk. AWF. Z. 53: 2004 s. 109-124, sum.

478. DOBROŃSKI Adam, Dobroński Aleksander, Dworakowski Jan: Początki harcerstwa w Białymstoku 1913-1923. Białystok 2003 Komenda Hufca ZHP im. hm. Stanisława Moniuszki; PTH. Oddz. ss. 96, il. Hufiec Białystok. Zw. Harcerstwa Pol. (Harcerskim Tropem. T. 1).

479. GAJDOWSKI Leon: Harcerstwo grajewskie 1919-1945. Oprac. red. i uzup. Tomasz Dudziński. Grajewo 2004 Tow. Przyj. 9 PSK ss. 141, il.

480. GŁOWACKA-SOBIECH Edyta: W rocznicę śmierci Olgi i Andrzeja Małkowskich - twórców polskiego skautingu. Biul. Hist. Wych. $2004 \mathrm{nr} 1 / 2$ s. 39-42.

481. JAROS Tadeusz: W służbie Bogu i Polsce. Z kart historii harcerstwa w Pruszkowie w latach 1911-1939. Pruszków 2004 Stow. Szarych Szeregów. Krag im. Aleksandra Kamińskiego; Pow. i Miej. Bibl. Publ. im. H. Sienkiewicza ss. 280, il.

482. KALISZ Jan: Harcerstwo hrubieszowskie 1918-1939. Hrubieszów-Lublin 2004 Polihymnia ss. 181, il. (Biblioteka Towarzystwa Regionalnego Hrubieszowskiego. T. 37).

483. KŁOS Zofia: Kronika XII Gdyńskiej Drużyny Harcerzy im. Andrzeja Małkowskiego. Gdynia-Grabówek 1945-1949. Gdynia 2004 Reklama ss. 201, il.

484. KOBENDZA Ryszard Lucjan: Harcerstwo w Piotrkowskim Gimnazjum i Liceum im. Bolesława Chrobrego. IV Drużyna Harcerska im. Cypriana Godebskiego, Harcerski Klub Sportowy „Skaut”, Tajna Organizacja ZHP „Mała Dywersja”, 15 Drużyna Starszoharcerska, 23 Harcerska Drużyna Jęzkowa. Gorzów Wielkopolski 2002 Pol. Tow. Nauk. Kultury Fizycznej. Oddz. w Gorzowie Wielkopolskim; Piotrkowskie Tow. Przyj. Nauk ss. 100, nlb. 2, tabl. 2.

485. KORPAK Janusz: Zarys historii Miejskiego Hufca ZHP w Nowym Sączu w latach 1945-1949. Rocz. Sqdecki. T. 32: 2004 s. 255-279.

486. KOWALCZYK Bogusław: „Bemacy” w służbie harcerstwa i ojczyzny. Dzieje 16 Poznańskiej Drużyny Harcerzy im. gen. Józefa Zachariasza Bema w latach 1920-2000, powstałego Szczepu Harcerskiego im. hm. Franciszka Firlika oraz Harcerskiego Kręgu Szesnastaków „Bemak”. Cz. 3: Lata odrodzeń, wzlotów, pogrążeń i deformacji czyli o Drużynie Poznańskich Bemaków i jej członkach harcerek i harcerzy zrzeszonych w szczepie im. hm. Franciszka Firlika od zakończenia II wojny światowej do lat sześćdziesiątych i w dalszym czasie harcerskich przeobrażeń po rok 2000. Poznań 2003 [B.w.] ss. XII, 435, tabl. 12. ZHP. Komenda Hufca Harcerskiego „Piast” im. Powstańców Wielkopolskich 1918/1919, Poznań-Stare Miasto, Harcerski Krąg Szesnastaków „Bemak”. (Biblioteczka Harcerskiego Kręgu Szesnastaków „Bemak”).

Cz. 1. 1990.

487. KRĘŻEL Janusz: Organizacja Młodzieży Harcerskiej „Watra” w Mielcu 1944-1945. Rocz. Miel. T. 6: 2003 [druk.:] 2004 s. 115-135.

488. KULIŃSKA Lucyna: Związek Akademicki „Młodzież Wszechpolska” i „Młodzież Wielkiej Polski” w latach 1922-1947 (struktury, funkcjonowanie i główni działacze). Wyd. 2. Warszawa 2004 Inicjatywa Wydawnicza „Ars Politica” ss. 125.

Wyd. 1. Kraków 2000. 
489. MALOLEPSZY Eligiusz: Kultura fizyczna w działalności wiejskich organizacji młodzieżowych II Rzeczypospolitej. Częstochowa 2004 Wydaw. Akad. im. Jana Długosza ss. 242, nlb. 2, tabl. 8, sum., Zsfg.

490. MALOLEPSZY E.: Kultura fizyczna w programach działalności Centralnego Związku Młodzieży Wiejskiej w latach 1919-1928. [W:] Wkład nauk humanistycznych do wiedzy o kulturze fizycznej. T. 1: Historia kultury fizycznej. (Studia i szkice). Red. nauk. Tadeusz Rychta, Jerzy Chełmecki. Warszawa 2003 s. 135-142.

491. METODA zuchowa Aleksandra Kamińskiego [1903-1978] - tradycja i teraźniejszość. Materiały z konferencji Warszawa-Stara Dąbrowa 14-16.11.2003. Oprac. i red. Adam Czetwertyński, Halina Jankowska. Warszawa 2004 Horyzonty ss. 84, il.

Z treści: Czarnota Wanda: Aleksander Kamiński „Kamyk”- czlowiek renesansu s. 9-17; Borodzik Andrzej: Tego nie zobaczycie na wystawie s. 19-22; Wieczorek Teresa: Wilczki i zuchy przez pierwsze dwadzieścia lat ruchu harcerskiego s. 23-26; Dębski Franciszek: Społeczne tho tworzenia metody zuchowej przez Aleksandra Kamińskiego s. 27-32; Wlodarska-Karwecka Róża: Rozwój ruchu zuchowego w Warszawie w dwudziestoleciu międzywojennym s. 33-41; Wardęcki Marek: Aleksander Kamiński i zuchy po Zjeździe Łódzkim s. 53-66.

492. MILESKA Maria Irena: Materiały do historii krakowskiego harcerstwa żeńskiego w latach 1911-1939. T. 2. Oprac., uzup. i red. Janusz Wojtycza. Kraków 2004 Barbara - B. Gąsowska; Komisja Hist. Krakowskiej Choragwi ZHP ss. 352, tabl. 2, mapa.

T. 1. 2003.

493. MY z Zetempe..." Upadek i likwidacja Związku Młodzieży Polskiej (1955-1957). Oprac. Marek Wierzbicki. Warszawa 2004 ISP PAN ss. 178. Inst. Studiów Polit. PAN. (Dokumenty do Dziejów PRL. Z. 17).

494. NOWACKI Tadeusz: ZET - wychowawca. Prz. Hist.-Ośw. R. 47: 2004 nr 3/4 s. 21-40.

495. NOWAK Tomasz: Harcerstwo na Ziemi Sochaczewskiej. Sochaczew 2003 Komenda Hufca Ziemi Sochaczewskiej ss. 68 , il.

496. PATECKI Andrzej: Katolickie Stowarzyszenie Młodzieży Żeńskiej „Tęcza” i Katolickie Stowarzyszenie Młodzieży Męskiej w Topoli Małej w latach 1933-1950. [W:] Topola Mała wczoraj i dziś. 1404-2004. Praca zbiorowa. Pod red. Jadwigi Krzyślak. Ostrów Wielkopolski-Topola Mała 2004 s. 57-67.

497. PIETRZYKOWSKI Marian: Historia harcerstwa wielkopolskiego. T. 1: 1912-1920 - od skautingu do harcerstwa. Współpr. aut. Zbigniew Pilarczyk, Tomasz Kozik, Janusz Wolski. Poznań 2004 staraniem KHCh ss. 183, il. Zw. Harcerstwa Pol. Komenda Choragwi Wielkopolskiej im. Powstańców Wielkopolskich 1918/19. (Wydawnictwo Komisji Historycznej. Ser. 1. Monografie. [T.] 17).

498. POPIELIŃSKI Paweł: Geneza działalności organizacji młodzieży mniejszości niemieckiej. Rocz. Pol.-Niem. [T.] 11: 2003 [dr.:] 2004 s. 77-93.

Związek Młodzieży Mniejszości Niemieckiej w Polsce, od 1992 r.

499. POTOK Roman: 20-lecie Kręgu Harcerzy Seniorów im. Jana III Sobieskiego w Kościanie (1983-2003). Pam. TMZK. T. 11: 2001/2004 [druk.:] 2004 s. 189-205.

500. SIRVYDIENË Ilona: Organizacje polskiej młodzieży z Litwy studiującej za granica w okresie międzywojennym. Biul. Hist. Pogranicza. Nr 5: 2004 s. 77-81, santr., sum. 
501. SZKICE z historii lewicowego ruchu młodzieżowego na Lubelszczyźnie. Pod red. Emila Horocha. Lublin 2004 Zarząd Woj. Stow. „Pokolenia” ss. 174, il. Pokolenia.

$\mathrm{Z}$ treści: Horoch E.: Z dziejów lewicowych i demokratycznych organizacji młodzieżowych w latach II Rzeczypospolitej (1918-1939) s. 11-21; Kotowski Ryszard: Zwiqzzek Walki Młodych na Lubelszczyźnie w latach 1944-1948 s. 23-42; Szymczyk Anna: Udzial młodzieży w rozwoju gospodarczym Lubelszczyzny (1950-1980) s. 43-75; Pachuta Pawel: Kalendarium organizacji młodzieżowych na Lubelszczyźnie (1943-1995) s. 77-145; Ochyra Stefan: Organizacje młodzieżowe w Wojsku Polskim - działalność i specyfika organizacyjna (ZWM, ZMP, SZMW) (30 VII 1958 - 5 III 1973) s. 147-152; Dwornicki Janusz: „Pokolenia” [stowarzyszenie, 1. 1993-2003] s. 153-174.

502. Z DZIEJÓW prasy harcerskiej w kraju i na obczyźnie. Tom studiów dedykowany pamięci Zygmunta Lechosława Szadkowskiego (1912-1995). Pod red. Wiesława Kukli i Marka Szczerbińskiego. Gorzów Wlkp 2003 Zamiejscowy Wydz. Kultury Fizycznej poznańskiej AWF w Gorzowie Wlkp ss. 407 , il.

503. ZAWADZKA Anna: Dzieje harcerstwa żeńskiego w Polsce w latach 1911-1948/49. Warszawa 2004 Horyzonty ss. 459 , nlb. 3, il., mapy.

Oprac. Anna Gruca 